
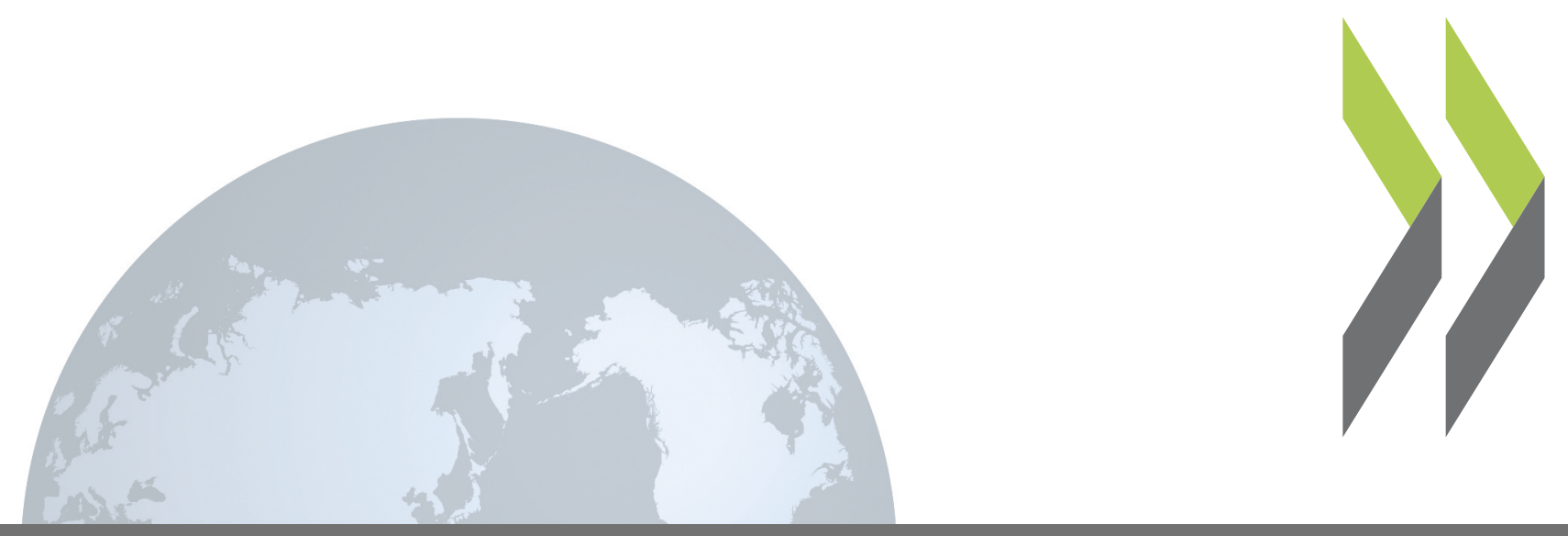

OECD Corporate Governance Working Papers No. 10

\title{
Making Stock Markets Work
} to Support Economic Growth: Implications for Governments, Regulators,

\section{Stock Exchanges,}

\section{David Weild,} Edward Kim, Lisa Newport

Corporate Issuers and their Investors 


\section{OECD CORPORATE GOVERNANCE WORKING PAPERS}

OECD Corporate Governance Working Papers provide timely analysis and information on national and international corporate governance issues and developments, including state ownership and privatisation policies. The working paper series is designed to make select studies by the OECD Corporate Governance Committee, OECD staff members and outside consultants available to a broad audience.

The papers are generally available only in their original language English or French with a summary in the other if available.

The opinions expressed in these papers are the sole responsibility of the author(s) and do not necessarily reflect those of the OECD or the governments of its member countries, unless otherwise noted.

Comment on the series is welcome, and should be sent to either corporate.affairs@oecd.org or the Corporate Affairs Division, OECD, 2, rue André Pascal, 75775 PARIS CEDEX 16, France.

\section{OECD CORPORATE GOVERNANCE WORKING PAPERS}

are published on www.oecd.org/daf/corporateaffairs/wp

\footnotetext{
This document and any map included herein are without prejudice to the status of or sovereignty over any territory, to the delimitation of international frontiers and boundaries and to the name of any territory, city or area.

(C) OECD 2013

Applications for permission to reproduce or translate all or part of this material should be made to: OECD Publishing, rights@oecd.org or by fax 33145249930.
} 


\title{
Executive Summary
}

\author{
Making Stock Markets Work to Support Economic Growth \\ - Implications for Governments, Regulators, Stock Exchanges, Corporate Issuers and \\ their Investors -
}

\section{By David Weild, Edward Kim \& Lisa Newport ${ }^{1}$}

This study was originally presented to representatives of the OECD member nations in draft form on 15 April 2013. The objective was to provide critical observations on the state of key global equity markets, with substantive suggestions to improve their efficiency and effectiveness in facilitating capital formation.

We have since received and incorporated significant valuable feedback from the OECD, and this final version of the study has been expanded to cover the top 26 initial public offering (IPO) producing nations, up from the originally examined 13 nations.

We examine, herein, the structure of markets and the characteristics that make some more successful than others, with success defined as providing the most fertile ground for capital raising, effective allocation of capital, job creation and, ultimately, a stronger macroeconomy.

Stock markets in the United States are a particular focus of this report, as we highlight structural and regulatory changes that have been exceptionally harmful to capital formation, as well as recent progress that is being made to improve market structure.

We offer compelling evidence that the primary determinant of long-term sustainability of IPO markets and, as a consequence, an important driver of economic growth, is the relative size of aftermarket economic incentives. Low aftermarket incentives (defined as tick sizes that are less than $1 \%$ of share price for sub USD 500 million market value stocks) and low numbers of small public companies lead to low levels of IPO activity. Broker-dealers, who are the facilitators of capital formation, must have adequate incentives in order to support small company IPO activity. The combination of higher tick sizes and larger numbers of small public companies, on a gross domestic product (GDP) weighted basis, combine to sustain the critical mass infrastructure and services required to support a vibrant domestic IPO market.

\footnotetext{
${ }^{1}$ The authors would like to thank the partners of Grant Thornton LLP for their longstanding support of the authors' research into how capital markets structure impacts capital formation, without which, the JOBS Act in the United States could not have become reality. Grant Thornton's support has allowed us to inform the discussion on "tick sizes" and electronic markets structure in the United States by helping to focus attention on how smaller and smaller trading increments may harm small capitalization stocks and the growth economy, while increasing "short-termism" in large capitalization stocks.
}

In addition, we gratefully acknowledge the interest and support of the OECD and in particular, Mats Isaksson and Serdar Çelik, for asking the questions that need to be asked to help the world's economies provide for a better tomorrow. 
We also find that GDP growth rates alone are, surprisingly, not a major determinant of small company IPO activity. Thus, stock markets that provide significant economic incentives to support small companies and associated infrastructure in the aftermarket will create higher rates of capital formation that, in turn, will generate jobs, economic growth and tax receipts.

In the same way that a city's infrastructure cannot be maintained without adequate capital to support it, an equity market must also be supported with adequate economic incentives in order to maintain vibrancy. The most striking example of how the lack of such incentives can impact a market is the United States. What was once the greatest capital formation engine in the world has been reduced to a shadow of its former productivity, because of the elimination of nearly all of the economics that once fueled the growth of its ecosystem.

Structural and regulatory changes that began with the new Order Handling Rules in 1997 and Regulation Alternative Trading Systems (ATS) in 1998 were the key blows that were the most damaging to the new issue market in the U.S., particularly for small company IPOs. These changes set in motion a dramatic shrinkage in trading spreads and tick sizes in all stocks. While this was, on its face, good news for investors, the ultimate consequences of smaller spreads and tick sizes was manifest in a stark decline in the number of companies going public. Ultimately, there is a paradox at work here: policymakers intent on saving investors' money through lower transaction costs can do more harm than good by undermining the very infrastructure and services required to support economic growth.

Public company listings, which peaked in the U.S. in 1997 with 8823 exchange-listed companies, have nearly been cut in half to only 4916 companies at the end of 2012 - a decline of $44.3 \%$. In fact, since the peak, the U.S. has suffered 15 consecutive years of lost listings.

The U.S. stock markets are essentially governed by a one-size-fits-all regulatory framework, with one-cent tick sizes for every stock, regardless of share price, market capitalization or liquidity. While we are encouraged by the passing of the JOBS Act in April 2012, the U.S. Securities and Exchange Commission, alongside Congress, has much work still to do in order to reverse the damage that has been done.

While the IPO decline is most extreme in the U.S., the world supply of IPOs has also suffered a material decline with the proliferation of electronic markets. Work by the OECD shows that the global number of IPOs has declined from over 2000 per year in the early 1990s to less than 750 IPOs in 2012. Two thirds of this decline comes from outside of the U.S.

Hedge funds and other hyper trading institutions have become the dominant force in the one-cent tick size market, at the expense of long-term fundamental investors and liquidity providers (intermediaries). When trading interests overwhelm fundamental investor interests, price distortions occur, the marketing of individual stocks is displaced by derivatives (including exchange traded funds) and capital formation and allocation become less effective. In turn, economic cycles are made more extreme and long-term economic growth may be stunted. 
One-size-fits-all is a poor basis for regulation. Large cap stocks are inherently liquid and benefit from the interest of many investors looking to buy and sell the stocks at the same time. By contrast, small cap stocks typically are less liquid, with asymmetrical or one-sided order-book markets. Unlike their large cap brethren, small cap stocks require broker-dealers to support liquidity, sales and equity research in order to sustain active markets. One-sizefits-all stock market structures will underperform markets that are optimized separately to meet the needs of large cap and small cap stocks and their respective constituencies.

JEL Classification: G30, G32, G34, G38

Keywords: allocation of capital, corporate governance, equity market structure, initial public offering, stock exchange, tick size 


\section{TABLE OF CONTENTS}

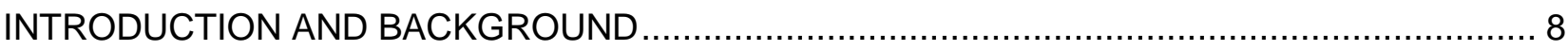

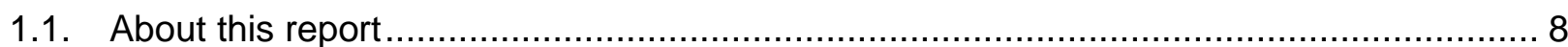

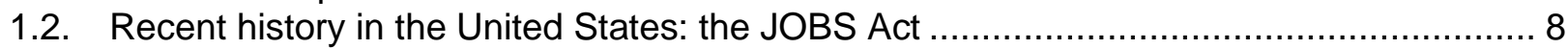

1.2.1. Our involvement in the JOBS Act ............................................................... 9

1.2.2. Dynamics that led to the JOBS Act ............................................................. 10

1.2.3. How ideologies undermine markets: are we increasing systematic and

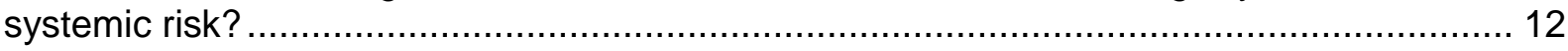

STOCK MARKET STRUCTURE IN THE UNITED STATES.......................................... 15

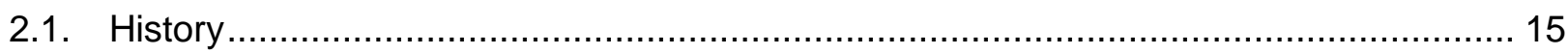

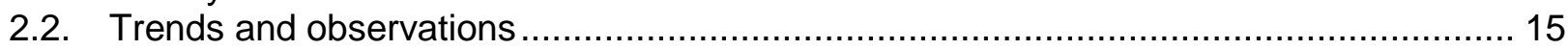

2.2.1. Economic incentives ("tick sizes" and commissions) .................................. 15

2.2.2. Why tick sizes are critical in electronic markets.......................................... 17

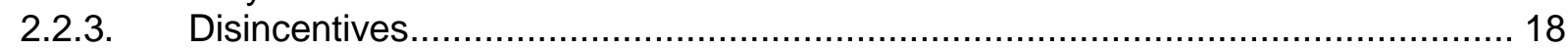

2.2.4. Symmetrical versus asymmetrical markets .............................................. 20

2.2.5. Quality of the price discovery process in the new market structure ..................... 20

2.2.6. Primary (equities) versus secondary (derivatives) trends and effects ..................21

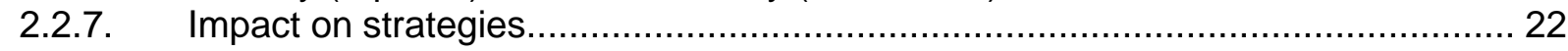

IPO MARKETS (U.S. AND ABROAD) AND LISTINGS ….......................................... 26

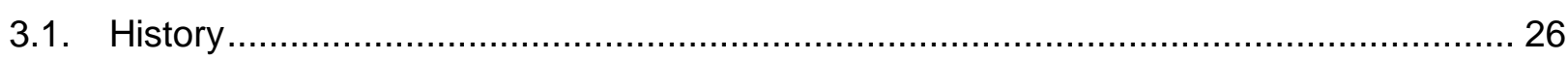

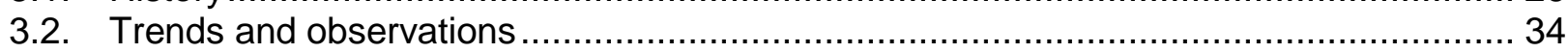

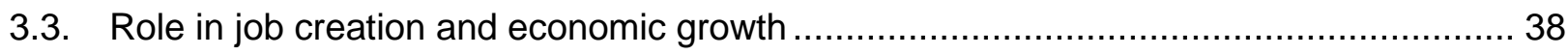

3.3.1. Direct job formation and the multiplier effect .............................................. 38

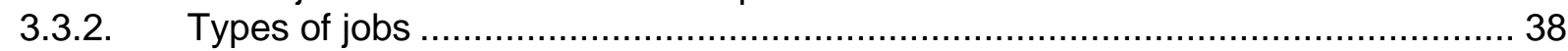

3.3.3. Alternative ways to raise capital and their impact on growth ............................. 39

KEY FACTORS IN EFFECTIVE STOCK MARKETS (SUPPORTING ECONOMIC GROWTH

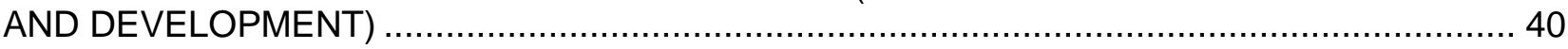

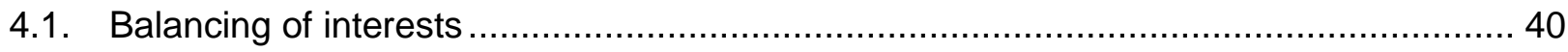

INITIATIVES IN OTHER AREAS OF THE WORLD-OUR TAKE AND WORDS OF

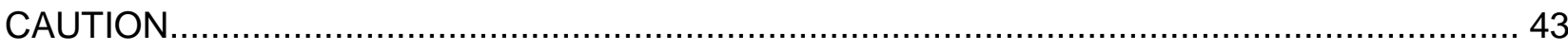

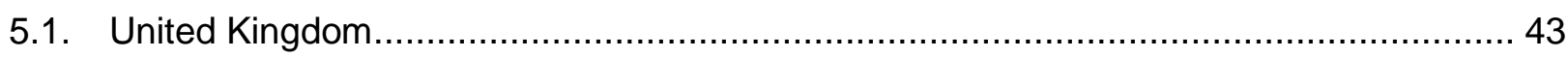

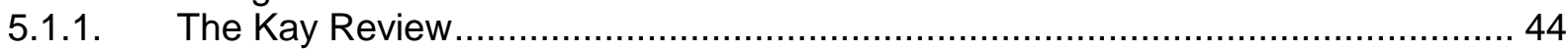

5.1.2. The Government Response to the Kay Review........................................... 44

5.1.3. BIS Initiative on making companies more accountable to shareholders and the

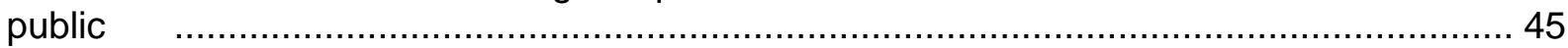

5.1.4. Foresight Project on the future of computer trading in financial markets .............. 45

5.1.5. Bold action to open up London's equity markets to high-growth companies........ 46

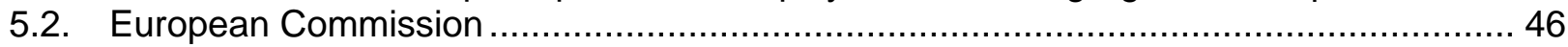

5.2.1. Review of the Markets in Financial Instruments Directive ............................... 46

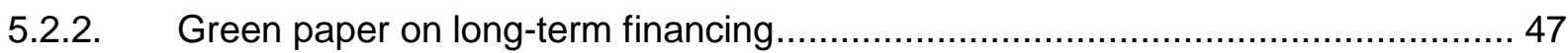

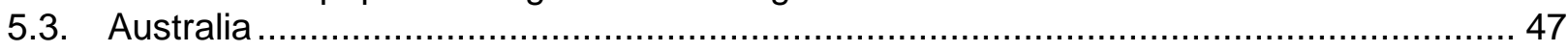


5.3.1. Consultation on key market structure reforms ........................................... 47

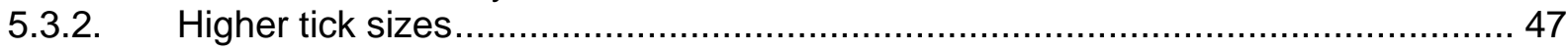

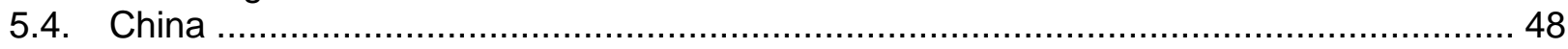

5.4.1. To develop a more open and inclusive capital market..................................... 48

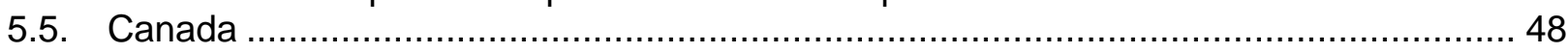

5.5.1. Consultation on electronic trading and direct electronic access to

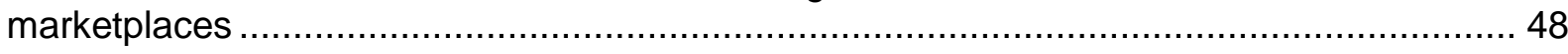

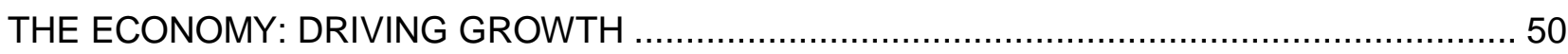

6.1. What changes stimulate or depress equity capital formation .................................. 50

6.1.1. Some factors that impact stock market based economic activity ........................ 51

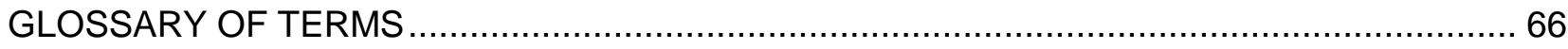

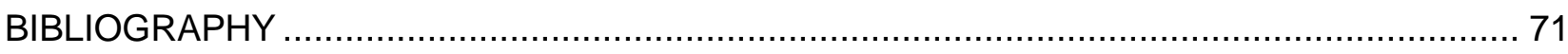

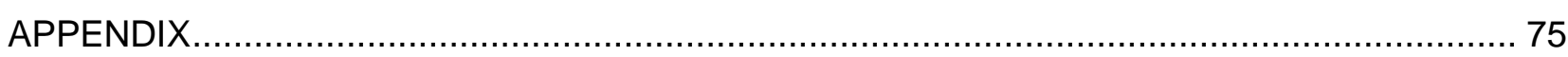




\section{INTRODUCTION AND BACKGROUND}

\subsection{About this report}

This report is a project of the OECD and is made to the OECD Corporate Governance Committee, which seeks to promote a sound and competitive business environment. Effective capital markets are critical to this objective. The report is directed to governments, regulators, stock exchanges, corporate issuers and investors. The intent is to help policymakers better lay the groundwork for long-term sustainable growth through properly designed capital markets that are likely to improve investment activity, efficient allocation of capital, capital formation, innovation, job creation and tax receipts.

\subsection{Recent history in the United States: the JOBS Act ${ }^{2}$}

The JOBS Act (Jumpstart Our Business Start-up Act) was arguably the most significant change to United States federal securities laws for developing companies in modern history. It substantially changed an array of laws and regulations with the intent to make it easier for companies to go public, while also making it easier for companies to raise capital privately and stay private longer. It was also intended to reduce cost and make it easier for newly public companies to comply with U.S. Securities and Exchange Commission (SEC) reporting requirements during their first few years as public companies. Finally, under Title 1 Section 106(b), entitled "Tick Sizes," the Act mandated that the SEC study the impact of decimalization on the number of initial public offerings (IPOs) and issue a report to the U.S. Congress within 90 days of the enactment of the Act. That report to Congress ${ }^{3}$ was issued in July 2012 and essentially concluded, after a broad review of the academic literature, that further study was needed. To that end, the SEC subsequently held a "Roundtable on Decimalization" to solicit a wide range of views and consider how a pilot study, to increase tick sizes, might be constructed. One of the co-authors of this paper participated in that roundtable discussion. ${ }^{4}$

In our view, this report provides compelling evidence that the relative size of aftermarket economic incentives, as evidenced by tick size as a percent of share price in smaller public companies, is likely a primary determinant of the size and sustainability of IPO markets (and with them, economic and job growth) generally, and that the United States stock markets provide structurally inadequate incentives to sustain IPO issuance at acceptable and competitive levels. Furthermore, this report demonstrates that countries whose markets do

\footnotetext{
${ }^{2}$ For a copy of the JOBS Act, see http://www.gpo.gov/fdsys/pkg/BILLS-112hr3606enr/pdf/BILLS$112 \mathrm{hr} 3606 \mathrm{enr} . \mathrm{pdf}$.

${ }^{3}$ The U.S. Securities \& Exchange Commission Report to Congress on Decimalization can be found at http://www.sec.gov/news/studies/2012/decimalization-072012.pdf.

${ }^{4}$ See SEC Roundtable on Decimalization topics for discussion at http://www.sec.gov/news/press/2012/2012274.htm and see co-author Weild's submission for the Roundtable at http://www.sec.gov/comments/4657/4657-6.pdf.
} 
provide higher aftermarket economic incentives on smaller cap stocks generally enjoy stronger IPO markets.

\subsubsection{Our involvement in the JOBS Act}

Most market participants were taken by surprise by the seeming suddenness with which the JOBS Act appeared and was signed into law in the U.S. HR 3606 was passed in the U.S. House of Representatives on 8 March 2012, and then passed by the U.S. Senate with only an amendment to Title III or the so-called "Crowdfunding Provision of the Act." It was then sent back to the House for an "up or down vote," where it passed on 27 March 2012. The Act was signed into law on 5 April 2012, by President Barack Obama in a ceremony in the Rose Garden of the White House, which was attended by one of the authors.

In fact, the history and gestation of the JOBS Act was much longer, likely starting with the publication of two studies by the authors (Weild \& Kim) in 2008 and 2009 that caught the attention of the press, a U.S. Senator, ${ }^{5}$ some in U.S. House of Representatives ${ }^{6}$ and the White House (through the U.S. Office of Science and Technology Policy). ${ }^{7}$ These studies helped convince many that United States IPO markets were deeply and systemically troubled, and that the decline in U.S. IPOs was not, as many on Wall Street had suggested, due to "market cycles," but rather to the effects of regulatory and structural changes that date back to the 1990s. Some of the recommendations ${ }^{8}$ from these studies informed a wide variety of titles to the JOBS Act, including the formation of the new category of "Emerging Growth Company" issuer in the United States (see citations of the authors in the IPO Task Force Report to the U.S. Treasury).

In November 2008, the first study, Why are IPOs in the ICU?, was published by Grant Thornton LLP. It demonstrated two previously unrecognized and highly disturbing facts: First, that the small IPO market in the United States, defined as IPOs raising less than USD 50 million, declined abruptly in 1998 and never recovered, and second, that this decline in the small IPO market took place a full two years before "decimalization" (when the United States began trading stocks in one penny increments) and three years before the muchcriticized Sarbanes-Oxley Act of 2002.

In November 2009, a full year later, A wake-up call for America was published by Grant Thornton LLP. This study documented the percent change in the number of listed companies

\footnotetext{
${ }^{5}$ On 16 December 2009, U. S. Senator Ted Kaufman, in a speech on the floor of the U.S. Senate, Senator Kaufman cited the Grant Thornton study by Weild \& Kim, "A wake up call for America" and pointed to the loss of the U.S. IPO market, decline in listings and the impact on jobs. He concluded his speech by stating, "How can we create a market structure that works for a USD 25 million IPO - both in the offering and the secondary aftermarket. If we can answer that question, Mr. President, this country will be back in business."

${ }^{6}$ See letter dated 22 March 2011, sent by Chairman Issa of the House Oversight Committee to Securities \& Exchange Commission Chairman Mary Schapiro at http://democrats.oversight.house.gov/images/stories/FULLCOM/510\%20future\%20of\%20cap\%20form/2 011-03-22\%20DEI\%20to\%20Schapiro-SEC\%20-\%20capital\%20formation\%20due\%204-5.pdf. The first two citations in this letter are for Market structure is causing the IPO crisis - and more by Weild and Kim.

${ }^{7}$ On 8 September 2011, President Obama signaled his support by stating in a speech to a joint session of Congress that "We're also planning to cut away the red tape that prevents too many rapidly growing startup companies from raising capital and going public." See full text of speech at http://www.whitehouse.gov/the-press-office/2011/09/08/address-president-joint-session-congress.

${ }^{8}$ Individual titles of the JOBS Act adopted forms of recommendations made in "A wake up call for America" including the authors recommendation to rescind the prohibition against general solicitation in private placements and to increase the number of shareholders permitted before companies were required to.
} 
for seven major stock markets (Hong Kong, China; Australia; Toronto; Tokyo; Borsa Italiana; London and the United States). It showed that the United States listed stock markets (excluding OTC) was losing listed companies every single year from its peak in 1997. By year end 2012, the United States stock market had experienced 15 consecutive years of declines in listed companies: a 44\% reduction in the population of listed companies on the combined NYSE, NASDAQ and AMEX (acquired by the NYSE) stock markets from 1997 to year end 2012.

The authors have subsequently focused on the period leading up to decimalization, which itself occurred in 2001. We discovered that, in fact, the steepest drop off in the small IPO market, one from which the U.S. IPO market never recovered, occurred in 1998, when primarily quote-based markets were converted to electronic order book markets under Regulation Alternative Trading Systems (Regulation ATS). This rule, and its 1997 precursor (the Order Handling Rules), caused a collapse in dealer incentives from as much as 25 cents per share to 3.125 cents per share - or as much as an $87.5 \%$ decline. Notably, these major changes in U.S. stock market structure were implemented without any kind of pilot study.

\subsubsection{Dynamics that led to the JOBS Act}

An insider's view: the White House, Congress and the SEC

Beginning in June 2009, President Obama began to outline in policy speeches a vision for health care reform in the United States. This kicked off a period of highly partisan debates that consumed Congress and the U.S. media, culminating on 23 March 2010, when President Obama signed The Patient Protection and Affordable Care Act (PPACA), into law. With the PPACA now law, Congress shifted its focus to the job market. The decade of the 2000s showed a decline in non-farm payrolls of over 1.5 million jobs. This stood in stark contrast to each of the prior three decades, where nearly 20 million non-farm jobs were created (19.6 million in the 1970s, 18.3 million in the 1980 s and 21.6 million in the 1990s). ${ }^{9}$ Indeed, even prior to the Credit Crisis in 2008, a period of rising stock prices and rapid growth in real estate construction, job creation ran at only half of historical rates. The release of the June 2010 study, "Market structure is causing the IPO crisis-and more" ${ }^{\text {"10 }}$ in which the "-and more" linked the lackluster IPO market to the lackluster job market, found interest in all three branches of the U.S. government.

\section{Competing interests}

Washington, D.C., is dominated by an array of competing lobbying interests who are intent upon advancing their own self-interests. At times of crisis, as in the period in the wake of the Credit Crisis, Congress may find it easier to come together and ignore special interests as was the case, we believe, leading up to the passage of The JOBS Act legislation that was generally drafted by the Republican-controlled U.S. House of Representatives, but had the early support of the Democrat-controlled White House.

\footnotetext{
${ }^{9}$ Source Data: U.S. Federal Research Economic Data (FRED) Data Base, Data Series: PAYEMS.

${ }^{10}$ See Weild, D. and E. Kim (2010), "Market structure is causing the IPO crisis—and more", Capital Markets Series, Grant Thornton LLP, www.gt.com/staticfiles/GTCom/Public\%20companies\%20and\%20capital\%20markets/Files/IPO\%20crisi s\%20-\%20June\%202010\%20-\%20FINAL.pdf.
} 


\section{Investors versus traders}

Long-term investors conduct research and value securities on the basis of a forwardlooking assessment of the prospects for a company, industry or sector of the economy. Through the conduct of this strategy, investors add information to the market and aid in price discovery and efficient capital allocation. The investor model is comparatively labour intensive and thus generally requires a higher cost-structure to sustain. Short-term traders, by contrast, conduct little to no research, mine historical information (extract information) and thrive in low-transaction cost, computer based markets.

Policy concern: When trading interests overwhelm fundamental investor interests, proper pricing can cease to occur, capital formation and allocation becomes less efficient (distorted) and economic cycles are made more extreme (capital becomes too inexpensive or expensive). Individual company stock prices are either undervalued or overvalued. The result is that long-term economic growth may be stunted.

\section{Primary (cash equities) versus secondary (derivatives)}

Primary securities are those that raise capital for corporations-be they offerings of stocks, bonds, preferred stock or convertible instruments. The proper pricing and demand for these securities is essential to the financing of corporations, which in turn results in economic and job growth. By contrast, secondary securities or so-called "derivatives" include everything that is not issued by a corporation. Examples might include futures, options, exchange traded funds (ETFs), closed-end funds, collateralized debt obligations (CDOs), collateralized loan obligations (CLOs), mortgage-backed securities and credit-default swaps. The Commodity Futures Modernization Act of 2000 proliferated derivatives by voiding socalled "bucket-shop" 11 laws in the United States. Derivatives markets require careful management of settlement and counterparty risk so as to avoid the risk of default (as seen in the Credit Crisis, when the world may have narrowly averted an economic depression).

Policy Concern: Derivatives may siphon capital flows from primary markets and dominate the pricing of primary securities, thus interfering with capital formation and economic and job growth. The proliferation of derivatives, due to complexity and leverage, has historically been associated with notable catastrophic market failures, including the Savings \& Loan Crisis in the United States (1980s) and the Credit Crisis (2008). Finally, derivatives exchanges have been much more profitable than traditional stock markets, and, as a result, may be likely to acquire stock exchanges, which may further disenfranchise corporate issuers.

\section{Large cap versus small cap}

Large capitalization (and big brand) stocks are structurally dissimilar from small capitalization (little known) stocks. Large cap stocks are inherently liquid, benefit from the socalled network effect ${ }^{12}$ and have so-called "symmetrical" order-book markets where at any point in time, many investors are looking to buy the stock at the same time that many investors will be looking to sell the stock. The vast majority of institutional investor focus (and knowledge) is derived from trading in large- and mid-cap stocks. In fact, U.S. stocks over

\footnotetext{
${ }^{11}$ See "Glossary of Terms" for a definition.

12 lbid.
} 
USD 2 billion in market value currently represent in excess of $93 \%$ of the total listed market value, but less than $20 \%$ of the number of listed companies. By contrast, small capitalization stocks have so-called "asymmetrical" order-book markets where at any point in time, there is generally not a large seller of the stock available to offset a large buyer of the stock or vice versa. Large cap stocks generally are not benefited by active market making that requires capital commitment, sales and research support from the broker-dealer community. For small-cap stocks, capital to support liquidity, sales and equity research may be essential to sustain active markets.

Policy Concern: Given the radically different intrinsic nature of markets for large cap and small cap stocks, it would be logical that these markets should be designed very differently. One-size-fits-all stock market structures will underperform markets that are optimized separately to the needs of large cap and small cap stocks and their respective constituencies. In addition, policymakers must not draw conclusions about market data from indices that skew large cap, e.g., the S\&P 500, FTSE 100, Hang Seng, Nikkei, CAC 40 or the DAX. Even so-called small-capitalization indexes, such as the Russell 2000 in the United States, frequently skew to higher than median equity market value for listed companies and thus provide a highly misleading picture of market quality in the smallest deciles (all companies start small).

\subsubsection{How ideologies undermine markets: are we increasing systematic and systemic risk?}

Both "systematic risk" and "systemic risk" have been elevated ${ }^{13}$ by the combination of automation and cross-linking of markets, low cost trading (information mining displaces fundamental investing and increases short-termism) and growing emphasis on derivatives (relative to primary securities). On the one hand, we have witnessed elevated "systematic risk" (see definition below), as industries and stocks increasingly trade in a more correlated fashion (especially in times of stress).

On the other hand, the Financial Crisis of 2007-2008, which precipitated what some refer to as the Lesser Depression or Great Recession, and the Flash Crash in the United States, showed evidence of how abrupt moves in one area of markets can precipitate reactionary waves throughout the rest of the world, which can be highly detrimental to investor confidence. Even the RMS Titanic had 16 watertight compartments, of which 5 buckled, filling her with water and driving her to the bottom of the sea. World capital markets are increasingly less siloed, more highly interconnected and thus may be sailing with fewer and fewer "watertight compartments."

Even Arthur Levitt, ${ }^{14}$ who served as SEC Chairman from 1993 to 2001, expressed concerns recently when he said, "The irony of all this is that the change in Order Handling Rules [in 1997] that were instituted under my watch has resulted in the proliferation of markets, technologies and automation that brought about the flash crash and yesterday's [Knight Securities] events. I think public confidence is severely shaken by things of this kind."15

\footnotetext{
${ }^{13}$ See JP Morgan (2011), Rise of cross-asset correlations, 16 May, http://www.cboe.com/Institutional/JPMCrossAssetCorrelations.pdf.

${ }^{14}$ For a biography of Arthur Levitt, see http://en.wikipedia.org/wiki/Arthur Levitt.

${ }^{15}$ From Bloomberg Surveillance with Ken Pruitt and Tom Keen, 2 August 2012.
} 


\section{Definitions}

\section{Systematic risk}

"In finance and economics, systematic risk (sometimes called aggregate risk, market risk, or un-diversifiable risk) is vulnerability to events which affect aggregate outcomes such as broad market returns, total economy-wide resource holdings, or aggregate income. In many contexts, events like earthquakes and major weather catastrophes pose aggregate risks - they affect not only the distribution, but also the total amount of resources. If every possible outcome of a stochastic economic process is characterized by the same aggregate result (but potentially different distributional outcomes), then the process has no aggregate risk." 16

\section{Systemic risk}

"In finance, systemic risk is the risk of collapse of an entire financial system or entire market, as opposed to risk associated with any one individual entity, group or component of a system. It can be defined as "financial system instability, potentially catastrophic, caused or exacerbated by idiosyncratic events or conditions in financial intermediaries." It refers to the risks imposed by interlinkages and interdependencies in a system or market, where the failure of a single entity or cluster of entities can cause a cascading failure, which could potentially bankrupt or bring down the entire system or market. It is also sometimes erroneously referred to as systematic risk." 17

Notable ideologies ("too much of anything is bad for you")

\section{The drive to save investors' money}

In the U.S., some consumer advocates, politicians and regulators have embraced a view that competition resulting in lower and lower transactions costs is beneficial to consumers. However, this is overly simplistic and dangerous. As transaction costs approach zero, there are inadequate funds to support critical infrastructure (stock exchanges, connectivity and broker dealers). As a result, markets begin to fail in the same way that other infrastructure, e.g., bridges, roads and tunnels, will fail when deprived of adequate revenue to fund maintenance and growth. ${ }^{18}$ At the SEC Advisory Committee meeting on Small and Emerging Companies on 8 June 2012, we shared our view that low commissions and low tick sizes erode markets from the bottom up - the small company ecosystem is the first to fail $^{19}$ unless counterbalancing measures are taken. ${ }^{20}$

\footnotetext{
${ }^{16}$ See "Glossary of Terms" for a definition.

17 Ibid.

${ }^{18}$ Weild, D. and E. Kim, "Killing the Stock Market that Laid the Golden Eggs", Chapter 12 in Arnuk and Saluzzi's (2012) Broken Markets, FT Press.

${ }^{19}$ See the webcast of the 8 June 2012 meeting of the SEC Advisory Committee on Small and Emerging Companies at http://www.sec.gov/info/smallbus/acsec.shtml.

${ }^{20}$ In many foreign markets, issuers counterbalance the effects of tiny tick sizes by splitting stock prices so that the minimum tick size becomes and increasing higher percentage of share price. This is the reason that in many countries we see concentrations of low-priced stocks. However, this option is impractical in the United States where the penny stock rules kick in under USD 5 per share and delisting occurs under USD 1 per share. In the United States, brokers are no longer allowed to solicit stocks under USD 5 per
} 
Regulators may find it expeditious to eliminate sales practice abuses by eliminating sales incentives. In addition, some academics rationalize that small companies fail at higher rates or perform more poorly ${ }^{21}$ than large companies and tend to be less proficient at disclosure, due to their lack of resources. So the elimination of small companies from public markets may make the life of regulators easier. It should be noted, however, that while small companies do fail at higher rates, it takes 2500 small company failures of companies averaging USD 100 million in market value to create the level of damage of one USD 250 billion market value failure.

\section{The drive to standardize markets}

While standardization is generally used to reduce costs, it is likely to add to systemic risk. Get it wrong, and the problems it creates may be propagated throughout the world. Favour one particular type or size of company, investor or intermediary, and all others may be put at peril. Properly functioning markets require a balancing of interests. As a result, we believe that innovation and choice in market structure (and even disclosure regimes when cost burdens become confiscatory) is actually something to be embraced. Some notable examples of the drive to standardize markets include common settlement through the Depository Trust \& Clearing Corporation (DTCC) in the U.S., the Markets in Financial Instruments Directive (MiFID) and MiFID II accords in Europe, and the potential to adopt and recognize IFRS accounting standards universally.

Left unchecked, well-intended initiatives may undermine capital formation, job growth and the very innovative companies that most governments seek to attract. In fact, this very problem has been recognized by the European Commission in their review of the impact of MiFID: "Small and medium-sized enterprises face greater difficulties and costs to raise capital from equity markets than larger issuers. These difficulties are related to the lack of visibility of SME [Small and Medium Enterprise] markets, the lack of liquidity for SME shares and the high cost of an initial public offering."22

Market structures that are optimized for large capitalization stock trading do not work to support SME markets. Thus, the economic growth and improvement in quality of life through scientific advancement that SMEs contribute may be put in jeopardy by many of these trends.

share and these stocks may no longer be held on margin. As a result, issuers are advised to maintain stock prices well in excess of USD 5 per share, essentially eliminating their ability to adequately increase tick sizes as a percent of share price.

${ }^{21}$ See materials from the 7 September 2012 Meeting of the SEC Advisory Committee on Small and Emerging Companies by Prof. Jay Ritter, Warrington College of Business Administration, University of Florida.

${ }^{22}$ European Commission (2011), Commission Staff Working Paper, Executive Summary of the Impact Assessment, 20 October, p. 2, http://ec.europa.eu/internal market/securities/docs/isd/mifid/SEC 20111227 en.pdf. 


\section{STOCK MARKET STRUCTURE IN THE UNITED STATES}

\subsection{History}

The U.S. capital markets have undergone a profound transformation in less than a generation - from the heights where it was the envy of the rest of the world's markets to the current depths where it is effectively closed to $80 \%$ of the companies that need it. Notably, Jiang Zemin, the President of the People's Republic of China from 1993 to 2003, once referred to The NASDAQ Stock Market as the "crown jewel of all that is great about America." ${ }^{3}$ President Jiang would hardly recognize the markets as they stand today.

In the early 1990s, we witnessed over 520 IPOs per year in the U.S., 80\% of which were small deals raising less than USD 50 million. Just twenty years later, that average has dwindled to fewer than 130 transactions, with just 113 in 2012, of which only 14 were small deals. ${ }^{24}$

Public company listings peaked in the U.S. in 1997, with 8823 exchange-listed companies. At the end of 2012, there were only 4916 - a massive decline of $44.3 \%{ }^{25}$ (see Exhibit 1). In fact, since the peak, the U.S. has suffered fifteen consecutive years of lost listings.

\subsection{Trends and observations}

\subsubsection{Economic incentives ("tick sizes" and commissions)}

\section{Quote versus electronic order}

As referenced previously, the pivotal events included the implementation of new order handling rules in 1997 and Regulation ATS in 1998. Virtually overnight, these rules effectively disintegrated the underlying economic support infrastructure that for decades had fueled the U.S. capital markets. The carnage at the small cap end of the market was most severe, as investment banks could no longer profitably provide the essential research, sales and trading commitment necessary for small companies to thrive as publicly traded entities.

Regulation ATS was hailed as an investor-friendly rule that would lower trading costs and level the playing field for the retail investor. Replacing the quote-driven market with "unfair" spreads with a new electronic order driven market was considered a necessary step in the evolution of markets. This shift, however, had profound consequences to the ecosystem of stock trading, particularly in small, less naturally liquid companies. While these consequences were surely unintended, they dramatically altered the market landscape.

\footnotetext{
${ }^{23}$ Cox, J. (2000), "U.S. Success Draws Envy", USA Today, 3 August, p. 1 B.

${ }^{24}$ Source: Weild \& Co., Grant Thornton LLP and Dealogic. Excludes closed-end funds, REITs, LPs, SPACs and other non-operating company financial vehicles. ${ }^{25}$ Ibid.
} 


\section{EXHIBIT 1}

\section{Percent Change in Number of Listed Companies for Selected Markets}

Indexed to 1997 (1997=0)

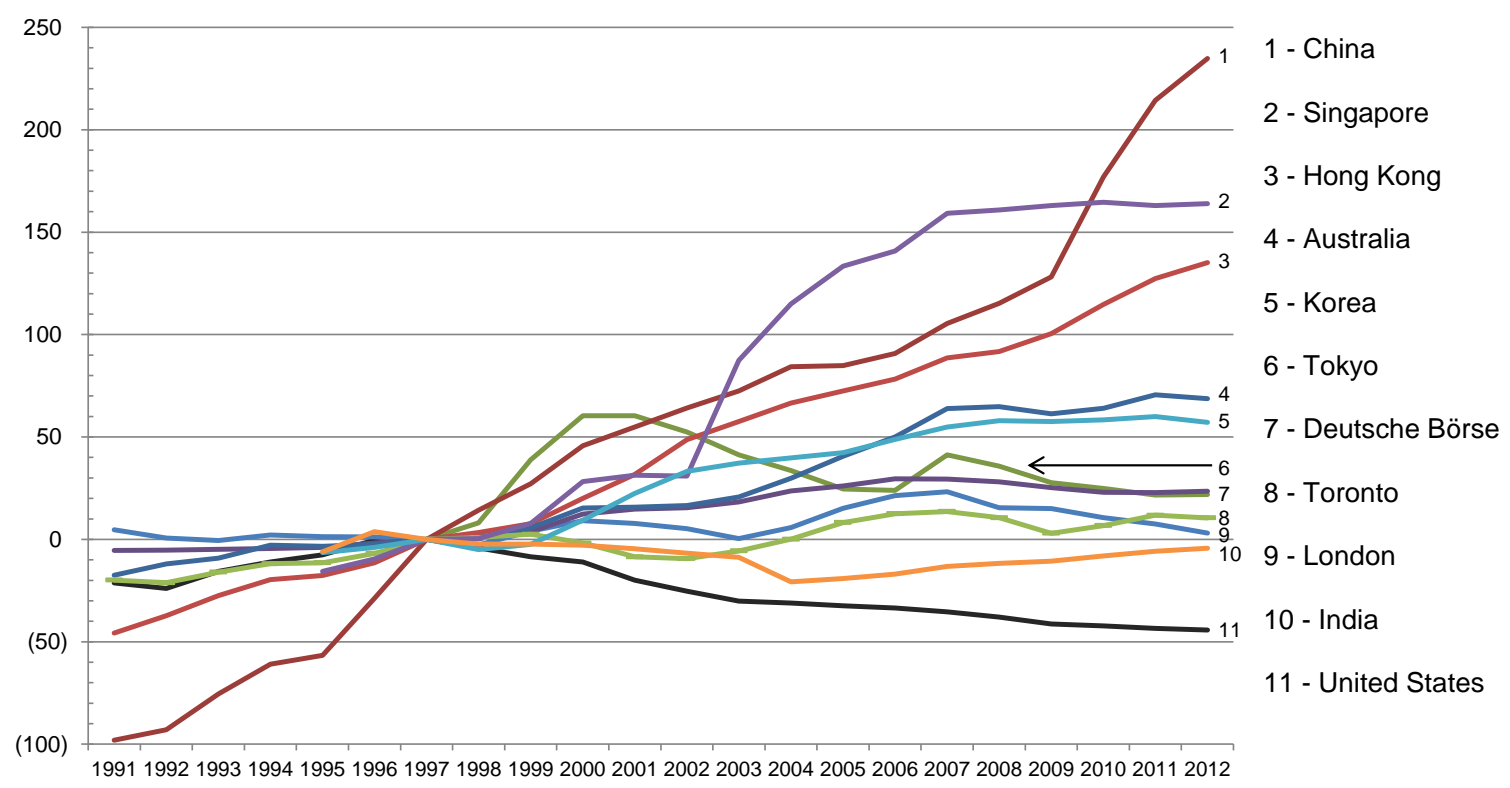

Sources: Weild \& Co., World Federation of Exchanges and the global stock exchanges

China includes Shanghai S.E. + Shenzhen S.E. India includes National S.E. + Bombay S.E.

Based on the number of listed companies at year-end, excluding funds, as of Dec. 2012.

"Tick sizes" and commissions

From 1991 to 1997, there were 2990 small IPOs, representing nearly $80 \%$ of all U.S. IPOs (see Exhibit 2). Although tick sizes during this time frame were largely in 12.5-cent increments, bankable spreads were largely in 25-cent increments. For example, in 1991, NASDAQ stocks priced at USD 10 or more traded with a tick size, or "floor," of 12.5 cents, while stocks priced below USD 10 traded with a tick size floor of 3.125 cents. Their bankable spreads, however, were still frequently 25 cents.

In the wake of Regulation ATS, however, bankable spreads and tick sizes quickly converged, as the rapid proliferation of electronically posted orders from electronic communication networks, crossing networks and other alternative trading systems inexorably drove down tick sizes and bankable spreads to only one cent per share-a level that was grossly insufficient to sustain small company capital formation. The aftermarket support model that had worked so well for so long had collapsed, and with it, inevitably, so did small company IPOs. 


\section{EXHIBIT 2}

The "one-two punch" of small tick sizes and the shift to electronic order book markets precipitated a secular decline in the U.S. stock markets

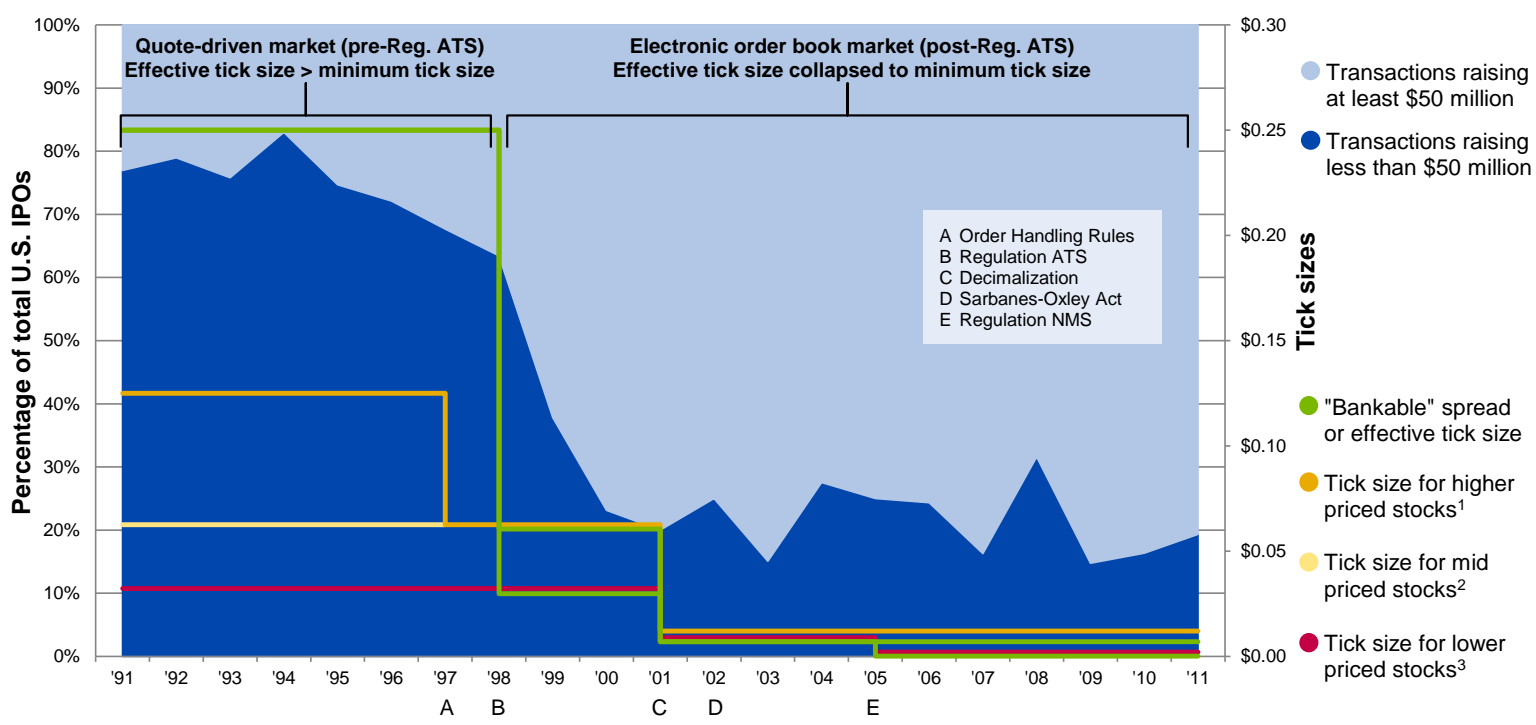

Sources: Grant Thornton LLP, Weild \& Co. and Dealogic

Data includes corporate IPOs as of Dec. 31, 2011, excluding funds, REITs, SPACs and LPs.

11992: $\$ 0.125$ for NASDAQ stocks $\geq \$ 10$, AMEX stocks $\geq \$ 5$ ( $\geq \$ 10$ in 1995) and NYSE stocks $>\$ 1 ; 1997: \$ 0.0625$ for NASDAQ stocks $\geq \$ 10$,

AMEX stocks $\geq \$ 0.25$ and NYSE stocks $\geq \$ 0.50$

21992: $\$ 0.0625$ for AMEX stocks $\geq \$ 0.25$ and $<\$ 5$ and NYSE stocks $>\$ 0.50$ and $<\$ 1$.

31992: $\$ 0.03125$ for NASDAQ stocks $<\$ 10$, AMEX stocks $<\$ 0.25$ and NYSE stocks $<\$ 0.50$.

\subsubsection{Why tick sizes are critical in electronic markets}

Market makers must be able to manage their risk of loss and generate a return on capital. When market structure destroys the profit on market maker capital (as has occurred with electronic order book markets and one cent tick sizes in the United States), the managements of broker-dealers react logically by cutting the capital allocated to market makers and pursuing an agency-only (no capital), electronic execution strategy.

Capital is not necessary to support liquidity in large capitalization stocks. As discussed elsewhere in this study, these markets benefit from the network effect and many simultaneous buyers and sellers. However, capital is necessary, and thus the ability to earn a profit on capital deployed, to support smaller company stocks that trade episodically (not continuously) and require constant support through marketing and capital commitment.

In the pre-Regulation ATS (pre-electronic trading) world, a market maker enjoyed a large "quoted" market with 25 cent quote increments. For example, in the US, a stock might be quoted USD 10.00 bid by USD 10.25 ask - i.e., the market was offering to buy stock at USD 10.00 per share and to sell it at USD 10.25. These were not firm bids or offers, and an investor generally needed to call the market maker to determine what size (how many shares) that market maker was willing to buy or sell and at what price. Thus, the quoted markets were really an advertisement or invitation to negotiate and not a firm order. The convention of a large ( 25 cent) spread (the difference between the bid and the ask) made it very expensive for a market maker to attempt to sell short into the bid of another market maker, because it would cost the seller 25 cents per share. So, market makers might buy 100000 shares of a stock from an institutional investor at USD 10.00 and make sales to other investors at prices up to the USD 10.25 ask side of the market. As a result, between the market maker buying the block of 100000 shares of stock, and the stock brokers who were marketing it, there stood to be as much as 25 cents or $2.5 \%$ returned (before payouts 
to salesmen and traders) on capital committed. Short sellers were dissuaded from selling stock at USD 10.25 when they would have to see the stock price decline by 25 cents per share to USD 9.75 bid by USD 10.00 ask before they could be assured of a profit.

In today's one cent tick size electronic markets, all posted prices are live orders. While we can and do still find stocks that are quoted at the same price, as in the example above, namely USD 10.00 bid by USD 10.25 ask, if that same market maker were to buy that block of 100000 shares at USD 10.00 per share, a short seller could now offer stock at USD 10.01 or even USD 10.00. In the case of offering stock at USD 10.01, the spread has now collapsed to 1 cent per share. The market maker and his salesforce have now seen their profit motive collapse from $2.5 \%$ to $0.1 \%$ - hardly enough money to cover costs. And, if the short seller suspects that the market maker has a 100000 share position that cannot be easily placed with investors, the short seller will now electronically route sales to the USD 10.00 bid until the buyer collapses and price goes below USD 10.00. Short sellers now only need to push the bid down by merely one cent to USD 9.99 before they can cover their short and make money.

As a result, market making that utilizes capital, and is essential to sustain quality small company markets, has disappeared from electronic order book markets. Firms now pursue strategies as proprietary traders (trading as investors for their own account) or as agency traders (simply processing orders). Market making, as it once was known, is largely extinct and small companies are deprived of the capital required to support liquidity in their shares.

The inescapable lesson is that while one cent tick sizes may work for large capitalization stocks, much larger tick sizes (minimal price variations) are essential to sustain smaller capitalization markets unless that market has a convention where it does not penalize issuers who split their stock prices to lower price levels-say USD 0.10 to USD 0.50 per share-where a one cent tick size will suddenly, in percentage terms, represent a significant percent incentive of $10 \%$ (USD 0.01 /USD 0.10 ) or $2 \%$ (USD 0.01 /USD 0.50), respectively.

The reader should note that it is not stock exchange profitability, or even brokerage firm profitability, that is the problem here. Stock exchanges earn significant profits increasingly from the sale of data or investor relations services. Brokerage firms earn money by proliferating derivatives and other packaged product (e.g., ETFs and closed-end funds). What has been taken away are the incentives for brokerage firms to invest in the essential services required to support small company liquidity and access to capital: return on capital to support market making, adequate commissions so that stock brokers can earn a living selling individual stocks, and a return model that will cover the cost of more equity research to support both market makers and stock brokers.

The ecosystem to support small public companies, capital formation and economic growth has simply been gutted by the one cent tick size, electronic-order-book model where practices prevent companies from adequately splitting their share prices to low enough increments to create adequate economic incentives to attract real market making.

\subsubsection{Disincentives}

While Regulation ATS was the catalyst for the destruction of the small company capital formation ecosystem in the U.S., there were several regulatory rulings that aggravated a worsening condition. 
Regulation Fair Disclosure (FD) was adopted by the SEC in 2000, mandating that companies must disclose all material information to all investors simultaneously. On its face, this was a simple ruling aimed at levelling the playing field for retail investors. The unintended consequences, however, were far reaching and severely damaging for small companies and were exacerbated by the environment of diminishing tick sizes and bankable spreads.

In perfect hindsight, Regulation FD created more problems than it solved. Perversely, this simultaneous disclosure requirement served to devalue research. Institutions stopped paying a premium for it, and the need for research on the retail side of the business, with stock brokers unable to earn a proper commission, was diminished. The best and brightest of the sell-side analysts left Wall Street in search of more lucrative opportunities at hedge funds. The "dumbing-down" of stock research was in full swing and companies were left orphaned, either without coverage or with increasingly ineffective coverage.

\section{Sarbanes-Oxley}

The Sarbanes-Oxley Act of 2002 is commonly cited as a major cause of the decline of the IPO market in the U.S. While the Act certainly impacted the cost and time for companies to become public, it clearly was not the major factor, given that it did not take effect until fully four years after the passage of Regulation ATS.

We fully support the recent revision to Sarbanes-Oxley, mandated by the JOBS Act for companies with under USD 1 billion in revenues, as compliance under Sarbanes-Oxley appears to have inhibited smaller companies from attempting to go public. We would not, however, expect this rollback, in isolation, to have a dramatic impact on the IPO market, in general, and in small company filings, in particular.

\section{The Global Research Analyst Settlement}

The Global Research Analyst Settlement of 2003 (the "Global Settlement") may have been the final death knell for small company IPOs. Again, perversely, equity research was rendered less independent of investment banking than it was prior to the Global Settlement. ${ }^{26}$

The economics to support equity research-trading and commissions-have been so eroded that the only significant economics left come from investment banking. In fact, the average number of investment banking bookrunners and co-managers has increased steadily across all transaction sizes since the Global Settlement. ${ }^{27}$ This is because the

\footnotetext{
${ }^{26}$ Global Research Analyst Settlement: The SEC, the NYSE, the NASD (now FINRA), the New York Attorney General's Office and the North American Securities Administrators Association established a joint agreement reached with ten of the largest securities firms to address conflicts between research and investment banking. As part of the settlement, these firms agreed to insulate their banking and research departments from each other, to prohibit analysts from being compensated on a particular investment banking transaction, to prohibit investment banking from having any input into research compensation or coverage decisions, and to prohibit research analysts from accompanying investment bankers on pitches and road shows to solicit business or market new issues, including IPOs. Firms were penalized with USD 1.4 billion in collective penalties.

${ }^{27}$ Weild, D. and E. Kim (2008), "Why are IPOs in the ICU?”, Grant Thornton LLP, www.gt.com/staticfiles/GTCom/files/GT\%20Thinking/IPO\%20white\%20paper/Why\%20are\%20IPOs\%20i n\%20the\%20ICU 11 19.pdf.
} 
aftermarket commission and trading economics before Regulation ATS were generally adequate to attract analyst coverage independent of the transaction.

Today, all analyst coverage typically comes from the investment banking management team, and experience shows that some of these banks will fail to provide coverage. The bottom line is that, despite the best intentions of the Global Settlement, research coverage is far more difficult for issuers to secure and is likely to be limited to the investment banking management team.

\subsubsection{Symmetrical versus asymmetrical markets}

The erosion of aftermarket economics is most keenly felt at the small cap, less liquid end of the market, where active support from market makers and liquidity providers is crucial. These markets are referred to as "asymmetrical"-typically one-sided with a buyer or seller with no other side. Asymmetrical order books (and the corresponding asymmetry in available information) lead to disorderly markets and sharp swings in price with no meaningful volume - not a happy outcome for any market constituency.

Larger, more liquid stocks benefit from symmetrical markets and information. These stocks trade with minimal assistance or intervention, because of tremendous interest on both sides. Strength at the upper tier of the market is reflected in indices such as the Dow Jones Industrial Average and the S\&P 500, frequently masking the deterioration of the small cap markets that lie beneath.

\subsubsection{Quality of the price discovery process in the new market structure}

The birth of dark pools

What we think of today as "dark pools" were born from electronic crossing networks ("ECNs") for large blocks of stock. Instinet, which was founded in the late 1960s, was the first such ECN. These ECNs were a natural evolution in the market that was spurred by the dramatic growth in mutual funds.

As funds grew and their need for executing larger and larger trades grew correspondingly, the demands began to overwhelm the capacity of the NYSE and NASDAQ to provide orderly markets. Exposing the size and side of these large orders to floor brokers, specialists and market makers resulted in adverse price movement before an execution was able to be completed. It was clear that a mechanism was needed to enable these institutions to interact in block size with minimal information leakage. ${ }^{28}$

The "old normal" versus the "new normal"

While the early dark pools filled an important market need, Regulation ATS opened the floodgates for the proliferation of ECNs. Wall Street quickly saw an opportunity to launch its own dark pools. Today, all major brokerage firms operate their own such pools, while high frequency trading (HFT) firms have also opened dark pools.

While the early ECNs served to match institutional order flow, today's dark pools largely serve a vastly different purpose. Rather than interacting with other investor orders, orders routed through these pools are primarily interacting with the brokerage firms' internal orders

${ }^{28}$ Arnuk, S. and J. Saluzzi (2012), Broken Markets, FT Press. 
or HFT firms' proprietary business. Investor orders in these dark pools are routinely disadvantaged and gamed, resulting in inferior price execution.

Specifically, internalization by HFT firms has created a nightmare scenario for true investors. HFT firms can step in front of displayed limit order by mere fractions of a penny, depriving investors of fair executions. For example, you may have an order to sell 5000 shares of $A B C$ at USD 20.00. A buyer wants to purchase your shares, but his order gets routed through the brokerage firm's internal book and then often through an HFT-owned dark pool. The buyer gets filled at USD 19.9999 by an HFT firm instead of by you at USD 20.00 .

Investors cannot use sub-penny prices to enter orders, yet brokerage firms and HFT firms can-and do it constantly. Investors lose trading opportunities, but, more importantly, the integrity of public markets and fair pricing has been destroyed. The incentive for investors to display their orders in a theoretically level playing field does not actually exist. Rather, those orders are used against the investors themselves. ${ }^{29}$

\subsubsection{Primary (equities) versus secondary (derivatives) trends and effects}

The market structure in the U.S. has evolved-if one can call it evolution-into a market that discourages long-term, fundamental investment and encourages short-term, hypertrading with no regard to the nature of a company's business or its investment merits. In other words, our markets no longer serve the purpose for which they were created, i.e., to facilitate capital formation.

\section{Exchange traded funds}

While IPOs of corporations continue to languish in the U.S., there has been an explosion in the growth of ETFs. While ETFs provide a convenient vehicle to participate in a targeted sector, they have increasingly become critical components of HFT strategies. As volume has dried up in small cap, less liquid stocks, volume has flourished in these derivatives.

The trend has become so dire that even John "Jack" Bogle, the founder and retired CEO of The Vanguard Group and the "father of index funds" as a strategy, has expressed his concern about the impact of ETFs on volatility and market risk. In a Wall Street Journal interview, he stated that indexing "has been bastardized" and that ETFs often "are just great big gambling, speculative instruments that have definitely destabilized the market." 30

\section{The Flash Crash}

In exhaustive examinations of the events of 6 May 2010, the SEC concluded ultimately that the Flash Crash was caused by the structure of the markets themselves. The initial selling led to more selling in a brutal ripple effect that fed on itself and cascaded. ${ }^{31}$ This feedback and cascade loop was not a mistake or a glitch in the market. R.T. Leuchtkafer, who is a knowledgeable writer, prolific editorialist and commenter to the SEC, said that this

\footnotetext{
29 Ibid.

${ }^{30}$ Zweig, J. (2011), "Why a Legendary Market Skeptic is Upbeat About Stocks", Wall Street Journal, 10 September.

31 "Meeting of the Joint CFTC-SEC Advisory Committee on Emerging Regulatory Issues," 24 May 2010.
} 
deathly feedback and cascade were "a feature of the newly deregulated stock market, of privileged but substantially lawless HFT market makers." ${ }^{32}$

\subsubsection{Impact on strategies}

Management teams of small corporate issuers today are faced with a Hobson's choice of unappetizing options. Go public and hope that investors will find us? Stay private and hope that an acquirer will find us? Hope is a poor substitute for a strategy, but this is the unenviable position of many small company management teams and boards.

Small issuers can no longer rely on the capital markets to function as they once did, particularly if they have a small public float or if they have an investment story that is complex or multi-layered. Investment banks simply cannot make any money in the aftermarket by supporting small cap, less liquid companies with research, trading and sales support, and must focus on the largest, most liquid stocks. Consequently, they must focus on those institutional accounts that are most active in those large caps. In conversations with our colleagues at the leading banks, we have gleaned that their commission and prime brokerage revenue is dominated by the top 60 or 70 accounts, leaving thousands of accounts completely off their radar.

Retail brokers, who once were the prime purveyors of investment ideas, no longer can afford to spend time finding individual stocks to recommend. Rather, they are asset gatherers who are more focused on accumulating wrap fees, instead of finding long-term investment ideas for their clients.

For many small companies and their venture capital investors, the merger and acquisition route is essentially the only option. But acquisition valuations may not reach their full potential without a viable IPO market as a competing alternative. A vibrant and efficient IPO market would absolutely benefit companies seeking to be acquired. As it is, potential acquirers know they hold all the leverage at the negotiating table.

Venture capital firms can no longer rely on a relatively quick IPO to access larger amounts of cost-effective capital. In the 1980s and 1990s, the time from first investment to IPO was an average of four years. Today, it is eight years. ${ }^{33}$ This added duration creates additional stress for the venture capitalist by handcuffing money and making it impractical to raise the next fund.

The evidence suggests that financial sponsors have not been adversely affected by the current market structure. Private equity transactions tend to be more focused on mid-cap and large-cap companies. We have seen a number of large private equity-backed deals come to market, particularly in secondary transactions. In fact, as of March 2013, global financial sponsor activity has been at the highest year-to-date level ever, both in number of transactions and in dollar volume. ${ }^{34}$

It is instructive to examine how the changes in market structure have affected institutional investor behavior. With liquidity drying up at the microcap end of the market, funds must seek alternate sources of growth. Before we examined the changes in microcap investment, we had obviously expected a decrease, but we were still surprised at the

\footnotetext{
${ }^{32}$ Leuchkafer, R.T., "The Flash Crash", Chapter 10 in Arnuk and Saluzzi's (2012) Broken Markets, FT Press.

${ }^{33}$ Source: NVCA Yearbook 2013, page 13, Figure 9 at www.nvca.org.

${ }^{34}$ Source: Dealogic.
} 
magnitude (see Exhibits 3 and 4). Fundamentally-oriented institutions, which historically sought growth opportunities in microcap stocks, have largely abandoned the segment in search of greater liquidity opportunities up the market cap scale.

Actively trading funds have clearly benefitted the most from the current penny tick size environment, which provides a near frictionless market in which to trade. Still, these funds must be feeling competitive pressure from their fundamentally-oriented peers, who are increasing their investments in large cap stocks.

The largest hedge funds have been shown to be lagging in performance when compared to their smaller peers. A study published in February 2013 of long/short hedge fund performance by Beachhead Capital Management demonstrated that small hedge funds (under USD 500 million in AUM) outperformed large funds by 254 basis points and 220 basis points per year, over five years and ten years, respectively. This result may be due to the fact that smaller funds "have a better opportunity set" and "off the run and less efficiently priced stocks" can have a meaningful impact on returns. ${ }^{35}$

Pension funds, like their other institutional peers, have been constantly seeking opportunities for greater returns in the absence of a liquid small cap market. One manifestation of this is that pension funds' allocation to hedge funds continues to increase. Investment in hedge funds and hedge funds-of-funds by the 200 largest U.S. retirement funds jumped $20.3 \%$ to USD 134.7 billion in the year ended 30 September $2012 .{ }^{36}$

\footnotetext{
${ }^{35}$ Beachhead Capital Management, "Performance of Emerging Equity Long/Short Hedge Fund Managers: 20032012", February 2013.

${ }^{36}$ Williamson, Christine, "Top pension funds put $20.3 \%$ more into hedge fund strategies," Pensions \& Investments, 4 February 2013.
} 


\section{EXHIBIT 3}

\section{AUM $^{(1)}$ in U.S. Micro Cap ${ }^{(2)}$ Market Declined Dramatically from 1999 to 2010}

Distribution $^{(3)}$ of Fundamentally-Oriented U.S. Institutions

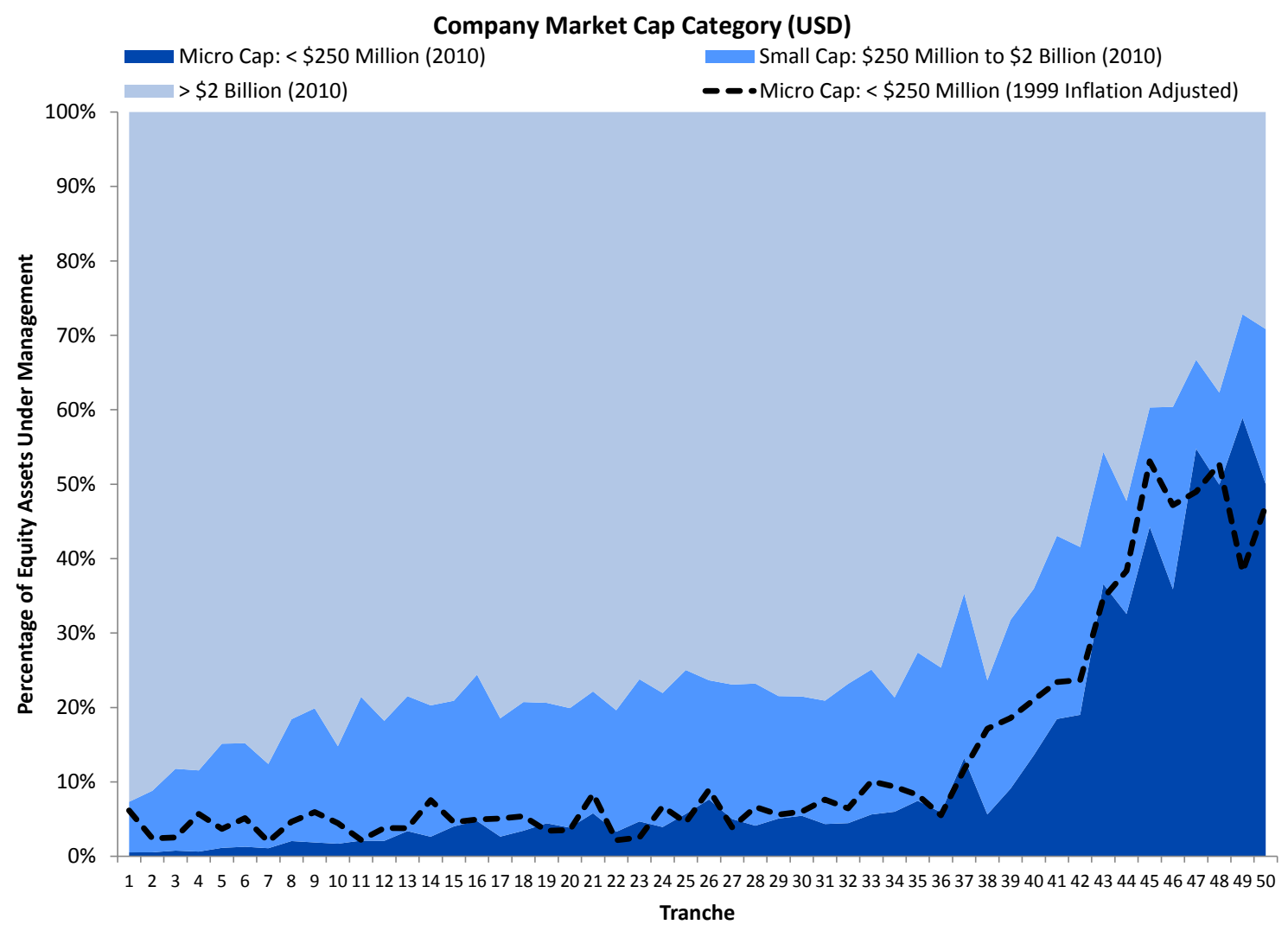

${ }^{(1)} \mathrm{AUM}=$ Assets Under Management

${ }^{(2)}$ Note: "Micro Cap" for these purposes is defined as sub $\$ 250$ million USD, not $\$ 100$ million to $\$ 500$ million USD as defined in other section of the paper. This is due to a limitation in the FactSet database.

${ }^{(3)}$ We divided the population of fundamental institutional equity asset managers into fifty slices. The largest asset managers are in slice 1 (e.g., Fidelity, Wellington and BlackRock) and the smallest are in the $50^{\text {th }}$ slice.

Number of Institutions (1999) $=3,283$

Number of Institutions (2010) $=3,543$

Total equity assets under management (1999 inflation adjusted) $=\$ 4.4$ trillion (USD)

Total equity assets under management $(2010)=\$ 10.8$ trillion (USD)

Sources: Weild \& Co., Grant Thornton LLP, FactSet and the U.S. Department of Labor 


\section{EXHIBIT 4}

\section{Fundamentally-Oriented U.S. Institutional Equity Investors}

Change in Percentage of Equity Assets Invested by Market Cap from 1999 vs. 2010 (Inflation Adjusted)

Micro Cap: < \$250 Million

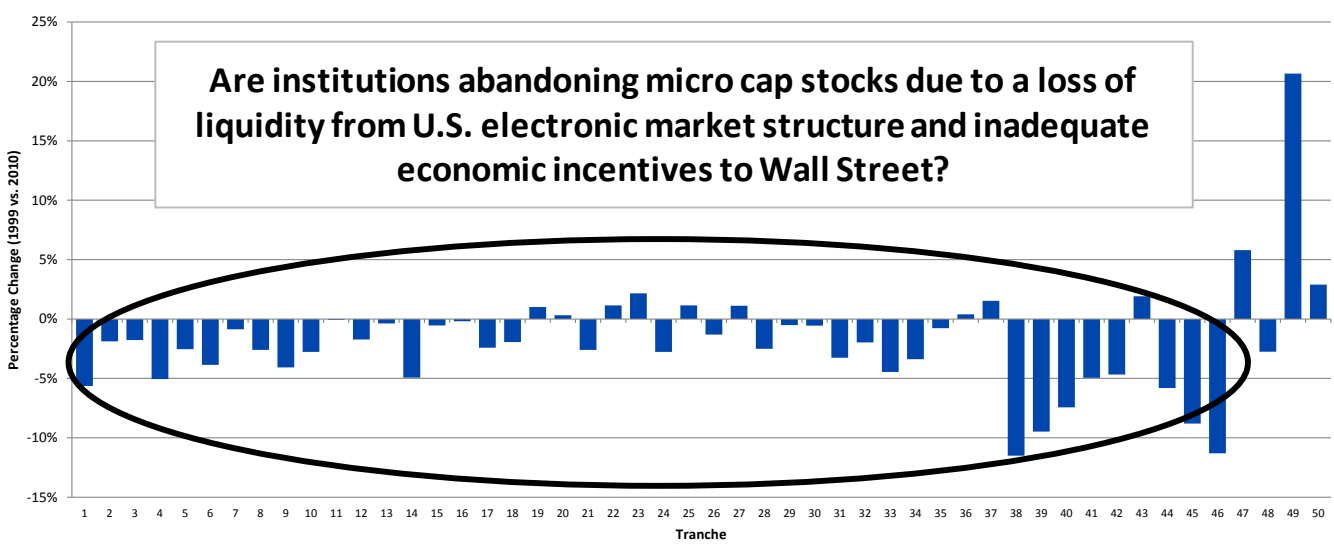

Small Cap: \$250 Million to \$2 Billion

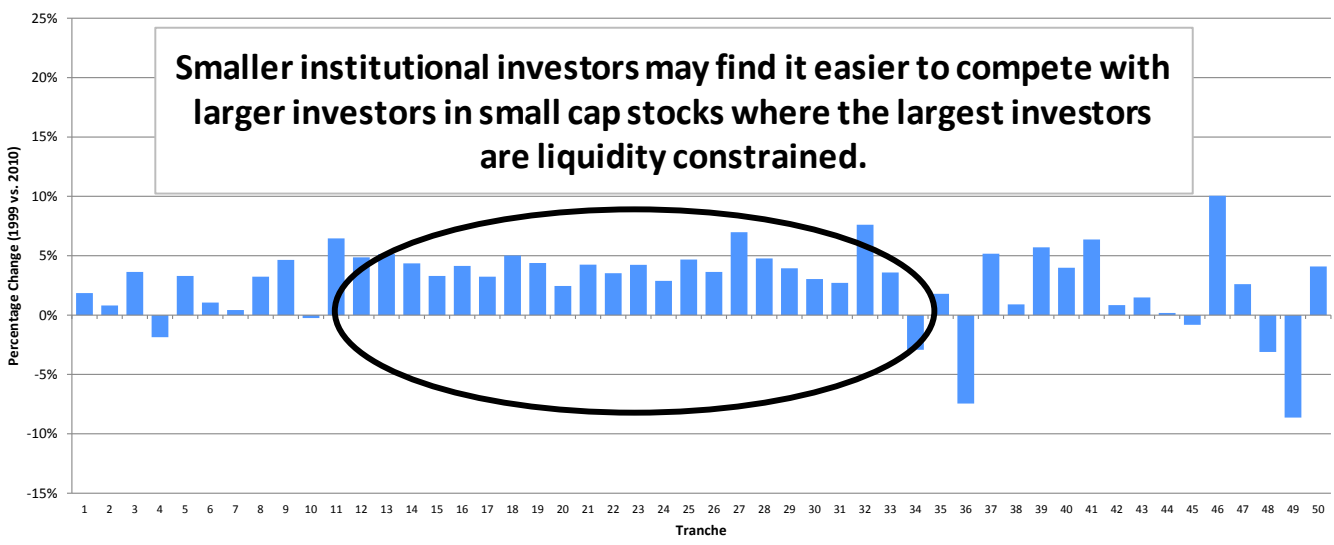

Market Cap > \$2 Billion

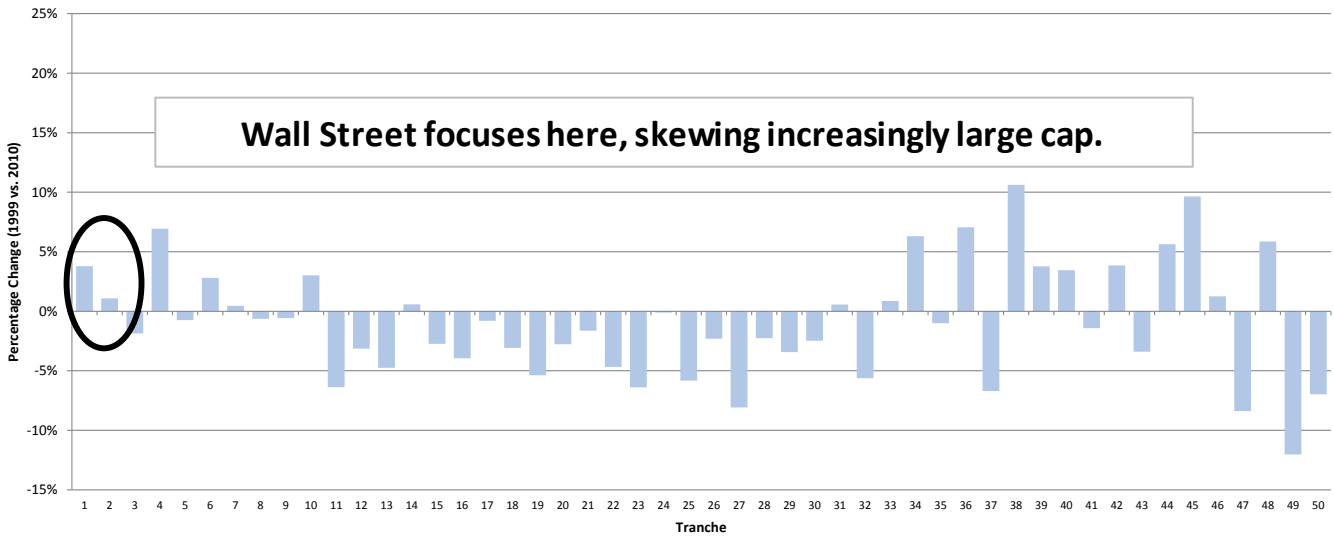

We divided the population of fundamental institutional equity asset managers into fifty slices. The largest asset managers are in slice 1 (e.g., Fidelity, Wellington and BlackRock) and the smallest are in the 50th slice. Number of Institutions (1999) = 3,283

Number of Institutions (2010) $=3,543$

Sources: Weild \& Co., Grant Thornton LLP, FactSet and the U.S. Department of Labor 
IPO MARKETS (U.S. AND ABROAD) AND LISTINGS

\subsection{History}

Prior to 1998, the U.S. stock market structure provided a foundation for many small IPOs with less than USD 50 million in proceeds to successfully access the U.S. capital markets. In examining the IPO market that preceded the Dot-Com Bubble of 1996, the PreBubble period produced about the same number of IPOs as the Dot-Com Bubble period, yet the Pre-Bubble period had over four times more IPOs than the Post-Bubble period beginning in 2001. Prior to the Dot-Com Bubble, the United States produced an average of 520 IPOs per year. The average number of IPOs has now fallen by $76 \%$ to only 126 IPOs per year since 2001.

For companies that still choose to go public in the United States, we find that there has been a secular decline in their IPO success rates (see Exhibit 5). Companies going public today are failing at increasingly higher rates, as more deals are being withdrawn, priced below their initial filing range and trading below their offer price. This decline in IPO success rates has been exacerbated by the steady degradation in equity sales coverage of institutional and retail investors that is, in turn, a reaction to the erosion in bankable spreads and commissions.

\section{EXHIBIT 5}

IPO success rates are in secular decline Success rate of all IPOs

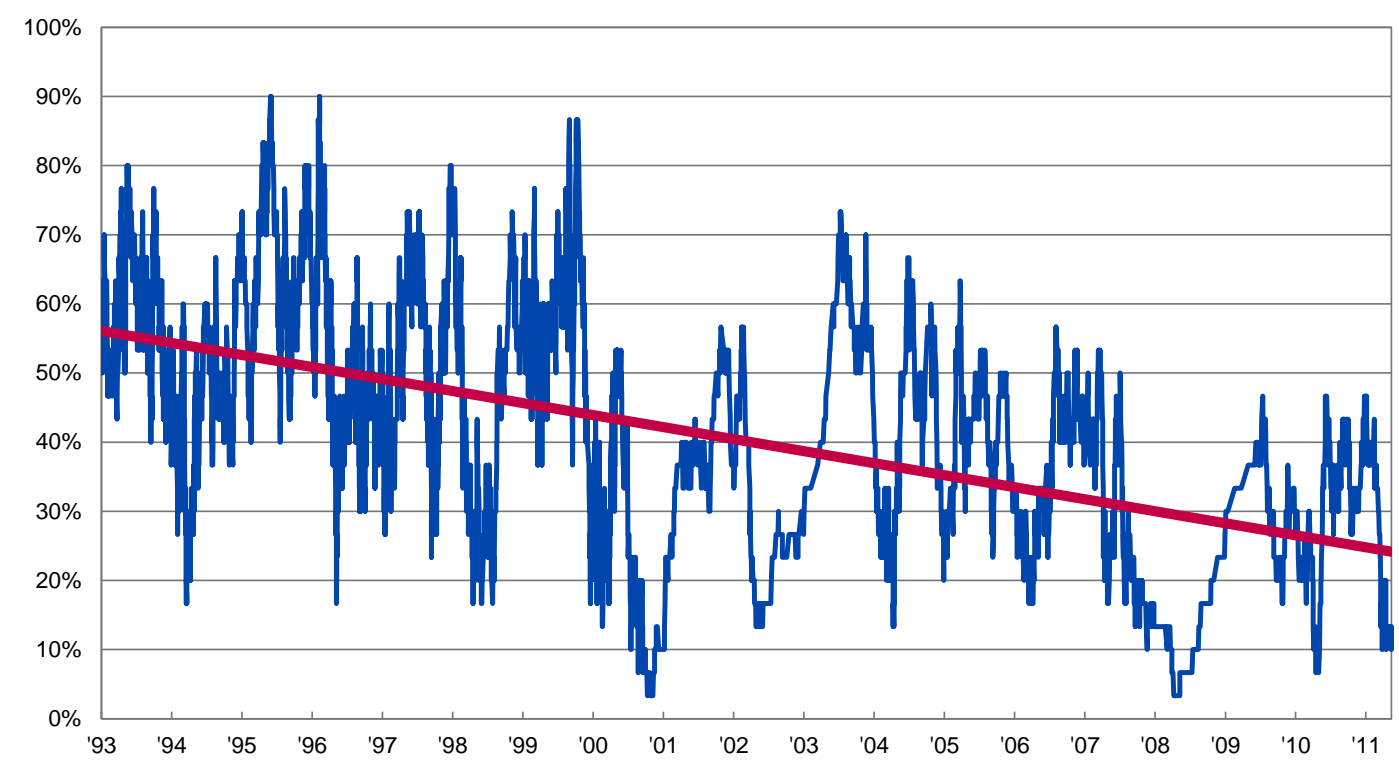

Source: Weild \& Co.

Includes only corporate issuers, excluding funds, MLPs, SPACs and REITs.

Based on the average success rate of the last 30 filed deals, up to one year ago. A successful deal is defined as 1) priced within one year of filing, 2) priced at or above the low end of the filing range and 3) trading at or above issue price one month after pricing. 
To determine which countries have been gaining or losing ground, in terms of the number of small and large domestic IPOs they have produced, we examined the relative rankings of 26 jurisdictions (Australia; Brazil; Canada; Chile; China; France; Germany; Hong Kong, China; India; Indonesia; Israel; Italy; Japan; Malaysia; Mexico; Norway; Poland; Saudi Arabia; Singapore; South Korea; Spain; Chinese Taipei; Thailand; Turkey; the United Kingdom and the United States) for three different time periods (1996 to 2000, 2001 to 2005, and 2008 to 2012). These jurisdictions were chosen based on their top ranking in the IPO markets from 2008 to 2012 .

We found that countries with higher than average tick sizes as a percentage of share price in smaller stocks, such as Australia and Canada, have significantly increased their relative ranking in the number of small IPOs that are under USD 50 million in proceeds (see Exhibit 6). Australia and Canada now rank \#3 and \#1, respectively, for the period from 2008 to 2012. South Korea, which has significant governmental intervention and tax incentives, has also increased its standing. The United States, which was once in first place for the number of deals under USD 50 million from 1996 to 2000, and has low tick sizes as a percentage of share price, has fallen to twelfth place for small IPOs - a decline of eleven positions that is among the largest moves, up or down, for the 26 jurisdictions.

The comparison of country rankings in small versus large IPO production is a useful diagnostic that can help point to changes in market structure or policy that may require further investigation, since economic factors generally lead to parallel shifts in ranking for a given jurisdiction. For example, Italy's decline and convergence is a pattern consistent with the country's economic struggles and uncertainty. Similarly, discriminatory policies that favour or disfavour small IPOs over large IPOs, or vice versa, will result in non-parallel shifts that require further investigation to determine their cause. 


\section{EXHIBIT 6}

\section{Country Ranks}

Ranking Based on Number of IPOs (Domestic Listings)
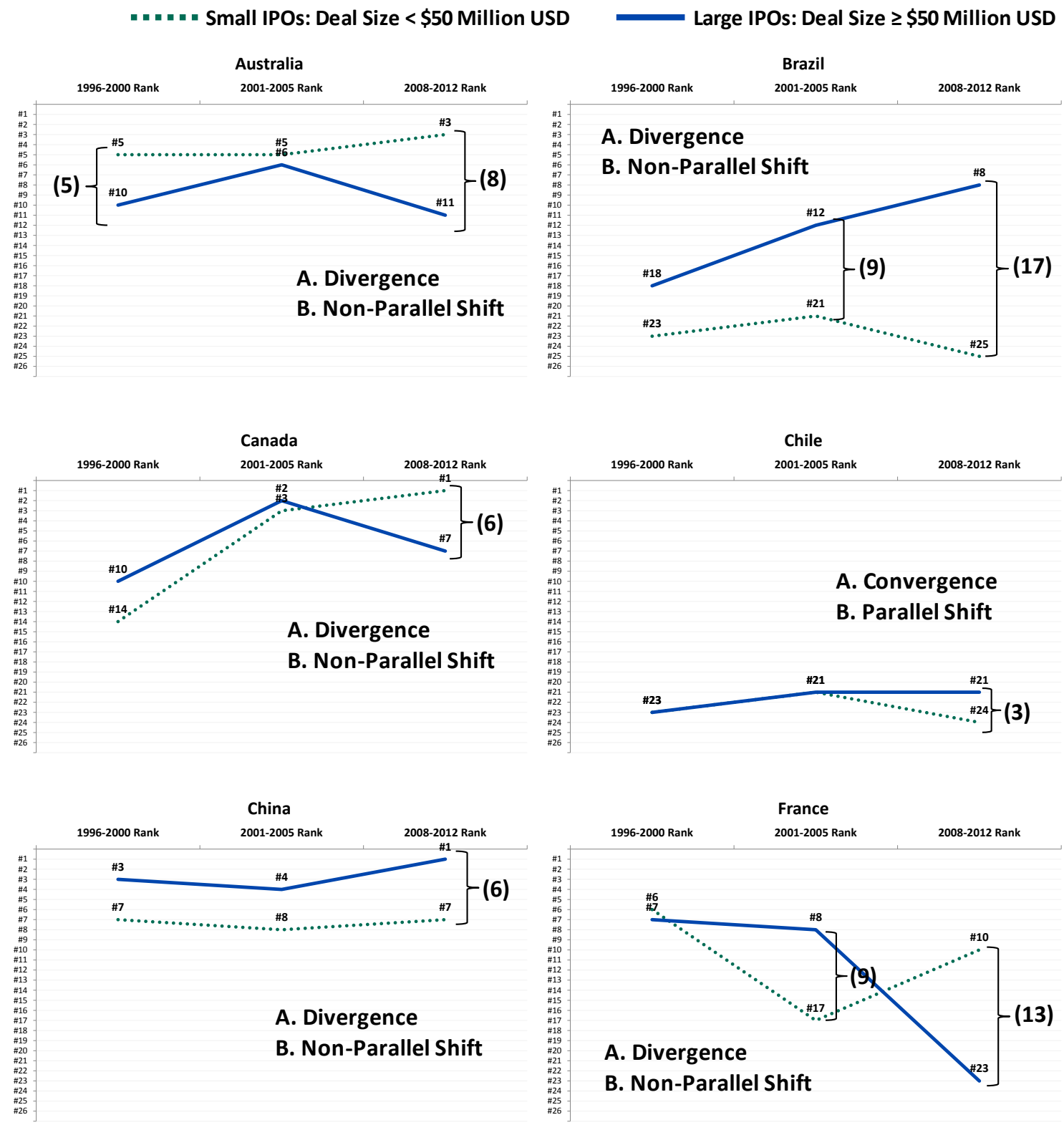

Key:

A. Convergence vs. Divergence: When policies and/or market structure equally favor (or disfavor) small and large IPOs, relative country rank will be similar (i.e., "convergence") for both the small and large IPO segments.

B. Parallel vs. Non-Parallel Shifts: Parallel shifts are generally driven by market and economic factors, while non-parallel shifts are more likely due to policy (including market structure) shifts.

Includes domestic corporate IPOs as of Dec. 31, 2012, excluding funds, LPs, SPACs, REITs and other trusts. 


\section{Country Ranks}

Ranking Based on Number of IPOs (Domestic Listings)
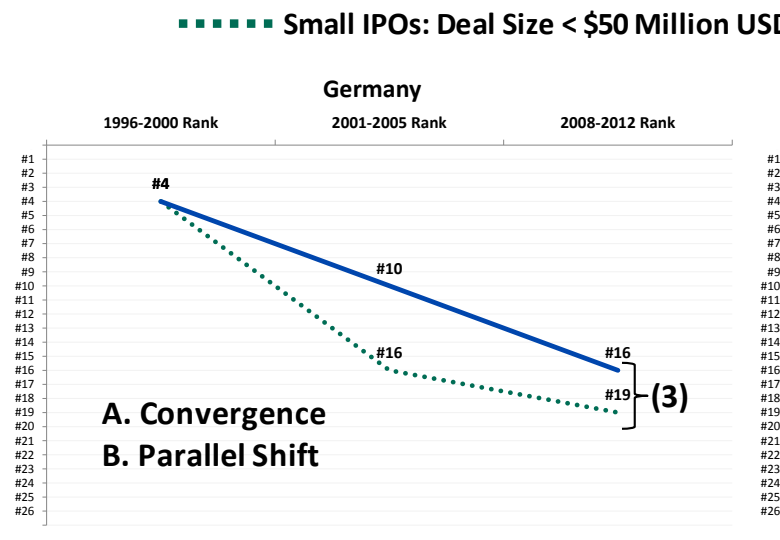

Large IPOs: Deal Size $\geq \$ 50$ Million USD

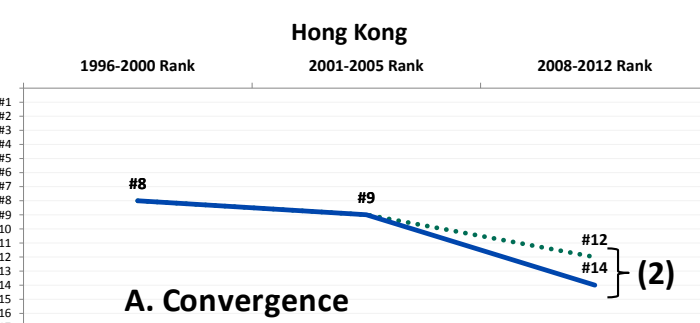

B. Parallel Shift

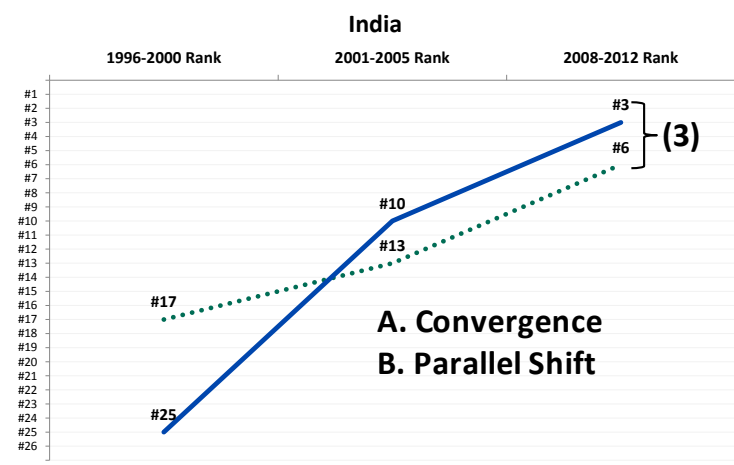

\begin{tabular}{l} 
Indonesia \\
2001-2005 Rank $\quad$ 1996-2000 Rank 2008-2012 Rank \\
\hline 1
\end{tabular}
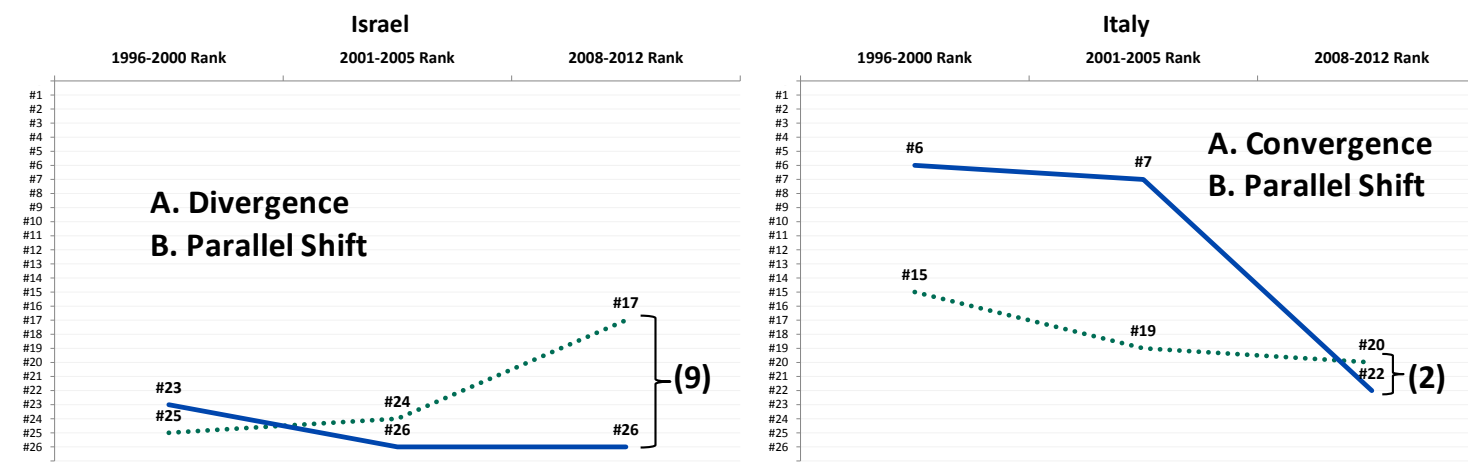

Key:

A. Convergence vs. Divergence: When policies and/or market structure equally favor (or disfavor) small and large IPOs, relative country rank will be similar (i.e., "convergence") for both the small and large IPO segments.

B. Parallel vs. Non-Parallel Shifts: Parallel shifts are generally driven by market and economic factors, while non-parallel shifts are more likely due to policy (including market structure) shifts.

Includes domestic corporate IPOs as of Dec. 31, 2012, excluding funds, LPs, SPACs, REITs and other trusts. 


\section{Country Ranks}

Ranking Based on Number of IPOs (Domestic Listings)
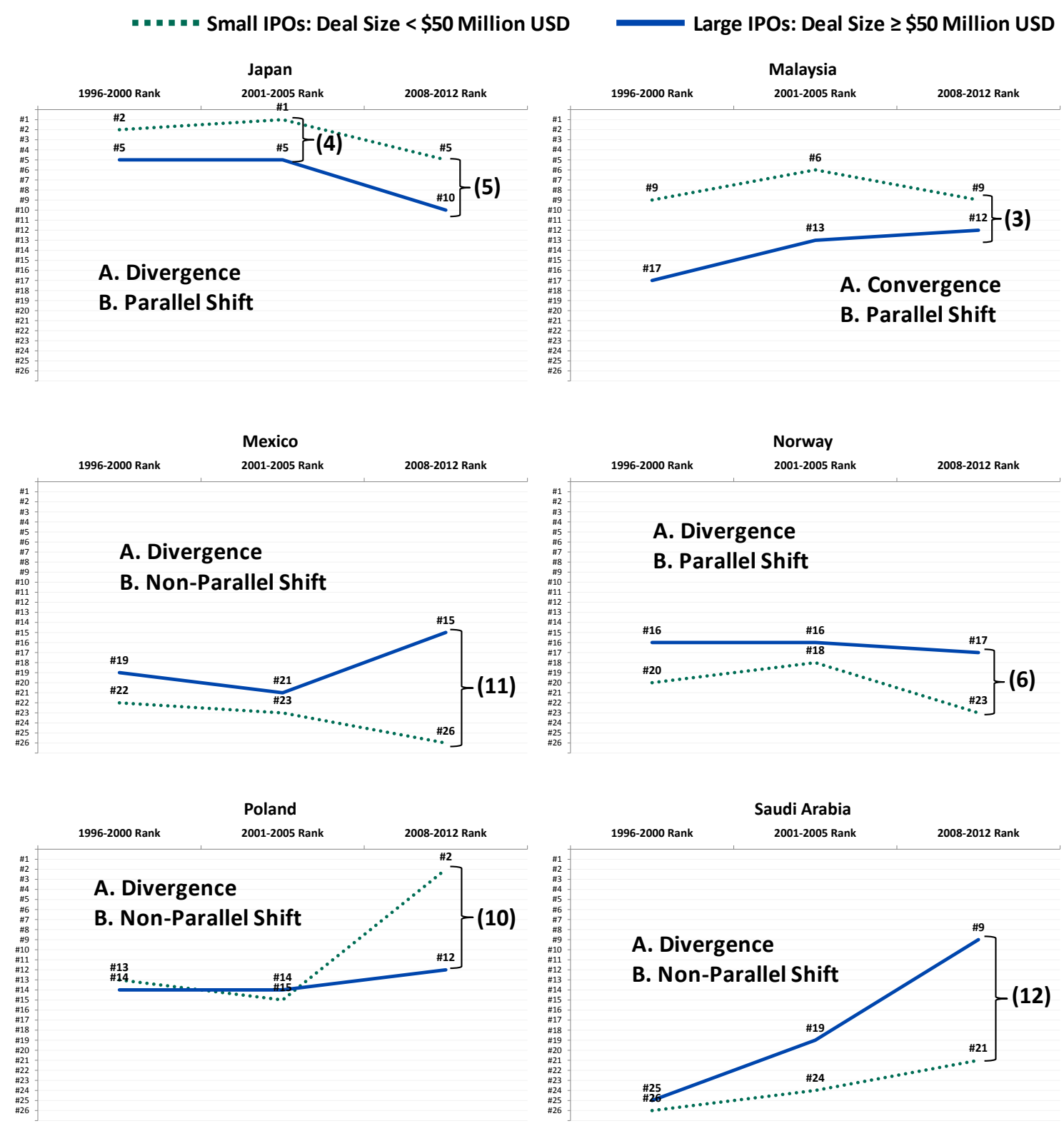

Key:

A. Convergence vs. Divergence: When policies and/or market structure equally favor (or disfavor) small and large IPOs, relative country rank will be similar (i.e., "convergence") for both the small and large IPO segments.

B. Parallel vs. Non-Parallel Shifts: Parallel shifts are generally driven by market and economic factors, while non-parallel shifts are more likely due to policy (including market structure) shifts.

Includes domestic corporate IPOs as of Dec. 31, 2012, excluding funds, LPs, SPACs, REITs and other trusts. 


\section{Country Ranks}

Ranking Based on Number of IPOs (Domestic Listings)
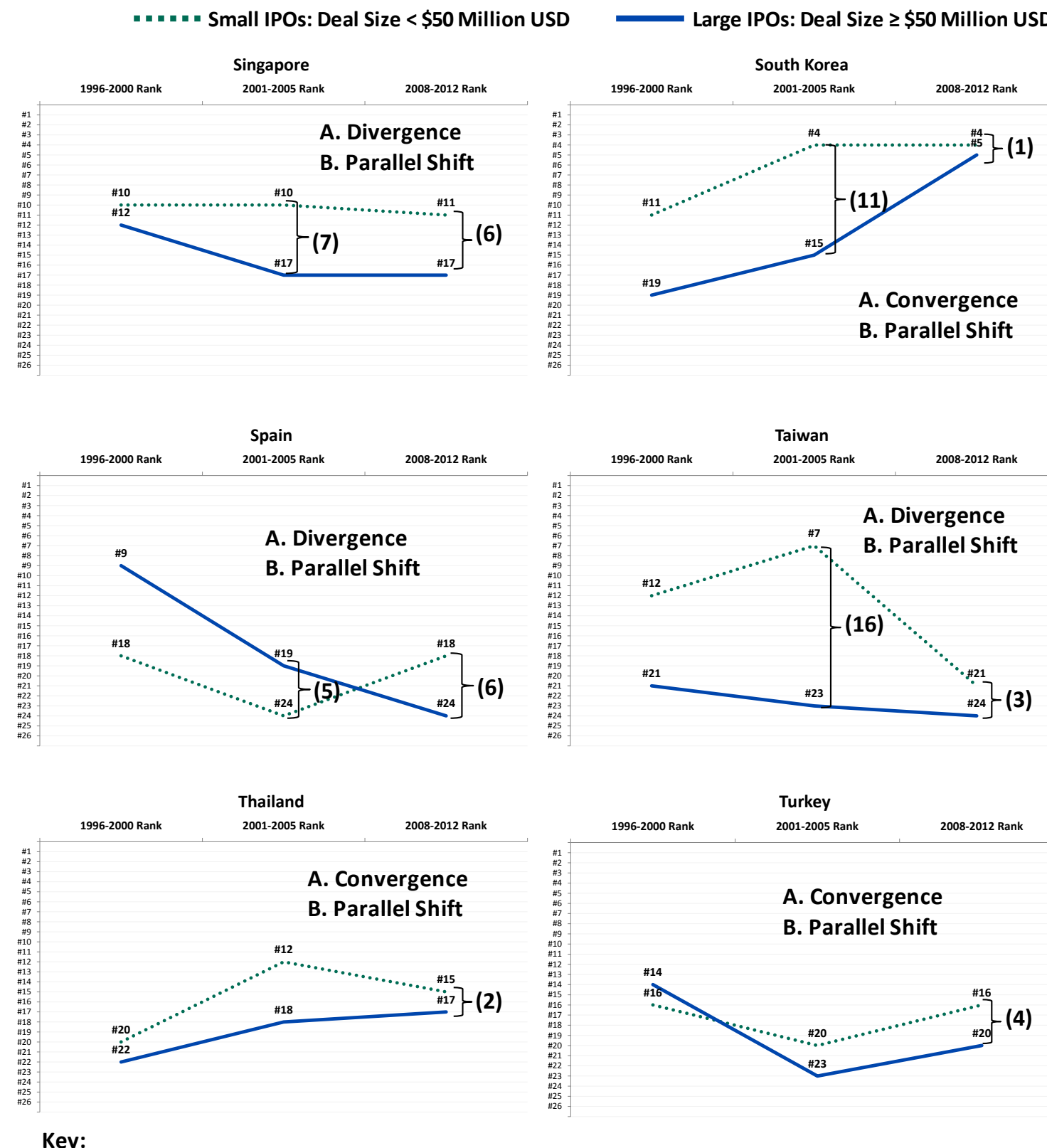

A. Convergence vs. Divergence: When policies and/or market structure equally favor (or disfavor) small and large IPOs, relative country rank will be similar (i.e., "convergence") for both the small and large IPO segments.

B. Parallel vs. Non-Parallel Shifts: Parallel shifts are generally driven by market and economic factors, while non-parallel shifts are more likely due to policy (including market structure) shifts.

Includes domestic corporate IPOs as of Dec. 31, 2012, excluding funds, LPs, SPACs, REITs and other trusts. 


\section{Country Ranks}

Ranking Based on Number of IPOs (Domestic Listings)

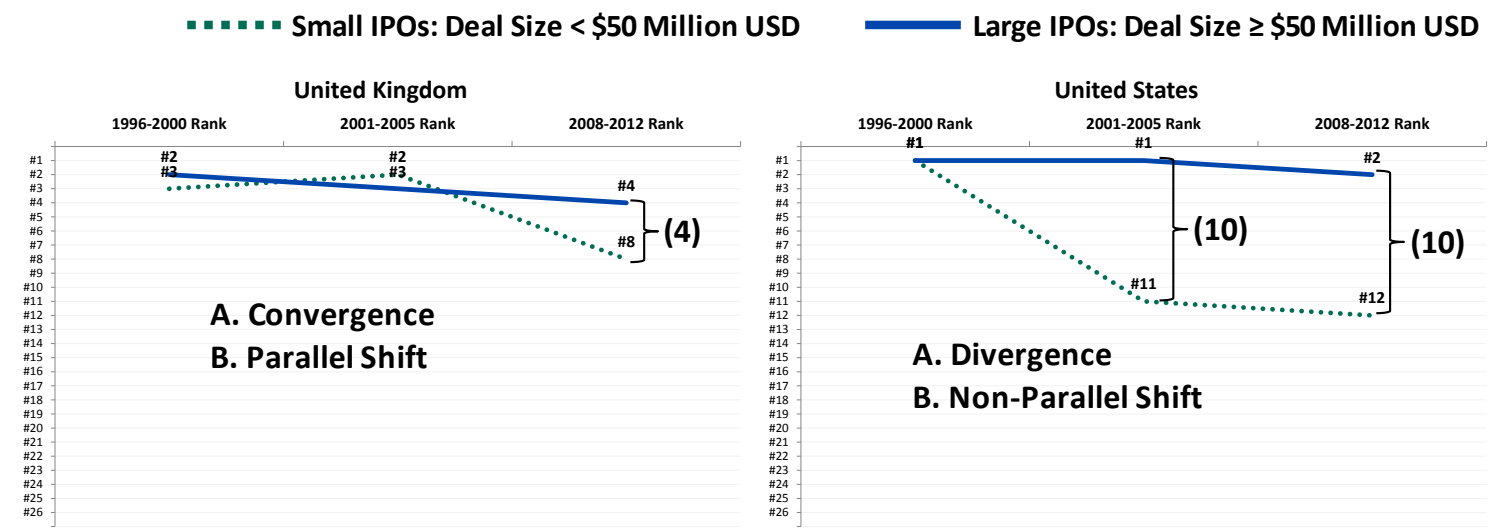

Key:

A. Convergence vs. Divergence: When policies and/or market structure equally favor (or disfavor) small and large IPOs, relative country rank will be similar (i.e., "convergence") for both the small and large IPO segments.

B. Parallel vs. Non-Parallel Shifts: Parallel shifts are generally driven by market and economic factors, while non-parallel shifts are more likely due to policy (including market structure) shifts.

Includes domestic corporate IPOs as of Dec. 31, 2012, excluding funds, LPs, SPACs, REITs and other trusts.

Sources: Weild \& Co., Grant Thornton LLP and Dealogic 
Absolute and GDP Weighted Rankings of IPO Production - Top 25 IPO Producing Countries Ranking Based on Number of IPOs (Domestic Listings)

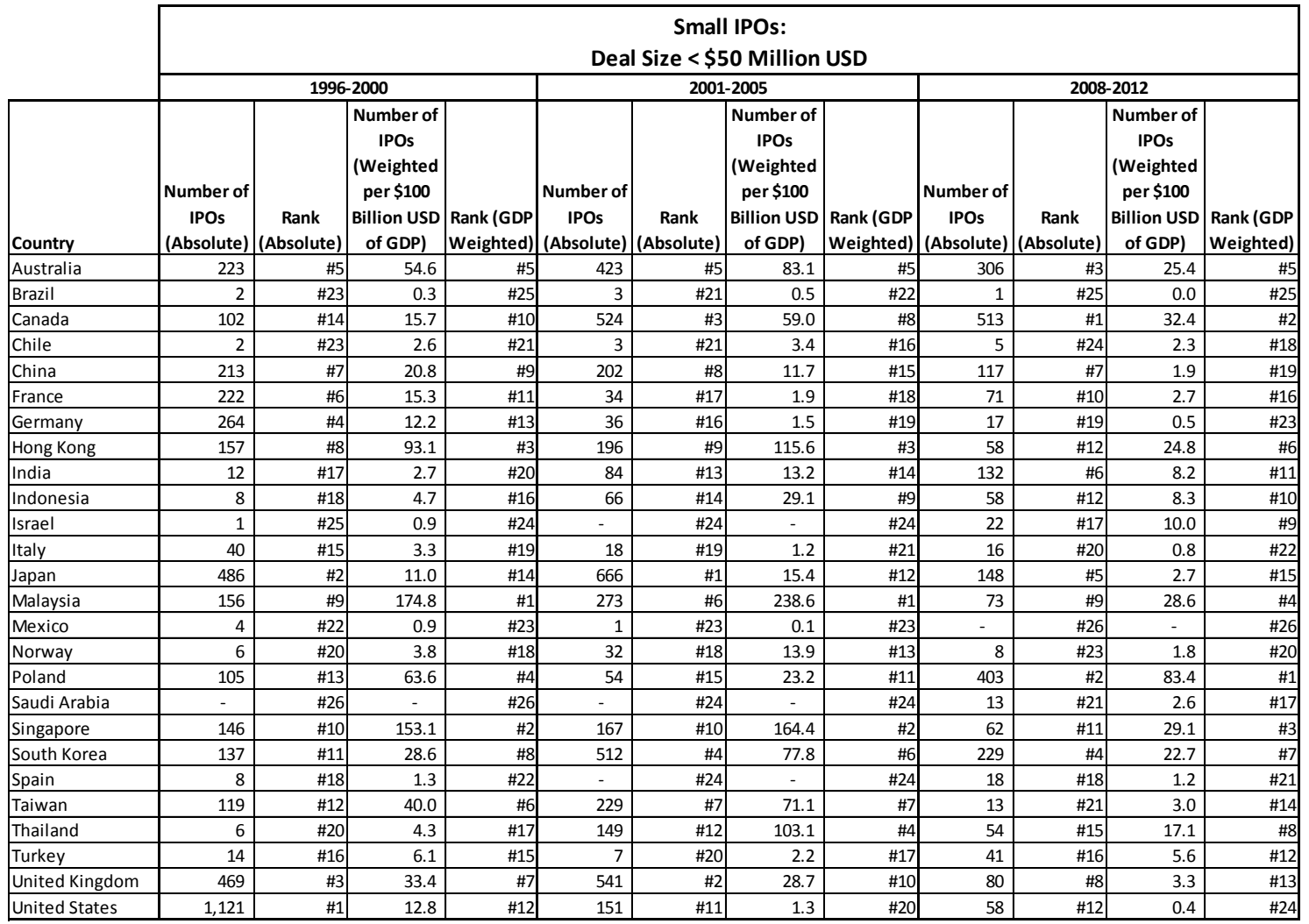

\begin{tabular}{|c|c|c|c|c|c|c|c|c|c|c|c|c|}
\hline \multirow[b]{3}{*}{ Country } & \multicolumn{12}{|c|}{$\begin{array}{c}\text { Large IPOs: } \\
\text { Deal Size } \geq \$ 50 \text { Million USD }\end{array}$} \\
\hline & \multicolumn{4}{|c|}{ 1996-2000 } & \multicolumn{4}{|c|}{ 2001-2005 } & \multicolumn{4}{|c|}{ 2008-2012 } \\
\hline & $\begin{array}{c}\text { Number of } \\
\text { IPOs } \\
\text { (Absolute) }\end{array}$ & $\begin{array}{c}\text { Rank } \\
\text { (Absolute) }\end{array}$ & \begin{tabular}{|c|} 
Number of \\
IPOs \\
(Weighted \\
per \$100 \\
Billion USD \\
of GDP) \\
\end{tabular} & $\begin{array}{l}\text { Rank (GDP } \\
\text { Weighted) }\end{array}$ & $\begin{array}{c}\text { Number of } \\
\text { IPOs } \\
\text { (Absolute) }\end{array}$ & $\begin{array}{c}\text { Rank } \\
\text { (Absolute) }\end{array}$ & \begin{tabular}{|c|} 
Number of \\
IPOs \\
(Weighted \\
per \$100 \\
Billion USD \\
of GDP) \\
\end{tabular} & $\begin{array}{l}\text { Rank (GDP } \\
\text { Weighted) } \\
\end{array}$ & $\begin{array}{c}\text { Number of } \\
\text { IPOs } \\
\text { (Absolute) }\end{array}$ & $\begin{array}{c}\text { Rank } \\
\text { (Absolute) }\end{array}$ & \begin{tabular}{|c|} 
Number of \\
IPOs \\
(Weighted \\
per \$100 \\
Billion USD \\
of GDP) \\
\end{tabular} & $\begin{array}{l}\text { Rank (GDP } \\
\text { Weighted) }\end{array}$ \\
\hline Australia & 26 & $\# 10$ & 6.4 & $\# 9$ & 73 & $\# 6$ & 14.3 & $\# 2$ & 21 & $\# 11$ & 1.7 & $\# 15$ \\
\hline Brazil & 7 & $\# 18$ & 0.9 & \#24 & 17 & $\# 12$ & 2.7 & $\# 15$ & 34 & \#8 & 1.6 & $\# 17$ \\
\hline Canada & 26 & $\# 10$ & 4.0 & \#15 & 129 & $\# 2$ & 14.5 & $\# 1$ & 36 & \#7 & 2.3 & $\# 13$ \\
\hline Chile & 2 & \#23 & 2.6 & \#17 & 5 & $\# 21$ & 5.6 & $\# 10$ & 8 & \#21 & 3.7 & $\# 10$ \\
\hline China & 149 & \#3 & 14.6 & \#3 & 100 & \#4 & 5.8 & $\# 9$ & 828 & $\# 1$ & 13.3 & $\# 1$ \\
\hline \begin{tabular}{|l|} 
France \\
\end{tabular} & 47 & $\# 7$ & 3.2 & $\# 16$ & 26 & $\# 8$ & 1.5 & $\# 20$ & 5 & $\# 23$ & 0.2 & $\# 26$ \\
\hline Germany & 142 & \#4 & 6.6 & \#8 & 20 & $\# 10$ & 0.8 & $\# 23$ & 13 & $\# 16$ & 0.4 & $\# 23$ \\
\hline Hong Kong & 36 & $\# 8$ & 21.3 & $\# 1$ & 23 & $\# 9$ & 13.6 & \#4 & 16 & \#14 & 6.8 & $\# 3$ \\
\hline India & - & $\# 25$ & - & $\# 25$ & 20 & $\# 10$ & 3.1 & $\# 13$ & 54 & $\# 3$ & 3.3 & $\# 11$ \\
\hline Indonesia & 14 & $\# 13$ & 8.3 & \#7 & 4 & $\# 23$ & 1.8 & $\# 19$ & 38 & \#6 & 5.4 & $\# 6$ \\
\hline Israel & 2 & $\# 23$ & 1.8 & $\# 20$ & 1 & \#26 & 0.8 & \#24 & 1 & \#26 & 0.5 & $\# 22$ \\
\hline Italy & 60 & \#6 & 5.0 & $\# 12$ & 31 & \#7 & 2.1 & $\# 17$ & 7 & $\# 22$ & 0.3 & $\# 24$ \\
\hline Japan & 91 & \#5 & 2.1 & $\# 19$ & 79 & \#5 & 1.8 & $\# 18$ & 25 & $\# 10$ & 0.5 & $\# 21$ \\
\hline Malaysia & 8 & $\# 17$ & 9.0 & $\# 6$ & 16 & $\# 13$ & 14.0 & $\# 3$ & 18 & $\# 12$ & 7.1 & $\# 2$ \\
\hline Mexico & 6 & $\# 19$ & 1.4 & $\# 21$ & 5 & \#21 & 0.7 & \#26 & 14 & $\# 15$ & 1.3 & $\# 18$ \\
\hline Norway & 9 & $\# 16$ & 5.6 & \#11 & 12 & $\# 16$ & 5.2 & $\# 11$ & 12 & $\# 17$ & 2.7 & $\# 12$ \\
\hline Poland & 10 & $\# 14$ & 6.1 & $\# 10$ & 15 & $\# 14$ & 6.5 & $\# 6$ & 18 & $\# 12$ & 3.7 & $\# 9$ \\
\hline Saudi Arabia & - & $\# 25$ & - & $\# 25$ & 7 & \#19 & 3.0 & \#14 & 31 & $\# 9$ & 6.1 & $\# 4$ \\
\hline Singapore & 17 & $\# 12$ & 17.8 & \#2 & 11 & \#17 & 10.8 & \#5 & 12 & \#17 & 5.6 & $\# 5$ \\
\hline South Korea & 6 & $\# 19$ & 1.3 & \#23 & 14 & $\# 15$ & 2.1 & $\# 16$ & 40 & $\# 5$ & 4.0 & $\# 7$ \\
\hline Spain & 29 & $\# 9$ & 4.8 & $\# 13$ & 7 & $\# 19$ & 0.8 & \#25 & 4 & \#24 & 0.3 & $\# 25$ \\
\hline Taiwan & 4 & \#21 & 1.3 & \#22 & 4 & $\# 23$ & 1.2 & \#22 & 4 & \#24 & 0.9 & $\# 20$ \\
\hline Thailand & 3 & \#22 & 2.2 & $\# 18$ & 9 & $\# 18$ & 6.2 & \#8 & 12 & \#17 & 3.8 & $\# 8$ \\
\hline Turkey & 10 & $\# 14$ & 4.3 & \#14 & 4 & $\# 23$ & 1.2 & $\# 21$ & 9 & $\# 20$ & 1.2 & $\# 19$ \\
\hline United Kingdom & 155 & $\# 2$ & 11.0 & \#4 & 121 & $\# 3$ & 6.4 & $\# 7$ & 41 & \#4 & 1.7 & $\# 16$ \\
\hline United States & 964 & $\# 1$ & 11.0 & \#5 & 458 & $\# 1$ & 4.1 & $\# 12$ & 323 & \#2 & 2.2 & $\# 14$ \\
\hline
\end{tabular}

Includes domestic corporate IPOs as of Dec. 31, 2012, excluding funds, LPs, SPACs, REITs and other trusts. 


\subsection{Trends and observations}

An examination of the IPO trends for all jurisdictions ${ }^{37}$ reporting listing activity reveals that (a) the dearth in activity in the United States is the largest contributor to the global decline in IPOs since 2001, while (b) Asian countries such as Hong Kong, China and South Korea have helped pick up some of the slack. From 2008 to 2012, China led the world with 945 public offerings ${ }^{38}$ that raised a total of USD 185.2 billion in proceeds. ${ }^{39}$ This is almost twice as high as the listing activity in the United States, which came in a distant second with 480 IPOs that raised USD 165.6 billion in proceeds during the same period, despite having the largest gross domestic product (GDP) of all jurisdictions.

Despite an increase in the number of IPOs within certain regions of the world, we find that there is a steady decline in the overall number of global public offerings. This downward trend is consistent with the findings in the April 2013 OECD working paper entitled "Who Cares? Corporate Governance in Today's Equity Markets" which utilized separate data sources to analyse trends in global listings.

Exhibit 7 shows global and U.S. IPO trends from 1993 to 2012, as compiled by the OECD. We believe these to be the most accurate numbers available and offer the following observations:

- The global number of IPOs declined from over 2000 per year in the early 1990s to less than 750 in 2012.

- $\quad$ The IPO decline is widespread and not confined to U.S. markets and therefore, likely precipitated by the proliferation of computer-based trading and low- transaction-costelectronic markets.

\footnotetext{
${ }^{37} 98$ jurisdictions reported public offerings for companies raising at least USD 5 million in proceeds from 1996 to 2012.

${ }^{38}$ Figures exclude IPOs raising under USD 5 million in proceeds.

${ }^{39}$ Figures for China exclude Hong Kong, China, which produced an additional 302 IPOs that raised a total of USD 140.7 billion in proceeds from 2008 to 2012 .
} 


\section{EXHIBIT 7}

\section{Global trends in primary equity markets}

Number of initial public offerings worldwide and the amount of equity raised by OECD and non-OECD corporations (2012 USD, billions)

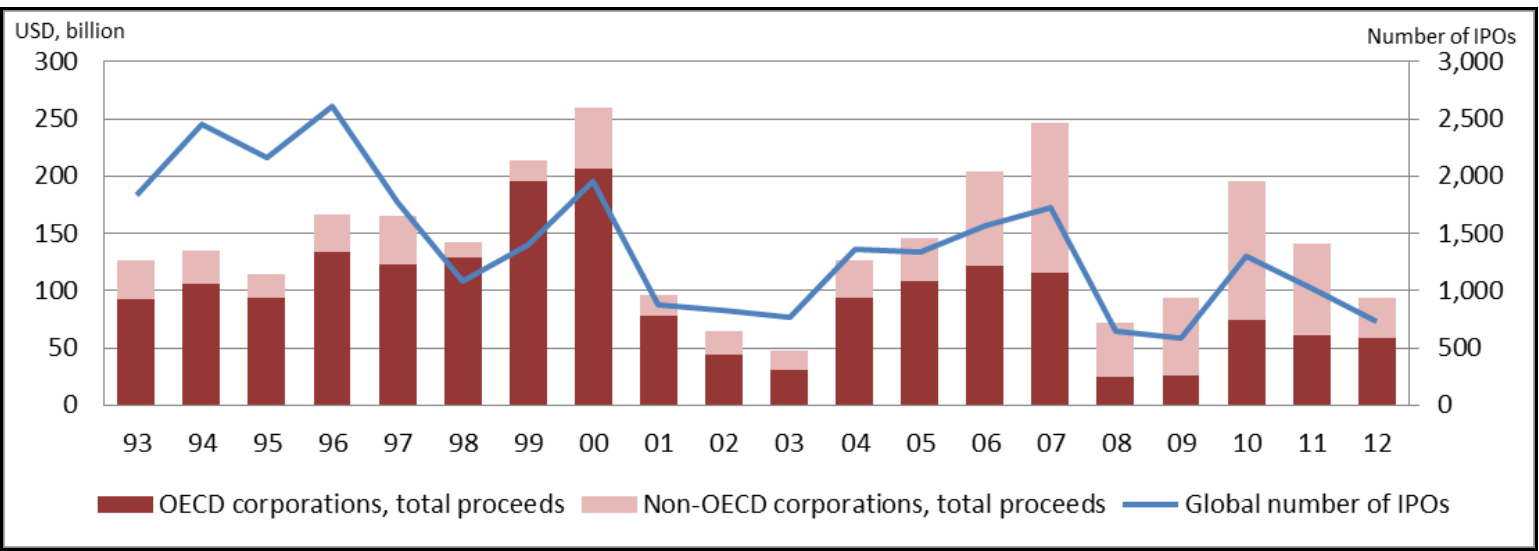

Trends in primary equity markets in the United States

Total number of initial public offerings, proceeds of US and non-US companies (2012 USD, billions)

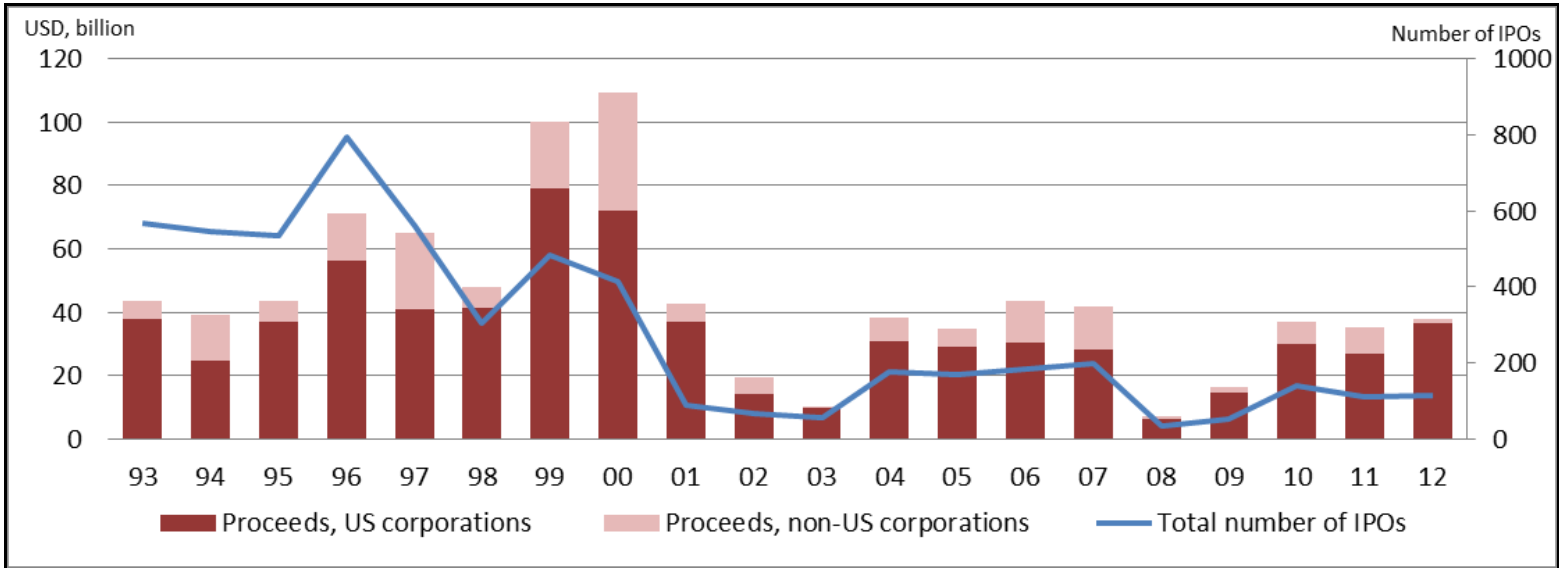


Since it is generally agreed by economists that the number of IPOs per year should grow at relatively the same pace as a country's economy, the size of a country's IPO market ceteris paribus should be comparable to that country's GDP size. To better illustrate this linkage, we examined the domestic ${ }^{40}$ IPO "efficiency rate" ${ }^{41}$ of the 26 jurisdictions in our sample set from 2008 to 2012 (see Exhibit 8). For example, with seventy domestic IPOs and an average annual GDP of USD 233.8 billion during this period, Hong Kong, China's domestic efficiency rate is 29.9 , the highest of the 26 jurisdictions we studied.

\footnotetext{
${ }^{40} \mathrm{An}$ IPO is classified as domestic when the nationality of the issuer is the same as the country of the exchange where the issuer went public.

${ }^{41}$ A domestic "efficiency rate" is defined as the ratio of a country's domestic corporate IPOs per USD 100 billion of that country's GDP.
} 


\section{EXHIBIT 8}

\section{Domestic IPO "Efficiency Rates" Vary Widely}

Domestic IPOs $\geq \$ 5$ Million USD

2008-2012

Quartile
\begin{tabular}{|l|r|}
\hline Fourth (Maximum) & 29.9 \\
\hline Third & 13.6 \\
\hline Second (Median) & 6.2 \\
\hline First & 2.6 \\
\hline
\end{tabular}

\begin{tabular}{|c|c|c|c|c|c|c|c|c|}
\hline Country & \begin{tabular}{l|} 
GDP CAGR \\
$2008-2012$ \\
\end{tabular} & $\begin{array}{c}\text { Efficiency } \\
\text { Ratio (IPOs per } \\
\text { \$100 Billion } \\
\text { USD of GDP) }\end{array}$ & Quartile & \begin{tabular}{|c} 
Total \\
Number of \\
IPOs \\
2008-2012 \\
\end{tabular} & $\begin{array}{c}\text { Number of } \\
\text { IPOs per } \\
\text { Year }\end{array}$ & $\begin{array}{c}\text { 个 } 1 \text { Quartile: } \\
\text { Number of IPOs } \\
\text { per Year? }\end{array}$ & $\begin{array}{c}\text { 个 } 2 \text { Quartiles: } \\
\text { Number of IPOs } \\
\text { per Year? }\end{array}$ & $\begin{array}{c}\text { 个 } 3 \text { Quartiles: } \\
\text { Number of IPOs } \\
\text { per Year? }\end{array}$ \\
\hline Hong Kong & $4.1 \%$ & 29.9 & Fourth & 70 & 14 & 14 & & \\
\hline Malaysia & $7.4 \%$ & 27.8 & Fourth & 71 & 14 & 15 & & \\
\hline Singapore & $12.6 \%$ & 24.4 & Fourth & 52 & 10 & 13 & & \\
\hline South Korea & $5.4 \%$ & 22.7 & Fourth & 229 & 46 & 60 & & \\
\hline China & $16.2 \%$ & 15.2 & Fourth & 945 & 189 & 371 & & \\
\hline Poland & $-2.9 \%$ & 14.5 & Fourth & 70 & 14 & 29 & & \\
\hline Thailand & $8.4 \%$ & 13.6 & Fourth & 43 & 9 & 19 & & \\
\hline Australia & $10.0 \%$ & 13.6 & Third & 164 & 33 & 72 & & \\
\hline Indonesia & $15.1 \%$ & 12.7 & Third & 89 & 18 & 42 & & \\
\hline Israel & $5.2 \%$ & 10.4 & Third & 23 & 5 & 13 & & \\
\hline India & $12.3 \%$ & 10.4 & Third & 167 & 33 & 97 & & \\
\hline Saudi Arabia & $8.4 \%$ & 8.7 & Third & 44 & 9 & 30 & & \\
\hline Turkey & $1.8 \%$ & 6.3 & Third & 46 & 9 & 44 & & \\
\hline Chile & $10.6 \%$ & 6.0 & Second & 13 & 3 & 6 & 13 & \\
\hline Canada & $4.2 \%$ & 5.2 & Second & 83 & 17 & 43 & 95 & \\
\hline United Kingdom & \begin{tabular}{l|l|}
$-2.1 \%$ \\
\end{tabular} & 3.8 & Second & 91 & 18 & 65 & 143 & \\
\hline Norway & $2.4 \%$ & 3.6 & Second & 16 & 3 & 12 & 27 & \\
\hline Taiwan & $4.3 \%$ & 3.5 & Second & 15 & 3 & 12 & 26 & \\
\hline United States & $2.4 \%$ & 2.6 & Second & 374 & 75 & 399 & 877 & \\
\hline Japan & $5.4 \%$ & 2.6 & First & 139 & 28 & 67 & 148 & 326 \\
\hline Brazil & $10.1 \%$ & 1.7 & First & 35 & 7 & 25 & 56 & 124 \\
\hline Mexico & $1.5 \%$ & 1.3 & First & 14 & 3 & 13 & 29 & 64 \\
\hline \begin{tabular}{|l} 
France \\
\end{tabular} & $-2.3 \%$ & 1.3 & First & 35 & 7 & 33 & 73 & 160 \\
\hline Italy & $-3.8 \%$ & 0.9 & First & 20 & 4 & 26 & 58 & 127 \\
\hline Spain & $-4.2 \%$ & 0.8 & First & 12 & 2 & 18 & 39 & 87 \\
\hline Germany & $\begin{array}{ll}-1.8 \% \\
\end{array}$ & 0.8 & First & 27 & 5 & 42 & 94 & 206 \\
\hline
\end{tabular}

${ }^{(1)}$ Note: Domestic IPO "Efficiency Ratios" and "Number of IPOs per Year" are likely below long term trends, since the period from 2008 to 2012 comes on the heels of the "Credit Crisis."

Includes domestic corporate IPOs with a deal value of at least $\$ 5$ million USD as of Dec. 31, 2012, excluding funds, LPs, SPACs, REITs and other trusts. 2012 estimate for gross domestic product (GDP).

\section{Sources: Weild \& Co., Grant Thornton LLP, Dealogic, the World Bank and The World Factbook}

After segmenting each country's efficiency rate into quartiles, we asked "how many IPOs should each country hypothetically be doing every year, if we were to increase each country's efficiency rate by at least one quartile?" The United States, which placed in the bottom of the second quartile with an average of seventy-five domestic IPOs per year and an efficiency rate of 2.6, would generate 399 IPOs per year, if it were to increase its efficiency ratio by one quartile, and 877 IPOs, if it were to increase its efficiency ratio by two quartiles.

Remarkably, this estimate for the United States is on par with the results of a separate analysis we conducted previously, where we examined the number of companies that should have gone public if the U.S. IPO market had grown in line with the U.S. GDP rate of $3 \%$ year 
from the early 1990s to the present. Using this metric, the United States should have generated at least 950 IPOs per year, beginning in 2011.

We believe that increasing aftermarket incentives will serve to drive up a country's IPO rates, which will in turn, increase a country's GDP. It should also be noted that each country's domestic IPO efficiency ratio, as well as its number of IPOs, is likely below that of long term trends, since the period we studied comes on the heels of the World Financial Crisis of 2007-2008.

\subsection{Role in job creation and economic growth}

\subsubsection{Direct job formation and the multiplier effect}

We estimate that, if not for the scarcity in public offerings, 3.1 million to 9.4 million additional jobs might have been created in the United States by companies after going public. However, if we assume a "multiplier effect" where higher IPO activity accounts for a like-kind number of jobs created in the private market (a conservative effect of only one for one), the range of 3.1 million to 9.4 million jobs jumps to between 6.2 million and 18.8 million jobs created. (See Exhibit 9).

\section{EXHIBIT 9}

\section{A major contributor to employment}

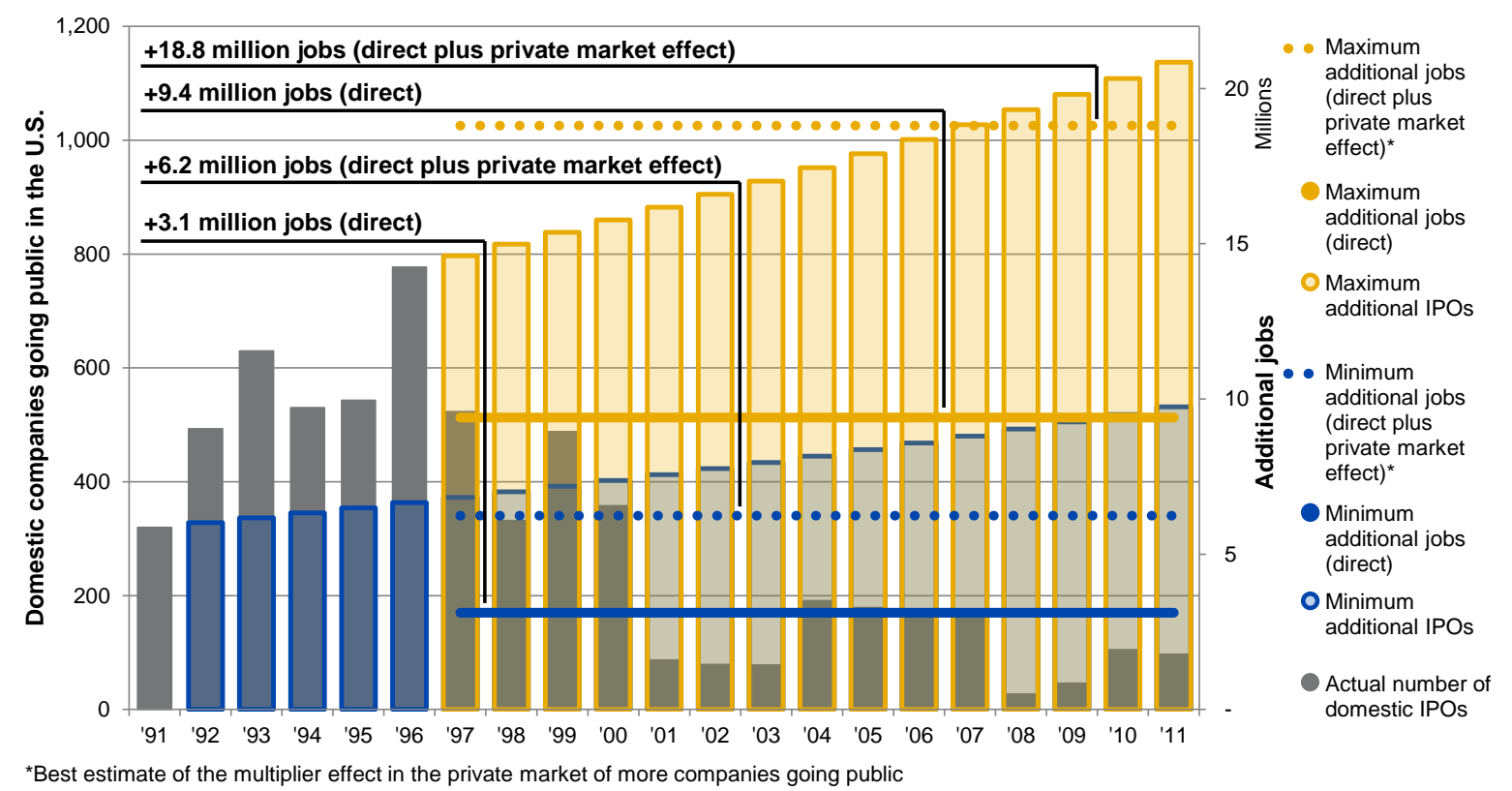

Sources: Grant Thornton LLP, Dealogic and the U.S. Department of Commerce Bureau of Economic Analysis

Domestic corporate companies going public in the U.S. as of Dec. 31, 2011, excluding funds, REITs and other trusts, SPACs and LPs. Assumes an annual growth rate of $2.57 \%$ (U.S. real GDP growth, 1991-2011) and 822 jobs created on average post-IPO (see "Post-IPO Employment and Revenue Growth for U.S. IPOs," Kauffman Foundation).

\subsubsection{Types of jobs}

In fact, the so-called "multiplier effect" may be much larger than we estimate above. Professor Enrico Moretti, from the University of California at Berkeley, has estimated that as many as five local service sector jobs, ranging from doctors and teachers to wait staff and 
sales clerks, are created for every one technology and biotechnology sector job produced. ${ }^{42}$ These are the very industries that once sought out public offerings as their preferred strategy to raise capital (and exit). This five-to-one ratio of job formation has served to increase the number of employment opportunities at all skill levels and ultimately, the U.S. standard of living.

\subsubsection{Alternative ways to raise capital and their impact on growth}

Given the current structural deficiencies in the U.S. stock market, a merger or an acquisition is now the exit strategy of choice for many small companies that previously would have chosen to go public. When these companies cannot raise capital effectively through the IPO market and must look to a sale of their business, jobs are generally lost, not gained. This creates an opportunity cost as acquirers rationalize businesses, cut costs and lay off workers.

It is not uncommon to hear challenges that the decrease in the numbers of IPOs is a misplaced concern, because alternative sources of capital have arisen to take the place of the IPO market. In fact, these challenges offer no compelling data to back up their claims. The two most prominent theories maintain that the private equity market or the equity private placement markets have displaced the IPO market in fund raising.

However, these arguments do not hold up when one considers that i) the private equity industry is largely confined to positive cash flowing companies (not venture capital companies) and ii) that venture-capital backed IPO exits are depressed, despite unprecedented amounts of venture capital invested, while the "gestation period" time-to-IPO for venture-backed companies more than doubled from 4.5 in 1998 to 9.6 years in $2008 .{ }^{43}$ Finally, the IPO Crisis Task Force was led by Kate Mitchell, a former National Venture Capital Association (NVCA) Chairman. Clearly, if the venture capital industry in the United States had been enjoying "alternatives," it would not be spending its time trying to fix the IPO market.

\footnotetext{
42 See Moretti, E. (2013), The New Geography of Jobs, New York.

${ }^{43}$ NVCA 4-Pillar Plan to Restore Liquidity in the U.S. Venture Capital Industry, 29/30 April 2009, see slide 7 at http://www.slideshare.net/NVCA/nvca-4pillar-plan-to-restore-liquidity-in-the-us-venture-capital-industry1360905.
} 


\section{KEY FACTORS IN EFFECTIVE STOCK MARKETS (SUPPORTING ECONOMIC GROWTH AND DEVELOPMENT)}

\subsection{Balancing of interests}

A capital market is a multi-layered, complex ecosystem of competing and related interests. There are numerous constituents, each of whom must be governed by rules and encouraged by incentives. Those markets that succeed in balancing these many interests are those markets that ultimately will go the farthest in facilitating capital formation.

If the rules become too burdensome, or if the incentives become diminished for any party, the ecosystem will operate far below its potential efficiency. Companies will have difficulty reaching new investors, innovation and job creation will slow or stop altogether, and the macroeconomy will suffer. A vibrant capital market is the engine of a healthy economy (consider what has happened in the United States, comparing the market today versus the market twenty years ago, i.e., before Regulation ATS, before penny tick sizes and before the proliferation of HFT).

What are the successful ingredients of a healthy ecosystem?

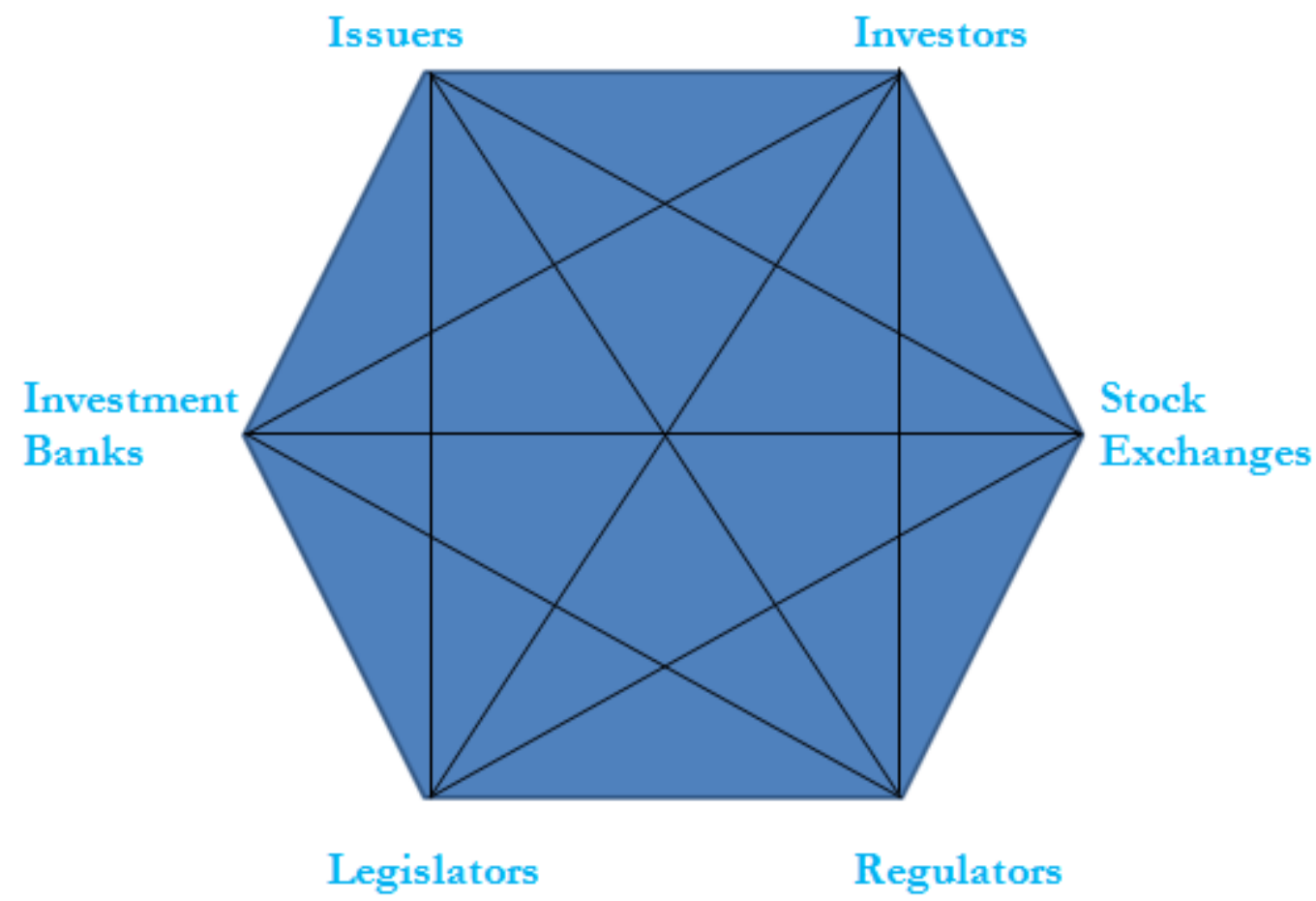

The issuers themselves may actually be in the least powerful position in the ecosystem. The entrepreneurs and venture capitalists, who seed the initial growth, all obviously wish to succeed, but their success is not entirely in their hands. They must have a viable public market as a target option. They must be able to reach fundamental institutional investors 
who have aligned interests and time horizons. They must be able to reach retail investors who place limit orders with the confidence that those orders will be routed fairly and not gamed by HFT firms.

The legislators and regulators are the critical foundation of this ecosystem. There are those who view these agencies as burdensome or interfering, and clearly there are examples when each has overstepped its boundaries. But no system can be successful without thoughtful, measured, far-sighted decision-making by these parties. "Laissez-faire" simply does not work here; the system is too important to the macroeconomy to be allowed to operate without the leadership and guidance of the lawmakers and policymakers, and these parties cannot make those decisions properly without considerable and considered input from the rest of the ecosystem.

We would urge legislators and regulators to hold each other accountable on a regular basis through reviews and analysis of market statistics and surveillance. We would urge legislators to support additional funding to be directed to regulators to improve staffing and education.

There are those who place much of the blame for market crises at the feet of investment banks. But these intermediaries are critical for the system to function efficiently. Banks can be viewed as the central conduit of information and capital, and they will be successful if the legislators and regulators maintain appropriate risk management measures while, at the same time, providing an incentive system that makes economic sense.

In this vein, we believe two measures would go a long way toward making banks more efficient globally:

1) Legislators and regulators should examine the role of banks in operating their own dark pools. There are inherent conflicts of interest here, and markets would be better served if the pool operators were independent of investment banks.

2) Tick size regimes should be examined to improve efficiency. In the U.S., as of March 2013, the SEC is strongly considering the initiation of a pilot program of expanded tick sizes across a range of stocks. We believe that every market would benefit from studying whether they have the appropriate tick sizes in place, and whether these tick sizes should be flexible based on liquidity and other measures.

Investors-both institutional and retail-benefit from access to management of companies in which they have an interest. The earlier this direct access can happen, the better it is for both company and investor, with the likelihood of a longer-term, meaningful investment increasing.

Here, investment banks can play an active role as intermediary. But banks will only be active in this if they are properly incented to do so, and the economics of high turnover, short-term-focused accounts make it impractical for banks to commit resources to long-term, fundamental investors. This is where the need for increasing tick sizes can also apply.

Stock exchanges play a critical role in the maintenance and growth of the ecosystem. There was a time when all exchanges were member-owned and served the public interest. This is no longer the case in most of the leading economies in the world. Exchanges are forprofit enterprises, which must serve the needs of their shareholders first, while their clientsthe corporate issuers-take a back seat. 
While we admit it would be nearly impossible to turn back the clock and make exchanges not-for-profit agencies again, there are measures that countries can adopt that would serve the public interest.

Legislators and regulators should examine the ever-expanding role of ETFs and indexing in the market. The exchanges are rapidly listing more and more of these derivative products, while for the most part, languishing in new corporate listings.

In addition to examining the role of investment banks and their dark pools, legislators and regulators should put HFT firms under the microscope. Should these firms be allowed to operate their own dark pools? Should these firms be allowed to step in front of legitimate investor orders for fractions of a penny? Should these firms be allowed to cancel orders immediately after placing them?

Clearly the answer to all of these questions, in our view, should be a resounding NO. None of these activities do anything to facilitate capital formation, while all of these activities have the potential to undermine the very foundation of the ecosystem. 


\section{INITIATIVES IN OTHER AREAS OF THE WORLD-OUR TAKE AND WORDS OF CAUTION $^{44}$}

The International Organization of Securities Commissions (IOSCO) recently published (March 2013) for public comment a "Consultation Report" entitled, Regulatory Issues Raised by Changes in Market Structure ${ }^{45}$ While the report opens by acknowledging a request to IOSCO by the G20 leaders to 'develop...recommendations to promote markets' integrity and efficiency to mitigate the risks posed to the financial system by the latest technological developments" and the report points to need for regulators to "continuously evaluate" fragmentation, technological developments and evolving trading strategies including algorithmic and HFT, ${ }^{46}$ the report fails to tackle what we have identified as the three most pressing questions: (i) Is the current evolution of market structure adding to the world's systemic risk (as evidenced by asset price correlations, industry price correlations, trading during the World Financial Crisis or the Flash Crash)?, (ii) Is the current evolution of market structure undermining capital formation and the world's economies (since 1993, the number of global IPOs has declined significantly ${ }^{47}$ )?, and (iii) If the answer to either of the prior questions is "yes," what measures is IOSCO recommending be taken to reverse these trends?

The following is a brief review of other notable market structure initiatives in a variety of jurisdictions.

\subsection{United Kingdom}

In July 2011, one of the authors of this study visited with the London Stock Exchange (LSE) and a number of UK LSE AIM-focused market makers and institutional investors. We were told by UK-based market participants that the LSE had been promoting the larger, more liquid AIM stocks out of the quoted market making system (SEAQ) and into the electronic order book. This had the effect of siphoning off economics from the dealers. In Exhibit 10, the United Kingdom shows a lower IPO efficiency rate given the percentage of nanocap (sub USD 100 million in market value) stocks that offer greater than $1 \%$ tick size as a percentage of share price.

However, this simple analysis does not show the whole picture: over $50 \%$ of UK stocks offer less than $0.1 \%$ tick size as a percentage of share price. The UK markets, despite their reputation for having an enlightened alternative regime for smaller companies is, it appears,

\footnotetext{
${ }^{44}$ As of March 2013. There have been subsequent developments which are beyond the scope of this study.

${ }^{45}$ See www.iosco.org/library.

${ }^{46}$ OICU-IOSCO (2013), Regulatory Issues Raised by Changes in Market Structure, Consultation Report, March, see p. 22.

${ }^{47}$ See Figure 2.2 "Global trends in primary equity market", Isaksson, M. and S. Çelik (2013), "Who Cares? Corporate Governance in Today's Equity Markets", OECD Corporate Governance Working Papers, No. 8, OECD Publishing.
} 
under-incentivizing liquidity providers and thus paying the price in reduced capital formation and associated economic growth.

\subsubsection{The Kay Review ${ }^{48}$}

Professor John Kay was commissioned by the Secretary of State for Business, Innovation and Skills to review UK equity markets with a view to understanding whether they gave sufficient support to achieve long-term financial goals. The review is a broad based critique of UK equity markets and many of its criticisms could also be levied at most of the world's other major markets. It cites a lack of alignment of incentives in the equity investment chain that has caused excessive short-termism, including a lack of long-term constructive human engagement between investors and managements.

Professor Kay acknowledges the decline in primary equity capital formation and shares many oft-cited reasons for its decline, including the rise of private equity (which we dispute in part earlier in this study). It is not clear to us how any of the "Kay Review Recommendations" for better behaviour would be achieved.

In reading Professor Kay's review, however, we are struck that the misalignments in the equity investment chain are likely greatly exacerbated by, and in many instances caused by, low-cost electronic trading (including cross-linking of markets and asset classes), which incentivizes short-termism and, at the same time, undermines the broad based fundamentally-oriented distribution that is essential to primary capital formation and a successful IPO market.

The most straight forward and effective mechanism to achieve Professor Kay's objectives for better alignment would be to simply raise tick sizes and commissions, which would dampen trading (short-termism) and force a realignment to long-term investing and capital formation. An alternative would be a so-called "transaction tax," but such a tax would only siphon monies from the system, potentially underfunding the ecosystem to support fundamental research and investment disciplines. Higher tick sizes and commissions on stocks would also increase the incentives to broker individual stocks, which would lessen the trend towards "intermediation" of stock ownership through "wrap" products, asset managers, ETFs and other structures that are designed to replace fees that were lost through the decline in tick sizes and brokerage commissions in electronic markets.

\subsubsection{The Government Response to the Kay Review ${ }^{49}$}

The UK government endorses most of the recommendations of the Kay Review, which are so broad based and general as to, on some level, make the authors wonder how an effective implementation plan can be devised that will address what we believe is the major root cause of short-termism - the enablement created by low-cost electronic trading, cross linkages of asset classes and markets, and the accompanying use of derivatives ("intermediation"), such as ETFs, to displace fundamental investment.

When investment managers and investment themes are increasingly structured to make use of a current market structure which places a premium on speed, low cost, themes (via ETFs and other strategies) and trading, how likely is it that the Kay Review and the

\footnotetext{
${ }^{48}$ See http://www.bis.gov.uk/assets/biscore/business-law/docs/k/12-917-kay-review-of-equity-markets-finalreport.pdf.

${ }^{49}$ See http://www.bis.gov.uk/assets/biscore/business-law/docs/e/12-1188-equity-markets-support-growthresponse-to-kay-review.pdf.
} 
Government's Response will materially alter behavior in ways that will shift the investment focus back to long-term (real) growth? We therefore find the recommendations, and the Government's response, to be constructive, but likely insufficient. Recommendations to reverse mandatory reporting (IMS or "Interim Management Statements") and to remove barriers for individuals to own stocks, while certainly constructive, seem to ignore the old adage that, "Stocks are sold, they're not bought" and that low-transaction cost market structures disfavour the investment in infrastructure required to support fundamentallyoriented, long-term, single stock investing, especially in small capitalization (less naturally visible) stocks.

\subsubsection{BIS Initiative on making companies more accountable to shareholders and the public ${ }^{50}$}

We are struck by the increasing lack of balance in these discussions. Issuers are notoriously ineffective at advocating for their own interests in capital markets structure. We believe that the question also needs to be asked, "How can shareholders (now increasingly short-term traders) and market structures be more aligned (accountable) to the long-term needs of companies and their managements?"

As stock markets, including the LSE, have become public, for-profit entities, and the number of competing alternative trading venues has increased, trading and investment interests dominate the discussion and the voice and interests of issuers-historically represented to the market and Government by member-owned stock exchanges-are increasingly silenced.

\subsubsection{Foresight Project on the future of computer trading in financial markets ${ }^{51}$}

The Foresight Project is an important work in that it raises critical issues. It warns that computer-based trading (CBT) and the use of HFT can lead to "significant instability," including a greater potential for periodic illiquidity and self-reinforcing feedback loops. The Foresight Project also specifically highlights the risk that "...unexpected and risky events (such as extremely rapid crashes) come to be seen as increasingly normal, until a disastrous failure occurs."

Unfortunately, this work and the Kay Review seem mostly to exist independently. We think both groups might be encouraged to collaborate and inform one another. Further, and most troubling, we could not find an in-depth discussion of how small tick sizes and CBT impact capital formation and short-termism in the Foresight Project. Even Chapter 6, which is entitled, "Economic impact assessments on policy measures," is silent on this subject and thus we find the Foresight Project incomplete.

In fact, of the many "Annex Project Reports and Papers" (more than fifty), none specifically address this issue. We did, however, find one line from report EIA7, entitled Tick size regulation: costs, benefits, and risks, that states, "If the tick size for small companies is too small, a lack of liquidity for smaller stocks could inhibit the founding of new companies and thus inhibit economic growth."

\footnotetext{
${ }^{50}$ See https://www.gov.uk/government/policies/making-companies-more-accountable-to-shareholders-and-thepublic.

${ }^{51}$ See http://www.bis.gov.uk/foresight/our-work/projects/current-projects/computer-trading.
} 


\subsubsection{Bold action to open up London's equity markets to high-growth companies $^{52}$}

The UK Department of Business Innovation \& Skills announced proposals with the LSE to create a new route to the UK IPO market for high-growth companies. We suspect that unless the BIS, LSE and FSA address the micromarket structure and the underlying incentives to distribute and support companies once they are listed, that the effect will be similar in some respects to Title 1 of the JOBS Act in the United States and the so-called "IPO On Ramp." It will attract new companies to list, but the micromarket structure may not provide the required aftermarket support, thus causing IPO "windows" to close prematurely and further stunting any growth in listings.

\subsection{European Commission}

Generally speaking, we are impressed with the fact that the European Commission recognizes the need to support both SMEs and long-term finance.

\subsubsection{Review of the Markets in Financial Instruments Directive e $^{53}$}

The European Commission has noted that SMEs have greater difficulties and higher costs in accessing financial markets than larger issuers. It states that these difficulties are related to a lack of visibility and market liquidity for SME shares (we generally agree) and has suggested two options: (i) to introduce a "tailored regime" for SME markets or (ii) to promote an "industry led regime" to enhance the visibility of these markets.

It appears that the European Commission has acted on neither of these proposals, and we can find no evidence that it has specifically considered the impact of low-cost computerbased market structures on the economic incentives required to sustain visibility and liquidity in SMEs. The two specific recommendations, as taken from the report, include:

1.6 Introduce a tailored regime for SME markets under the existing regulatory framework of MTF [Multilateral Trading Facilities]. Under this option a special category of SME market would be established in MiFID, under the existing regulatory framework of MTF, specifically designed to meet the needs of SME issuers. Such a regime would entail more calibrated elements in relation to the eligibility of SME issuers facilitating access of SMEs to MTFs while still creating a unified European quality label for SMEs providing for more visibility and therefore more liquidity in SME stocks.

1.7 Promote an industry-led initiative to enhance the visibility of SMEs markets. In this option, instead of setting up an EU harmonized regulatory framework for SME markets, an industry-led initiative could be promoted developing market standards leading to a harmonized appearance of SME markets and finally networks between SME markets across the EU. The industry may, according to SMEs' and investors' demand and needs, create a self-regulated standard model taking into account existing market models and practises. This would entail to give some incentives to SME markets at EU

\footnotetext{
${ }^{52}$ See http://news.bis.gov.uk/Press-Releases/Bold-action-to-open-up-London-s-equity-markets-to-high-growthcompanies-6805e.aspx.

${ }^{53}$ See http://ec.europa.eu/internal market/securities/isd/mifid en.htm.
} 
level (e.g., communication, financing) to enhance their visibility and promote a European network of SME trading venues."

\subsubsection{Green paper on long-term financing ${ }^{55}$}

A so-called "Green Paper" was launched by the European Commission on 25 March $2013,{ }^{56}$ to create a "...three-month public consultation on how to foster the supply of longterm financing and how to improve and diversify the system of financial intermediation for long-term investment in Europe." Here, the focus is on extremely long-term projects, including "...energy, transport and communication infrastructures, industrial and service facilities, climate change and eco-innovation technologies, as well as education and research and development." There is also mention of the financing needs of SMEs as deserving "...particular attention as they have the potential to underpin long-term growth."

We would submit to the European Commission that low-cost and associated CBT (computer-based trading) deprives stock markets of the economic incentives required to write and disseminate long-term fundamental research, tell long-term stories to investors and to provide capital and to solicit interest to support institutional liquidity. We believe that higher tick sizes and/or commissions will be essential ingredients to promote and sustain long-term investment.

\subsection{Australia}

\subsubsection{Consultation on key market structure reforms ${ }^{57}$}

The Australian Securities \& Investment Commission (ASIC) seems to focus little attention to the long-term investment and SME issues that are the focus of other markets and instead, seems to devote most of its attention to "market integrity" around trading issues. Specifically, their area of focus includes:

- market operator systems and controls

- $\quad$ extreme price movements

- enhanced data for market supervision, and

- $\quad$ pre-trade transparency.

\subsubsection{Higher tick sizes}

As seen elsewhere in this study, Australia permits higher tick sizes as a percentage of share prices to support SMEs and is enjoying higher output of IPOs, when adjusted for the size of their economy.

\footnotetext{
${ }^{54}$ See http://ec.europa.eu/internal market/securities/docs/isd/mifid/SEC 20111226 en.pdf.

55 See http://ec.europa.eu/governance/impact/planned ia/docs/2013 markt 018 long term finance en.pdf.

${ }^{56}$ See http://europa.eu/rapid/press-release IP-13-274 en.htm.

${ }^{57}$ See http://www.asic.gov.au/asic/asic.nsf/byheadline/12-

143MR+ASIC+consults+further+on+key+market+structure+reforms?openDocument.
} 


\subsection{China}

\subsubsection{To develop a more open and inclusive capital market ${ }^{58}$}

China has a different set of issues as an emerging growth economy under one party rule. Culturally, the Chinese population has a reputation for speculative investing (and gambling). This is reflected in SME prices. They also save at high rates: USD 4 trillion annually, according to Guo Shuqing, Chairman of the China Securities Regulatory Commission (CSRC), in his address to the Asian Financial Forum in Hong Kong, China on 14 January 2013.

As a consequence, retail investors account for a staggering $80.9 \%$ of total trading volume. China has largely taken a top-down approach to constructing stock markets in the last twenty years, first to accommodate mostly larger state-owned enterprises, and as time went on, to broaden its infrastructure (and capacity) to accommodate more SMEs. For example, the ChiNext stock market, which caters to smaller companies, was not opened until 2009 by the Shenzhen Stock Exchange, and the CSRC has recently discussed its interest in developing a national SME stock transfer system or the so-called "new third board."

While China underperforms in the production of small IPOs given the size of its aftermarket incentive tick-size structure, we see this as limited by capacity and prioritization and expect that this performance gap that will be closed over time.

\subsection{Canada}

\subsubsection{Consultation on electronic trading and direct electronic access to marketplaces $^{59}$}

Canadian regulators grapple with many of the same issues as U.S. regulators when it comes to trading in large capitalization stocks, due in part to the proximity of the two nations and the steady dialog that has occurred between the SEC and the Ontario Securities Commission (OSC).

Many issues were raised by the Flash Crash on 6 May 2010, and Canadian regulators have recognized that the "...speed and complexity of trading require a greater focus on controls designed to mitigate the risks of these technological changes."

Canada has a history of catering to SMEs in public markets, beginning with the Vancouver Stock Exchange, which first opened in 1907. After over ninety years of operation, it was merged into the Canadian Venture Exchange in 1999 and ultimately acquired by The TSX Group (now known as The TMX Group, which operates the Toronto Stock Exchange and other exchanges) in 2001.

In July 2012, the OSC continued this tradition by launching the OSC SME Institute for Small and Medium Enterprises. ${ }^{60}$ While Canada has produced an exceptional number (for the size of its GDP) of small IPOs, it has also enjoyed an ecosystem and investment culture that was once supported by quote-based dealer markets that were more SME-friendly than

\footnotetext{
${ }^{58}$ See http://www.csrc.gov.cn/pub/csrc en/Informations/phgall/201301/t20130114 220401.htm.

${ }^{59}$ See http://www.osc.gov.on.ca/en/SecuritiesLaw ni 20110408 23-103 pro-electronic-trading.htm.

${ }^{60}$ See http://www.osc.gov.on.ca/en/NewsEvents nr 20120704 osc-sme-institute.htm.
} 
current electronic order-book and auction markets. Higher tick sizes seem to still sustain higher small IPO rates (see Exhibit 10), though we do have concerns that the Canadian convergence to electronic market structure will take a toll on SMEs, resulting in higher numbers of delistings. 


\section{THE ECONOMY: DRIVING GROWTH}

\subsection{What changes stimulate or depress equity capital formation}

Here we provide an overview of macroeconomic and other factors that drive money flows into stocks. As money flows in and out of stocks, it affects stock prices. Stock prices determine cost and availability of equity capital, which ultimately drives the equity new issues market (equity capital formation). However, share price may be even more important to the success of small companies that depend on the equity capital markets to fund growth, because, by contrast, large companies tend to have significantly greater ability to finance with debt capital.

Micromarket structure will, in large part, determine the relative liquidity, visibility and transaction costs of naturally illiquid stocks (generally smaller stocks). By contrast, large capitalization stocks are innately visible and liquid (network effect) and micromarket structure will largely determine only transaction costs. We believe that policymakers fail (with some exceptions) to adequately make this critical distinction in market design: That naturally illiquid (small) and liquid (large) stocks require different market structures, policies and incentives, and pose different risks when they get it wrong. Improperly conceived small company markets curtail access to capital and will drag on the economy (e.g., the current U.S. stock market structure that has caused a drop off in small IPOs ${ }^{61}$ ). Improperly conceived large company markets have and will exacerbate volatility, enable bubbles and undermine investor confidence (e.g., the Dot Com Bubble and the so-called Flash Crash).

The analysis on economic incentives in the aftermarket will raise as many questions as it answers. There is a wide diversity of share price conventions and economic incentives at work across the 26 jurisdictions studied. Our ability to investigate and document the micromarket structure and policies in each of the 26 jurisdictions was constrained by time, resources and lack of access to local experts, and thus indicates areas for future research.

We believe, however, that there is a clear indication that higher economic incentives to support the aftermarkets of smaller capitalization stocks are linked to larger numbers of IPOs and that the decline of the small IPO in the United States, and the relative size of the small IPO market in all countries, is likely driven by micromarket structure (i.e., aftermarket incentives) and the absolute size of the economy, because larger economies support larger numbers of public companies.

\footnotetext{
${ }^{61}$ See Weild, D., E. Kim and L. Newport (2012), "The trouble with small tick sizes", Capital Markets Series, Grant Thornton LLP, http://www.sec.gov/info/smallbus/acsec/acsec-backgroundmaterials-090712-weildarticle.pdf.
} 


\subsubsection{Some factors that impact stock market based economic activity}

Money flows

Major shifts in money flows from central banks to the capital markets and from one asset class to another will generally create a backdrop for a rise or fall in stock prices. However, in low transaction-cost micromarket structures, computer-based information mining strategies are favoured over high-transaction-cost, information-additive strategies (research-based stock picking) and we would thus expect money flows to favour larger stocks to the detriment of smaller stocks and capital formation. As a consequence, policymakers must exercise a deft hand in the creation of incentive structures to sustain interest in small company stocks, capital formation and job growth.

\section{Interest rates}

Low interest rates are the hallmark of stimulative monetary policy. Low interest rates will flood markets with cash and may lead to bubbles. The direction of movement of interest rates may be more important than absolute interest rates, in that it will cause investors to modify strategies, which in turn will lead to shifts in money flows. For example, an increase in interest rates will cause bond portfolios to lose value and bond investors to shift assets into other asset classes including equities. Thus, stock prices may rise in the face of increasing interest rates. ${ }^{62}$

\section{Regulated use of leverage}

In the wake of the Financial Crisis of 2007 and 2008, regulators have moved to increase the capital adequacy of banks. Adrian Blundell-Wignall and Paul E. Atkinson stated, in a paper for the OECD, that, "it is often argued that deleveraging is "bad" if it occurs via asset contraction, because this is more damaging for the economy. Good deleveraging, on the other hand, supposedly occurs where banks raise more capital." ${ }^{63}$

\section{Tax incentives}

We uncovered two notable direct tax incentive regimes designed to drive investment capital into small public companies in our research. In the UK, the Enterprise Investment Scheme ${ }^{64}$ including the Seed Enterprise Investment Scheme (launched on 12 April 2012), creates tax breaks for investment in non-quoted companies (which may subsequently list). In South Korea, there has been a long history of aggressive government promotion of the IPO market. ${ }^{65}$ We understand that there is currently no capital gains tax for stock positions with less than $3 \%$ of total company ownership, which market participants describe as a strong inducement to retail participation.

\footnotetext{
62 Johnson, C. W. (CFA CMT) and L. Williams (2012), Market Commentary: Trends in Bond/Equities \& Trading Volume, Piper Jaffray Technical Research, 19 April.

${ }^{63}$ Blundell-Wignall, A. and P. E. Atkinson (2012), "Deleveraging, traditional versus capital markets banking and the urgent need to separate and recapitalise G-SIFI banks", OECD Journal: Financial Market Trends, Issue 1.

${ }^{64}$ HM Revenue \& Customs; Enterprise Investment Scheme found at http://www.hmrc.gov.uk/eis/index.htm.

${ }^{65}$ Kim, W. (2011), Korea's Capital Market Promotion Policies: IPOs and Other Supplementary Policy Experiences, http://ssrun.com/abstract=2194337.
} 


\section{Derivatives}

The proliferation of derivatives and its impact on cash available for investment in small capitalization companies should be better understood. ETFs, which have been available in both the United States and Europe since the 1990s, have been implicated in "choking" the IPO market. ${ }^{66}$ ETFs are generally index funds and as such, do not invest in IPOs. They also may not invest in small cap stocks, even when those stocks are included in the index that the ETF is emulating. As a result, as ETFs and other derivatives displace investment in primary securities, share prices and the availability of capital for new issues may decline.

Broadening the market

\section{Institutional allocations}

Institutions, be they pension funds or endowments, will increase (or decrease) capital to investment disciplines that they perceive to be performing (or underperforming). For example, in the United States, investment allocations to early stage venture capital have declined as ten year investment returns have lagged major stock indices. Industries, such as biotechnology, that are capital intensive and much more dependent on the IPO market both to raise capital and for exits, have been particularly hard hit. ${ }^{67}$

\section{Retail allocations/access}

Retail markets vary widely in how culture, policy and sales incentives either support or undermine the level of interest in small company stocks within the retail investor market place. There is an old cliché among Wall Street veterans that, "Stocks are sold, they're not

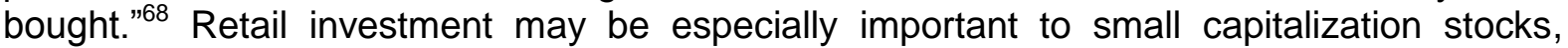
because retail investors do not generally suffer the same liquidity constraints as larger institutional investors. The emergence of low-cost online brokerage has taken the sales and marketing support of small capitalization stocks out of the stock market (especially in the United States) which has likely further crimped the flow of capital to support this market. Western Europe has generally had less direct retail participation in its new issue stock markets than either Asia or the United States. However, in the United States, since the advent of low-cost brokerage models, allocations of IPOs to retail investors have declined from what was commonly as much as $40 \%$ of an IPO in the 1990 s to less than $20 \%$ today. ${ }^{69}$

\section{Aftermarket incentives}

Adequate aftermarket incentives (whether they be tick sizes or commissions) available to market participants (institutional sales, retail sales and market makers committing capital) is the single most important determinant of the effectiveness of small IPO markets, absent

\footnotetext{
${ }^{66}$ Bradley, H. and R. E. Litan (2010), Choking the Recovery: Why new growth companies aren't going public and unrecognized risks of future market disruptions, 12 November, http://www.kauffman.org/newsroom/newreport-outlines-causes-of-market-distortions-choking-recovery.aspx.

${ }^{67}$ Source: www.nvca.org. See Venture Capital Performance at http://www.nvca.org/index.php?option=com content\&view=article\&id=344\&ltemid=103.

${ }^{68}$ SEC Concept Release on Equity Market Structure, Grant Thornton Comment Letter to the SEC dated 22 April 2010. See http://www.sec.gov/comments/s7-02-10/s70210-151.pdf.

${ }^{69}$ Conversations with equity capital markets professionals at major Wall Street investment banks.
} 
extreme forms of government intervention. ${ }^{70}$ In Exhibit 10 below, we focused our analysis only on domestic IPOs and weighted the number of small IPOs (defined as IPOs under USD 50 million in gross proceeds) for the size of their GDP to create a so-called "efficiency ratio for small domestic IPOs" for each of the top twenty-five ${ }^{71}$ IPO producing jurisdictions. We then performed a multiple regression analysis to better understand the likely drivers behind each jurisdiction's efficiency ratio. Our three dependent variables included:

1. The percentage of small stocks (sub USD 500 million in market value) with tick sizes that represented more than $1 \%$ of share price;

2. The GDP compound annual growth rate (CAGR) from 2008 to 2012; and

3. The number of public companies divided by a jurisdiction's average GDP from 2008 to 2012.

We hypothesized that higher aftermarket incentives, as defined by tick sizes greater than $1 \%$ of share value, would lead to higher small IPO production ceteris paribus (expressed as the "efficiency ratio for small domestic IPOs"). Clearly, other factors are important, such as the level of government intervention (which is why we believe that China and South Korea evidence some anomalies in their predicted rates of IPO production), tax incentives and disparities in commission structures. We also believed that core GDP growth rates were likely to prove an important driver of small IPO production, because higher economic growth rates should theoretically support larger numbers of high growth rate companies, which in turn make good IPO candidates. However, our analysis yielded a surprising result when we tested this hypothesis.

After testing for multicollinearity among the predictor variables and determining that they were not highly correlated, we ran a multiple regression using all of the top twenty-five IPO jurisdictions, which yielded a coefficient of determination (" $R^{2 \text { ") }}$ of 0.36 and an adjusted $R^{2}$ of 0.26. We determined, however, that the predicted data point for Poland was statistically inconsistent with the rest of the data. ${ }^{72}$ This seemed reasonable to us, because, at 83.4, Poland had the highest efficiency ratio of all of the jurisdictions. In fact, Poland's ratio was over two and a half times higher than the second highest jurisdiction, Canada. Removing Poland from our data set raised the $R^{2}$ to 0.72 and the adjusted $R^{2}$ to 0.67 , dramatically improving the predictive value of our model. ${ }^{73}$

\footnotetext{
${ }^{70}$ Access to Chinese markets may be reserved for and controlled by the Government which we believe has artificially limited small company access to markets in China. In Korea, the Government has a long history of incentivizing companies to go public, threatening them with loss of bank facilities if they do not go public, and incentivizing retail stock ownership. See Kim, W. (2011), Korea's Capital Market Promotion Policies: IPOs and Other Supplementary Policy Experiences.

${ }^{71}$ Our analysis excluded Chile, as we were unable to verify its tick size pricing structure.

${ }^{72}$ Since the data residuals appear to be normally distributed, $95 \%$ of the measurements should fall within two standard deviations of the mean. Therefore, we flagged any predicted values with a standardized residual greater than [2] as an outlier and subsequently removed Poland from our next iteration of the regression.

${ }^{73}$ We also tested for evidence of heteroscedasticity by plotting the residuals with the observed values of each independent variable and we determined that the regression residuals drawn appear to have the same standard deviation.
} 


\section{EXHIBIT 10}

\begin{tabular}{|c|c|c|c|c|c|c|c|}
\hline & & & & $x_{1}$ & $x_{2}$ & $x_{3}$ & $y$ \\
\hline Jurisdiction & \begin{tabular}{|c|}
$2008-2012$ \\
Average \\
GDP (USD \\
in Billions) \\
\end{tabular} & \begin{tabular}{|c|}
$2008-2012$ \\
Number of \\
Domestic \\
IPOs Deal \\
Size < \$50 \\
Million USD \\
\end{tabular} & $\begin{array}{c}\text { Total \# of } \\
\text { Public } \\
\text { Companies }\end{array}$ & $\begin{array}{c}\text { Percentage of a } \\
\text { Country's Stocks } \\
\text { with }<\$ 500 \\
\text { Million in Market } \\
\text { Value (USD) with } \\
\text { Tick Sizes }>1 \% \text { of } \\
\quad \text { Share Price } \\
\end{array}$ & \begin{tabular}{|l|} 
GDP CAGR \\
$2008-2012$ \\
\end{tabular} & \begin{tabular}{|c|} 
Total \# of \\
Public \\
Companies/ \\
2008-2012 \\
Average GDP \\
(USD in \\
Billions) \\
\end{tabular} & $\begin{array}{c}\text { Efficiency } \\
\text { Ratio for Small } \\
\text { Domestic IPOs } \\
\text { (IPOs per \$100 } \\
\text { Billion USD of } \\
\text { GDP) } \\
\end{array}$ \\
\hline Australia & $\$ 1,207.1$ & 306 & 1,492 & $90.8 \%$ & $10.0 \%$ & 1.2 & 25.4 \\
\hline Brazil & $\$ 2,063.8$ & 1 & 161 & $26.8 \%$ & $10.1 \%$ & 0.1 & 0.0 \\
\hline Canada & $\$ 1,584.7$ & 513 & 2,690 & $83.3 \%$ & $4.2 \%$ & 1.7 & 32.4 \\
\hline China & $\$ 6,202.4$ & 117 & 2,540 & $3.2 \%$ & $16.2 \%$ & 0.4 & 1.9 \\
\hline France & $\$ 2,670.7$ & 71 & 649 & $1.8 \%$ & $-2.3 \%$ & 0.2 & 2.7 \\
\hline Germany & $\$ 3,434.9$ & 17 & 695 & $9.7 \%$ & $-1.8 \%$ & 0.2 & 0.5 \\
\hline Hong Kong & $\$ 233.8$ & 58 & 1,202 & $48.8 \%$ & $4.1 \%$ & 5.1 & 24.8 \\
\hline India & $\$ 1,612.9$ & 132 & 3,059 & $18.5 \%$ & $12.3 \%$ & 1.9 & 8.2 \\
\hline Indonesia & $\$ 699.9$ & 58 & 384 & $63.1 \%$ & $15.1 \%$ & 0.5 & 8.3 \\
\hline Israel & $\$ 220.7$ & 22 & 353 & $26.5 \%$ & $5.2 \%$ & 1.6 & 10.0 \\
\hline Italy & $\$ 2,127.2$ & 16 & 214 & $1.3 \%$ & $-3.8 \%$ & 0.1 & 0.8 \\
\hline Japan & $\$ 5,444.8$ & 148 & 3,410 & $5.8 \%$ & $5.4 \%$ & 0.6 & 2.7 \\
\hline \begin{tabular}{|l|} 
Malaysia \\
\end{tabular} & $\$ 255.0$ & 73 & 831 & $46.6 \%$ & $7.4 \%$ & 3.3 & 28.6 \\
\hline \begin{tabular}{|l|} 
Mexico \\
\end{tabular} & $\$ 1,065.2$ & 0 & 79 & $11.1 \%$ & $1.5 \%$ & 0.1 & 0.0 \\
\hline Norway & $\$ 446.4$ & 8 & 208 & $0.0 \%$ & $2.4 \%$ & 0.5 & 1.8 \\
\hline \begin{tabular}{|l|} 
Poland \\
\end{tabular} & $\$ 483.0$ & 403 & 719 & $35.5 \%$ & $-2.9 \%$ & 1.5 & 83.4 \\
\hline Saudi Arabia & $\$ 507.5$ & 13 & 139 & $0.0 \%$ & $8.4 \%$ & 0.3 & 2.6 \\
\hline Singapore & $\$ 212.7$ & 62 & 614 & $86.2 \%$ & $12.6 \%$ & 2.9 & 29.1 \\
\hline South Korea & $\$ 1,009.5$ & 229 & 1,734 & $2.6 \%$ & $5.4 \%$ & 1.7 & 22.7 \\
\hline Spain & $\$ 1,449.3$ & 18 & 113 & $37.1 \%$ & $-4.2 \%$ & 0.1 & 1.2 \\
\hline Taiwan & $\$ 429.5$ & 13 & 1,677 & $0.0 \%$ & $4.3 \%$ & 3.9 & 3.0 \\
\hline \begin{tabular}{|l|} 
Thailand \\
\end{tabular} & $\$ 315.6$ & 54 & 486 & $2.9 \%$ & $8.4 \%$ & 1.5 & 17.1 \\
\hline Turkey & $\$ 726.8$ & 41 & 314 & $16.9 \%$ & $1.8 \%$ & 0.4 & 5.6 \\
\hline United Kingdom & $\$ 2,393.7$ & 80 & 1,304 & $25.7 \%$ & $-2.1 \%$ & 0.5 & 3.3 \\
\hline United States & $\$ 14,635.7$ & 58 & 3,802 & $0.0 \%$ & $2.4 \%$ & 0.3 & 0.4 \\
\hline
\end{tabular}

Excludes Chile.

Sources: Weild \& Co., Grant Thornton LLP, exchange regulations, Dealogic, Capital IQ, FactSet, the World Bank and The World Factbook 


\section{Surprising results: what drives capital formation and what does not}

Conventional wisdom holds that GDP growth rates drive capital formation. We thought so as well. Asia has notably been increasingly active in the IPO markets, while more seasoned markets, such as Europe and the United States, are generally thought to be losing ground. So, we used the GDP CAGRs of our sample of the top twenty-five IPO producing jurisdictions to perform a simple linear regression to see if GDP growth rates would predict small IPO productivity (measured as the number of small IPOs per USD 100 billion of GDP).

It turns out that GDP growth rates are a terrible predictor of small IPO productivity. The results of the linear regression yielded an $R^{2}$ of only 0.11 , excluding Poland, and 0.001 , including Poland, which led us to conclude that this variable is a very poor predictor of a jurisdiction's efficiency ratio for small domestic IPOs. ${ }^{74}$

By contrast, the amount of economic incentives in the aftermarket and the number of public companies within a jurisdiction yielded a strong predictive model. A multiple linear regression using these two variables and excluding Poland yielded an $R^{2}$ of 0.71 and an adjusted $R^{2}$ of 0.69 .

This makes sense to us: economic incentives sustain the ecosystem required to support public markets and IPOs. Cut those incentives to the point that the ecosystem cannot be sustained and performance will deteriorate-in the same way that a system of roads, bridges and tunnels would crumble without adequate investment (tolls) in its infrastructure. Additionally, a sufficient number of public companies, as measured by the number of listings within a jurisdiction and normalized (weighted) for that jurisdiction's size (as measured by GDP), is also needed to create a critical mass of investment revenue to maintain a viable capital markets ecosystem (infrastructure) capable of delivering and supporting larger numbers of IPOs.

The countries that have reputations for being the most efficient small IPO markets also offer the highest aftermarket incentives (measured by tick size as a percent of share price). These include Poland, Canada, Singapore, Australia and Hong Kong, China. By contrast, countries with less efficient IPOs have extremely low tick sizes as a percent of share prices. Examples include Mexico, France, Italy, Japan and Germany. Notably, the United States has one of the lowest small IPO efficiency ranking and one of the lowest aftermarket incentives when measured as the percent of sub USD 500 million market value stocks with tick sizes exceeding $1 \%$ of share price (see individual country tick incentive distribution patterns as a function of company market value in Exhibit 12 below).

\section{Share price}

It has been long known that "companies tend to split their stock so that the institutionally mandated minimum tick size is optimal relative to stock price." ${ }^{75}$ A corollary to this is that the distribution patterns of share prices may point to market structure idiosyncrasies: if share

\footnotetext{
${ }^{74}$ Additionally, with a set significance level of 0.05 , the calculated $P$-value was unacceptably high at 0.11 , excluding Poland, and 0.89, including Poland, leading us to accept the null hypothesis that a jurisdiction's GDP CAGR has little to no effect on its small domestic IPO efficiency ratio.

${ }^{75}$ Angel, J. J. (1997), "Tick size, share prices, and stock splits", The Journal of Finance, Volume 52, Issue 2, http://www.acsu.buffalo.edu/ keechung/MGF743/Readings/M4.pdf.
} 
prices in one country follow substantially different patterns relative to the tick size convention in other countries, it is generally the case that other policies are at work.

For example, in the United States, stocks below USD 5 per share fall under the socalled "penny stock rules." ${ }^{.76}$ In the United States, brokers are generally not allowed to solicit orders in stocks that trade under USD 5 a share and these shares do not qualify as collateral for margin. As a result, there is a strong incentive for issuers to maintain share prices above USD 5 per share, which effectively undermines the ability of issuers in the United States to improve aftermarket incentives through the use stock splits. In addition, stocks that fall below USD 1 per share in the United States are generally subject to delisting. For these reasons, we note in Exhibit 11 below that U.S. share prices skew to decidedly higher denominations, which exacerbates the relative level of economic incentive available to attract aftermarket support.

\section{EXHIBIT 11}

Stock Price Conventions Vary Widely. Lower Stock Prices in Certain Markets are Permitting Higher Economic Incentives per Share, Leading to Higher Domestic IPO Efficiency.

\begin{tabular}{|c|c|c|c|c|c|c|c|c|c|}
\hline $\begin{array}{l}\text { Stock Price per } \\
\text { Share (USD) }\end{array}$ & A. $<\$ 0.10$ & $\begin{array}{c}\text { B. } \$ 0.10 \text { to } \\
\$ 0.50\end{array}$ & $\begin{array}{l}\text { C. } \$ 0.50+ \\
\text { to } \$ 1.00\end{array}$ & $\begin{array}{l}\text { D. } \$ 1.00+ \\
\text { to } \$ 2.50\end{array}$ & $\begin{array}{l}\text { E. } \$ 2.50+ \\
\text { to } \$ 5.00\end{array}$ & $\begin{array}{l}\text { F. } \$ 5.00+ \\
\text { to } \$ 10.00\end{array}$ & $\begin{array}{l}\text { G. } \$ 10.00+ \\
\text { to } \$ 25.00\end{array}$ & H. $>\$ 25.00$ & $\begin{array}{l}\text { Grand } \\
\text { Total }\end{array}$ \\
\hline Australia & 691 & 420 & 105 & 107 & 78 & 41 & 35 & 15 & 1,492 \\
\hline Brazil & 6 & 9 & 7 & 18 & 32 & 34 & 48 & 7 & 161 \\
\hline Canada & 1,085 & 762 & 177 & 181 & 130 & 123 & 131 & 101 & 2,690 \\
\hline Chile & 21 & 25 & 14 & 15 & 11 & 10 & 11 & 6 & 113 \\
\hline China & 23 & 109 & 564 & 1,328 & 411 & 89 & 15 & 1 & 2,540 \\
\hline France & 8 & 22 & 18 & 61 & 84 & 110 & 125 & 221 & 649 \\
\hline Germany & 45 & 48 & 30 & 94 & 82 & 91 & 142 & 163 & 695 \\
\hline Hong Kong & 462 & 457 & 134 & 87 & 39 & 11 & 11 & 1 & 1,202 \\
\hline India & 563 & 1,066 & 427 & 468 & 249 & 154 & 87 & 45 & 3,059 \\
\hline Indonesia & 226 & 102 & 29 & 16 & 5 & 3 & 1 & 2 & 384 \\
\hline Israel & 53 & 58 & 29 & 57 & 43 & 45 & 39 & 29 & 353 \\
\hline Italy & 6 & 34 & 28 & 43 & 30 & 29 & 29 & 15 & 214 \\
\hline Japan & 4 & 32 & 109 & 508 & 725 & 763 & 668 & 601 & 3,410 \\
\hline Malaysia & 220 & 372 & 129 & 81 & 14 & 12 & 3 & - & 831 \\
\hline Mexico & 3 & 9 & 6 & 23 & 26 & 7 & 4 & 1 & 79 \\
\hline Norway & 15 & 35 & 21 & 39 & 30 & 24 & 30 & 14 & 208 \\
\hline Poland & 127 & 192 & 105 & 118 & 67 & 58 & 34 & 18 & 719 \\
\hline Saudi Arabia & - & - & - & 3 & 21 & 57 & 47 & 11 & 139 \\
\hline Singapore & 224 & 268 & 59 & 38 & 16 & 5 & 1 & 3 & 614 \\
\hline South Korea & 2 & 45 & 92 & 352 & 389 & 295 & 307 & 252 & 1,734 \\
\hline Spain & 3 & 11 & 10 & 18 & 17 & 21 & 15 & 17 & 112 \\
\hline Taiwan & 25 & 558 & 513 & 418 & 118 & 35 & 8 & 2 & 1,677 \\
\hline Thailand & 97 & 198 & 79 & 56 & 25 & 20 & 8 & 3 & 486 \\
\hline Turkey & 1 & 40 & 58 & 93 & 53 & 24 & 23 & 22 & 314 \\
\hline United Kingdom & 282 & 274 & 121 & 190 & 162 & 124 & 105 & 46 & 1,304 \\
\hline United States & 3 & 44 & 97 & 334 & 424 & 551 & 1,039 & 1,310 & 3,802 \\
\hline Grand Total & 4,195 & 5,190 & 2,961 & 4,746 & 3,281 & 2,736 & 2,966 & 2,906 & 28,981 \\
\hline
\end{tabular}

Primary listings and common stock/depository receipts only, excludes trusts and funds.

Sources: Weild \& Co., Grant Thornton LLP, Dealogic, Capital IQ, FactSet, the World Bank and The World Factbook

${ }^{76}$ See http://www.sec.gov/answers/penny.htm. 
The Under-Representation of Nano Cap Stocks in the U.S. is Likely the Result of

\section{Market Structure and Regulation}

Category Definitions (USD): Nano Cap = Less than $\$ 100$ million, Micro Cap $=\$ 100$ million to $\$ 500$ million, Small Cap $=\$ 500+$ million to $\$ 2$ billion, Mid Cap $=\$ 2+$ billion to $\$ 10$ billion, Large Cap $=$ Greater than $\$ 10$ billion

Number of Companies

\begin{tabular}{|c|c|c|c|c|c|c|}
\hline $\begin{array}{l}\text { Market Capitalization } \\
\text { Range }\end{array}$ & 1. Nano Cap & 2. Micro Cap & 3. Small Cap & 4. Mid Cap & 5. Large Cap & Grand Total \\
\hline Australia & 1,103 & 219 & 99 & 53 & 18 & 1,492 \\
\hline Brazil & 20 & 36 & 56 & 41 & 8 & 161 \\
\hline Canada & 2,122 & 302 & 150 & 86 & 30 & 2,690 \\
\hline Chile & 22 & 38 & 29 & 20 & 4 & 113 \\
\hline China & 64 & 1,205 & 982 & 245 & 44 & 2,540 \\
\hline France & 365 & 136 & 58 & 56 & 34 & 649 \\
\hline Germany & 417 & 142 & 61 & 52 & 23 & 695 \\
\hline Hong Kong & 437 & 364 & 214 & 136 & 51 & 1,202 \\
\hline India & 2,523 & 304 & 139 & 77 & 16 & 3,059 \\
\hline Indonesia & 158 & 105 & 76 & 37 & 8 & 384 \\
\hline Israel & 244 & 77 & 20 & 11 & 1 & 353 \\
\hline Italy & 94 & 57 & 34 & 20 & 9 & 214 \\
\hline Japan & 1,625 & 1,031 & 456 & 238 & 60 & 3,410 \\
\hline Malaysia & 582 & 162 & 53 & 24 & 10 & 831 \\
\hline Mexico & 8 & 19 & 21 & 18 & 13 & 79 \\
\hline Norway & 101 & 57 & 35 & 12 & 3 & 208 \\
\hline Poland & 617 & 70 & 20 & 11 & 1 & 719 \\
\hline Saudi Arabia & 1 & 73 & 37 & 23 & 5 & 139 \\
\hline Singapore & 369 & 161 & 52 & 20 & 12 & 614 \\
\hline South Korea & 1,028 & 493 & 116 & 78 & 19 & 1,734 \\
\hline Spain & 43 & 27 & 18 & 14 & 10 & 112 \\
\hline Taiwan & 953 & 531 & 144 & 39 & 10 & 1,677 \\
\hline Thailand & 238 & 145 & 69 & 27 & 7 & 486 \\
\hline Turkey & 168 & 86 & 40 & 16 & 4 & 314 \\
\hline United Kingdom & 732 & 246 & 161 & 125 & 40 & 1,304 \\
\hline United States & 898 & 955 & 905 & 714 & 330 & 3,802 \\
\hline Grand Total & 14,932 & 7,041 & 4,045 & 2,193 & 770 & 28,981 \\
\hline Mean (Average) & 574 & 271 & 156 & 84 & 30 & 1,115 \\
\hline
\end{tabular}


Percentage of Each Country's Market

\begin{tabular}{|c|c|c|c|c|c|c|}
\hline \begin{tabular}{|l|} 
Market Capitalization \\
Range
\end{tabular} & 1. Nano Cap & 2. Micro Cap & 3. Small Cap & 4. Mid Cap & 5. Large Cap & Grand Total \\
\hline Australia & $74 \%$ & $15 \%$ & $7 \%$ & $4 \%$ & $1 \%$ & $100 \%$ \\
\hline Brazil & $12 \%$ & $22 \%$ & $35 \%$ & $25 \%$ & $5 \%$ & $100 \%$ \\
\hline Canada & $79 \%$ & $11 \%$ & $6 \%$ & $3 \%$ & $1 \%$ & $100 \%$ \\
\hline Chile & $19 \%$ & $34 \%$ & $26 \%$ & $18 \%$ & $4 \%$ & $100 \%$ \\
\hline China & $3 \%$ & $47 \%$ & $39 \%$ & $10 \%$ & $2 \%$ & $100 \%$ \\
\hline France & $56 \%$ & $21 \%$ & $9 \%$ & $9 \%$ & $5 \%$ & $100 \%$ \\
\hline \begin{tabular}{|l|} 
Germany \\
\end{tabular} & $60 \%$ & $20 \%$ & $9 \%$ & $7 \%$ & $3 \%$ & $100 \%$ \\
\hline Hong Kong & $36 \%$ & $30 \%$ & $18 \%$ & $11 \%$ & $4 \%$ & $100 \%$ \\
\hline India & $82 \%$ & $10 \%$ & $5 \%$ & $3 \%$ & $1 \%$ & $100 \%$ \\
\hline Indonesia & $41 \%$ & $27 \%$ & $20 \%$ & $10 \%$ & $2 \%$ & $100 \%$ \\
\hline \begin{tabular}{|l|} 
Israel \\
\end{tabular} & $69 \%$ & $22 \%$ & $6 \%$ & $3 \%$ & $0 \%$ & $100 \%$ \\
\hline Italy & $44 \%$ & $27 \%$ & $16 \%$ & $9 \%$ & $4 \%$ & $100 \%$ \\
\hline Japan & $48 \%$ & $30 \%$ & $13 \%$ & $7 \%$ & $2 \%$ & $100 \%$ \\
\hline Malaysia & $70 \%$ & $19 \%$ & $6 \%$ & $3 \%$ & $1 \%$ & $100 \%$ \\
\hline Mexico & $10 \%$ & $24 \%$ & $27 \%$ & $23 \%$ & $16 \%$ & $100 \%$ \\
\hline Norway & $49 \%$ & $27 \%$ & $17 \%$ & $6 \%$ & $1 \%$ & $100 \%$ \\
\hline Poland & $86 \%$ & $10 \%$ & $3 \%$ & $2 \%$ & $0 \%$ & $100 \%$ \\
\hline Saudi Arabia & $1 \%$ & $53 \%$ & $27 \%$ & $17 \%$ & $4 \%$ & $100 \%$ \\
\hline Singapore & $60 \%$ & $26 \%$ & $8 \%$ & $3 \%$ & $2 \%$ & $100 \%$ \\
\hline South Korea & $59 \%$ & $28 \%$ & $7 \%$ & $4 \%$ & $1 \%$ & $100 \%$ \\
\hline Spain & $38 \%$ & $24 \%$ & $16 \%$ & $13 \%$ & $9 \%$ & $100 \%$ \\
\hline Taiwan & $57 \%$ & $32 \%$ & $9 \%$ & $2 \%$ & $1 \%$ & $100 \%$ \\
\hline Thailand & $49 \%$ & $30 \%$ & $14 \%$ & $6 \%$ & $1 \%$ & $100 \%$ \\
\hline Turkey & $54 \%$ & $27 \%$ & $13 \%$ & $5 \%$ & $1 \%$ & $100 \%$ \\
\hline United Kingdom & $56 \%$ & $19 \%$ & $12 \%$ & $10 \%$ & $3 \%$ & $100 \%$ \\
\hline United States & $24 \%$ & $25 \%$ & $24 \%$ & $19 \%$ & $9 \%$ & $100 \%$ \\
\hline Mean (Average) & $48 \%$ & $25 \%$ & $15 \%$ & $9 \%$ & $3 \%$ & \\
\hline
\end{tabular}




\begin{tabular}{|c|c|c|}
\hline Jurisdiction & \begin{tabular}{|c|} 
Efficiency \\
Ratio \\
(Domestic \\
IPOs per \$100 \\
Billion USD of \\
GDP) \\
\end{tabular} & $\begin{array}{l}\text { GDP CAGR } \\
2008-2012 \\
\end{array}$ \\
\hline Australia & 13.6 & $10.0 \%$ \\
\hline Brazil & 1.7 & $10.1 \%$ \\
\hline Canada & 5.2 & $4.2 \%$ \\
\hline Chile & 6.0 & $10.6 \%$ \\
\hline China & 15.2 & $16.2 \%$ \\
\hline France & 1.3 & $-2.3 \%$ \\
\hline Germany & 0.8 & $-1.8 \%$ \\
\hline Hong Kong & 29.9 & $4.1 \%$ \\
\hline India & 10.4 & $12.3 \%$ \\
\hline Indonesia & 12.7 & $15.1 \%$ \\
\hline Israel & 10.4 & $5.2 \%$ \\
\hline Italy & 0.9 & $-3.8 \%$ \\
\hline Japan & 2.6 & $5.4 \%$ \\
\hline Malaysia & 27.8 & $7.4 \%$ \\
\hline Mexico & 1.3 & $1.5 \%$ \\
\hline Norway & 3.6 & $2.4 \%$ \\
\hline Poland & 14.5 & $-2.9 \%$ \\
\hline Saudi Arabia & 8.7 & $8.4 \%$ \\
\hline Singapore & 24.4 & $12.6 \%$ \\
\hline South Korea & 22.7 & $5.4 \%$ \\
\hline Spain & 0.8 & $-4.2 \%$ \\
\hline Taiwan & 3.5 & $4.3 \%$ \\
\hline Thailand & 13.6 & $8.4 \%$ \\
\hline Turkey & 6.3 & $1.8 \%$ \\
\hline United Kingdom & 3.8 & $-2.1 \%$ \\
\hline United States & 2.6 & $2.4 \%$ \\
\hline Mean (Average) & 9.4 & $5.0 \%$ \\
\hline
\end{tabular}

Primary listings and common stock/depository receipts only, excludes trusts and funds.

Sources: Weild \& Co., Grant Thornton LLP, Dealogic, Capital IQ, FactSet, the World Bank and The World Factbook 


\section{EXHIBIT 12}

\section{Wide Range of "Tick Size as a Percentage of Share Price"}

\section{Higher Percentage Incentives May Favor Small IPOs}

Number of Companies

Australia (AUD)

Tick Size as a Percentage of Share Price

\begin{tabular}{|c|c|c|c|c|c|c|c|c|c|}
\hline $\begin{array}{l}\text { Market Capitalization } \\
\text { Range (USD) }\end{array}$ & A. $<0.1 \%$ & $\begin{array}{l}\text { B. } 0.1 \% \\
\text { to } 0.5 \%\end{array}$ & $\begin{array}{c}\text { C. } 0.5 \%+ \\
\text { to } 1 \% \\
\end{array}$ & $\begin{array}{l}\text { D. } 1 \%+ \\
\text { to } 2.5 \%\end{array}$ & $\begin{array}{c}\text { E. } 2.5 \%+ \\
\text { to } 5 \% \\
\end{array}$ & \begin{tabular}{|c} 
F. $5 \%+$ to \\
$10 \%$ \\
\end{tabular} & $\begin{array}{l}\text { G. } 10 \%+ \\
\text { to } 25 \% \\
\end{array}$ & H. $>25 \%$ & $\begin{array}{l}\text { Grand } \\
\text { Total }\end{array}$ \\
\hline 1. Nano Cap & & 11 & 18 & 490 & 344 & 108 & 79 & 53 & 1,103 \\
\hline 2. Micro Cap & 1 & 48 & 43 & 104 & 23 & & & & 219 \\
\hline 3. Small Cap & 9 & 54 & 21 & 15 & & & & & 99 \\
\hline 4. Mid Cap & 27 & 22 & 4 & & & & & & 53 \\
\hline 5. Large Cap & 12 & 6 & & & & & & & 18 \\
\hline Grand Total & 49 & 141 & 86 & 609 & 367 & 108 & 79 & 53 & 1,492 \\
\hline
\end{tabular}

Brazil (BRL)

\begin{tabular}{|c|c|c|c|c|c|c|c|c|c|}
\hline \begin{tabular}{|l|} 
Market Capitalization \\
Range (USD) \\
\end{tabular} & A. $<0.1 \%$ & $\begin{array}{l}\text { B. } 0.1 \% \\
\text { to } 0.5 \% \\
\end{array}$ & \begin{tabular}{|c|} 
C. $0.5 \%+$ \\
to $1 \%$ \\
\end{tabular} & $\begin{array}{l}\text { D. } 1 \%+ \\
\text { to } 2.5 \%\end{array}$ & \begin{tabular}{|c|} 
E. $2.5 \%+$ \\
to $5 \%$ \\
\end{tabular} & \begin{tabular}{|c|} 
F. $5 \%+$ to \\
$10 \%$ \\
\end{tabular} & \begin{tabular}{|l|} 
G. $10 \%+$ \\
to $25 \%$ \\
\end{tabular} & H. $>\mathbf{2 5 \%}$ & $\begin{array}{l}\text { Grand } \\
\text { Total }\end{array}$ \\
\hline 1. Nano Cap & 3 & 5 & 2 & 3 & 2 & 1 & 3 & 1 & 20 \\
\hline 2. Micro Cap & 9 & 20 & 2 & 4 & & & 1 & & 36 \\
\hline 3. Small Cap & 37 & 18 & 1 & & & & & & 56 \\
\hline 4. Mid Cap & 35 & 5 & 1 & & & & & & 41 \\
\hline 5. Large Cap & 8 & & & & & & & & 8 \\
\hline Grand Total & 92 & 48 & 6 & 7 & 2 & 1 & 4 & 1 & 161 \\
\hline
\end{tabular}

Canada (CAD)

Tick Size as a Percentage of Share Price

\begin{tabular}{|c|c|c|c|c|c|c|c|c|c|}
\hline $\begin{array}{l}\text { Market Capitalization } \\
\text { Range (USD) }\end{array}$ & A. $<0.1 \%$ & $\begin{array}{l}\text { B. } 0.1 \% \\
\text { to } 0.5 \%\end{array}$ & \begin{tabular}{|c|} 
C. $0.5 \%+$ \\
to $1 \%$ \\
\end{tabular} & $\begin{array}{l}\text { D. } 1 \%+ \\
\text { to } 2.5 \%\end{array}$ & $\begin{array}{c}\text { E. } 2.5 \%+ \\
\text { to } 5 \% \\
\end{array}$ & \begin{tabular}{|c|} 
F. $5 \%+$ to \\
$10 \%$
\end{tabular} & $\begin{array}{l}\text { G. } 10 \%+ \\
\text { to } 25 \%\end{array}$ & H. $>\mathbf{2 5 \%}$ & $\begin{array}{c}\text { Grand } \\
\text { Total }\end{array}$ \\
\hline 1. Nano Cap & 5 & 83 & 72 & 535 & 399 & 461 & 397 & 170 & 2,122 \\
\hline 2. Micro Cap & 59 & 134 & 53 & 53 & 3 & & & & 302 \\
\hline 3. Small Cap & 69 & 74 & 6 & 1 & & & & & 150 \\
\hline 4. Mid Cap & 73 & 13 & & & & & & & 86 \\
\hline 5. Large Cap & 30 & & & & & & & & 30 \\
\hline Grand Total & 236 & 304 & 131 & 589 & 402 & 461 & 397 & 170 & 2,690 \\
\hline
\end{tabular}

China (CNY)

Tick Size as a Percentage of Share Price

\begin{tabular}{|c|c|c|c|c|c|c|c|c|c|}
\hline $\begin{array}{l}\text { Market Capitalization } \\
\text { Range (USD) }\end{array}$ & A. $<0.1 \%$ & $\begin{array}{l}\text { B. } 0.1 \% \\
\text { to } 0.5 \% \\
\end{array}$ & $\begin{array}{c}\text { C. } 0.5 \%+ \\
\text { to } 1 \% \\
\end{array}$ & $\begin{array}{l}\text { D. } 1 \%+ \\
\text { to } 2.5 \% \\
\end{array}$ & $\begin{array}{c}\text { E. } 2.5 \%+ \\
\text { to } 5 \% \\
\end{array}$ & \begin{tabular}{|c|} 
F. $5 \%+$ to \\
$10 \%$ \\
\end{tabular} & $\begin{array}{l}\text { G. } 10 \%+ \\
\text { to } 25 \%\end{array}$ & H. $>25 \%$ & $\begin{array}{c}\text { Grand } \\
\text { Total } \\
\end{array}$ \\
\hline 1. Nano Cap & & 14 & 10 & 36 & 4 & & & & 64 \\
\hline 2. Micro Cap & 459 & 744 & 2 & & & & & & 1,205 \\
\hline 3. Small Cap & 507 & 473 & 2 & & & & & & 982 \\
\hline 4. Mid Cap & 137 & 108 & & & & & & & 245 \\
\hline 5. Large Cap & 26 & 18 & & & & & & & 44 \\
\hline Grand Total & 1,129 & 1,357 & 14 & 36 & 4 & & & & 2,540 \\
\hline
\end{tabular}


France (EUR)

Tick Size as a Percentage of Share Price

\begin{tabular}{|c|c|c|c|c|c|c|c|c|c|}
\hline \begin{tabular}{|l|} 
Market Capitalization \\
Range (USD) \\
\end{tabular} & A. $<0.1 \%$ & $\begin{array}{l}\text { B. } 0.1 \% \\
\text { to } 0.5 \% \\
\end{array}$ & \begin{tabular}{|c|} 
C. $0.5 \%+$ \\
to $1 \%$ \\
\end{tabular} & $\begin{array}{l}\text { D. } 1 \%+ \\
\text { to } 2.5 \%\end{array}$ & \begin{tabular}{|c|} 
E. $2.5 \%+$ \\
to $5 \%$ \\
\end{tabular} & \begin{tabular}{|c|} 
F. $5 \%+$ to \\
$10 \%$ \\
\end{tabular} & \begin{tabular}{|l|} 
G. $10 \%+$ \\
to $25 \%$ \\
\end{tabular} & H. $>25 \%$ & $\begin{array}{c}\text { Grand } \\
\text { Total } \\
\end{array}$ \\
\hline 1. Nano Cap & 306 & 43 & 7 & 6 & 3 & & & & 365 \\
\hline 2. Micro Cap & 133 & 3 & & & & & & & 136 \\
\hline 3. Small Cap & 58 & & & & & & & & 58 \\
\hline 4. Mid Cap & 56 & & & & & & & & 56 \\
\hline 5. Large Cap & 34 & & & & & & & & 34 \\
\hline Grand Total & 587 & 46 & 7 & 6 & 3 & & & & 649 \\
\hline
\end{tabular}

Germany (EUR)

Tick Size as a Percentage of Share Price

\begin{tabular}{|c|c|c|c|c|c|c|c|c|c|}
\hline $\begin{array}{l}\text { Market Capitalization } \\
\text { Range (USD) }\end{array}$ & A. $<0.1 \%$ & $\begin{array}{l}\text { B. } 0.1 \% \\
\text { to } 0.5 \%\end{array}$ & \begin{tabular}{|c|} 
C. $0.5 \%+$ \\
to $1 \%$
\end{tabular} & $\begin{array}{l}\text { D. } 1 \%+ \\
\text { to } 2.5 \%\end{array}$ & $\begin{array}{c}\text { E. } 2.5 \%+ \\
\text { to } 5 \%\end{array}$ & $\begin{array}{c}\text { F. } 5 \%+\text { to } \\
10 \%\end{array}$ & $\begin{array}{l}\text { G. } 10 \%+ \\
\text { to } 25 \%\end{array}$ & H. $>25 \%$ & $\begin{array}{l}\text { Grand } \\
\text { Total }\end{array}$ \\
\hline 1. Nano Cap & 273 & 75 & 15 & 23 & 17 & 9 & 4 & 1 & 417 \\
\hline 2. Micro Cap & 141 & 1 & & & & & & & 142 \\
\hline 3. Small Cap & 60 & 1 & & & & & & & 61 \\
\hline 4. Mid Cap & 52 & & & & & & & & 52 \\
\hline 5. Large Cap & 23 & & & & & & & & 23 \\
\hline Grand Total & 549 & 77 & 15 & 23 & 17 & 9 & 4 & 1 & 695 \\
\hline
\end{tabular}

Hong Kong (HKD)

Market Capitalization

Range (USD)

1. Nano Cap

2. Micro Cap

3. Small Cap

4. Mid Cap

5. Large Cap

Grand Total

Tick Size as a Percentage of Share Price

\begin{tabular}{|c|c|c|c|c|c|c|c|c|c|}
\hline India (INR) & & & Tick & Gize as a $\mathrm{P}$ & ercentage & of Share F & Price & & \\
\hline $\begin{array}{l}\text { Market Capitalization } \\
\text { Range (USD) }\end{array}$ & A. $<0.1 \%$ & $\begin{array}{l}\text { B. } 0.1 \% \\
\text { to } 0.5 \%\end{array}$ & $\begin{array}{c}\text { C. } 0.5 \%+ \\
\text { to } 1 \%\end{array}$ & $\begin{array}{l}\text { D. } 1 \%+ \\
\text { to } 2.5 \%\end{array}$ & $\begin{array}{c}\text { E. } 2.5 \%+ \\
\text { to } 5 \%\end{array}$ & $\mid \begin{array}{c}\text { F. } 5 \%+\text { to } \\
10 \%\end{array}$ & $\begin{array}{l}\text { G. } 10 \%+ \\
\text { to } 25 \%\end{array}$ & H. $>\mathbf{2 5} \%$ & $\begin{array}{l}\text { Grand } \\
\text { Total }\end{array}$ \\
\hline 1. Nano Cap & 603 & 1,004 & 396 & 308 & 109 & 51 & 38 & 14 & 2,523 \\
\hline 2. Micro Cap & 239 & 57 & 6 & 1 & 1 & & & & 304 \\
\hline 3. Small Cap & 127 & 12 & & & & & & & 139 \\
\hline 4. Mid Cap & 74 & 3 & & & & & & & 77 \\
\hline 5. Large Cap & 16 & & & & & & & & 16 \\
\hline Grand Total & 1,059 & 1,076 & 402 & 309 & 110 & 51 & 38 & 14 & 3,059 \\
\hline
\end{tabular}

Indonesia (IDR)

Tick Size as a Percentage of Share Price

\begin{tabular}{|c|c|c|c|c|c|c|c|c|c|}
\hline $\begin{array}{l}\text { Market Capitalization } \\
\text { Range (USD) }\end{array}$ & A. $<0.1 \%$ & $\begin{array}{l}\text { B. } 0.1 \% \\
\text { to } 0.5 \%\end{array}$ & \begin{tabular}{|c|} 
C. $0.5 \%+$ \\
to $1 \%$ \\
\end{tabular} & $\begin{array}{l}\text { D. } 1 \%+ \\
\text { to } 2.5 \%\end{array}$ & $\begin{array}{c}\text { E. } 2.5 \%+ \\
\text { to } 5 \% \\
\end{array}$ & \begin{tabular}{|c|} 
F. $5 \%+$ to \\
$10 \%$ \\
\end{tabular} & $\begin{array}{l}\text { G. } 10 \%+ \\
\text { to } 25 \%\end{array}$ & H. $>\mathbf{2 5} \%$ & $\begin{array}{c}\text { Grand } \\
\text { Total } \\
\end{array}$ \\
\hline 1. Nano Cap & 1 & 3 & 50 & 104 & & & & & 158 \\
\hline 2. Micro Cap & & 2 & 41 & 62 & & & & & 105 \\
\hline 3. Small Cap & 2 & 2 & 45 & 27 & & & & & 76 \\
\hline 4. Mid Cap & 1 & 9 & 25 & 2 & & & & & 37 \\
\hline 5. Large Cap & 2 & 4 & 2 & & & & & & 8 \\
\hline Grand Total & 6 & 20 & 163 & 195 & & & & & 384 \\
\hline
\end{tabular}


Israel (ILS)

Tick Size as a Percentage of Share Price

\begin{tabular}{|c|c|c|c|c|c|c|c|c|c|}
\hline \begin{tabular}{|l|} 
Market Capitalization \\
Range (USD) \\
\end{tabular} & A. $<0.1 \%$ & $\begin{array}{l}\text { B. } 0.1 \% \\
\text { to } 0.5 \% \\
\end{array}$ & \begin{tabular}{|c|} 
C. $0.5 \%+$ \\
to $1 \%$ \\
\end{tabular} & $\begin{array}{l}\text { D. } 1 \%+ \\
\text { to } 2.5 \% \\
\end{array}$ & \begin{tabular}{|c|} 
E. $2.5 \%+$ \\
to $5 \%$ \\
\end{tabular} & \begin{tabular}{|c|} 
F. $5 \%+$ to \\
$10 \%$ \\
\end{tabular} & \begin{tabular}{|l|} 
G. $10 \%+$ \\
to $25 \%$ \\
\end{tabular} & H. $>\mathbf{2 5 \%}$ & $\begin{array}{l}\text { Grand } \\
\text { Total }\end{array}$ \\
\hline 1. Nano Cap & 56 & 80 & 26 & 31 & 23 & 18 & 5 & 5 & 244 \\
\hline 2. Micro Cap & 68 & 6 & & & 1 & 1 & 1 & & 77 \\
\hline 3. Small Cap & 16 & 2 & 1 & & 1 & & & & 20 \\
\hline 4. Mid Cap & 8 & 2 & & 1 & & & & & 11 \\
\hline 5. Large Cap & 1 & & & & & & & & 1 \\
\hline Grand Total & 149 & 90 & 27 & 32 & 25 & 19 & 6 & 5 & 353 \\
\hline
\end{tabular}

Italy (EUR)

\begin{tabular}{|c|c|c|c|c|c|c|c|c|c|}
\hline taly & & & Tick & jize as a $\mathrm{F}$ & ercentage & of Share $\mathrm{P}$ & Price & & \\
\hline $\begin{array}{l}\text { Market Capitalization } \\
\text { Range (USD) }\end{array}$ & A. $<0.1 \%$ & $\begin{array}{l}\text { B. } 0.1 \% \\
\text { to } 0.5 \%\end{array}$ & $\begin{array}{c}\text { C. } 0.5 \%+ \\
\text { to } 1 \%\end{array}$ & $\begin{array}{l}\text { D. } 1 \%+ \\
\text { to } 2.5 \%\end{array}$ & $\begin{array}{c}\text { E. } 2.5 \%+ \\
\text { to } 5 \%\end{array}$ & \begin{tabular}{|c|} 
F. $5 \%+$ to \\
$10 \%$
\end{tabular} & $\begin{array}{l}\text { G. } 10 \%+ \\
\text { to } 25 \%\end{array}$ & H. $>25 \%$ & $\begin{array}{l}\text { Grand } \\
\text { Total }\end{array}$ \\
\hline 1. Nano Cap & 69 & 23 & & 1 & 1 & & & & 94 \\
\hline 2. Micro Cap & 49 & 8 & & & & & & & 57 \\
\hline 3. Small Cap & 30 & 4 & & & & & & & 34 \\
\hline 4. Mid Cap & 20 & & & & & & & & 20 \\
\hline 5. Large Cap & 9 & & & & & & & & 9 \\
\hline Grand Total & 177 & 35 & & 1 & 1 & & & & 214 \\
\hline
\end{tabular}

Japan (JPY)

Tick Size as a Percentage of Share Price

\begin{tabular}{|c|c|c|c|c|c|c|c|c|c|}
\hline \begin{tabular}{|l} 
Market Capitalization \\
Range (USD) \\
\end{tabular} & A. $<0.1 \%$ & $\begin{array}{l}\text { B. } 0.1 \% \\
\text { to } 0.5 \% \\
\end{array}$ & \begin{tabular}{|c|} 
C. $0.5 \%+$ \\
to $1 \%$ \\
\end{tabular} & $\begin{array}{l}\text { D. } 1 \%+ \\
\text { to } 2.5 \%\end{array}$ & \begin{tabular}{|c|} 
E. $2.5 \%+$ \\
to $5 \%$ \\
\end{tabular} & \begin{tabular}{|c|} 
F. $5 \%+$ to \\
$10 \%$ \\
\end{tabular} & \begin{tabular}{|l|} 
G. $10 \%+$ \\
to $25 \%$ \\
\end{tabular} & H. $>\mathbf{2 5 \%}$ & $\begin{array}{c}\text { Grand } \\
\text { Total } \\
\end{array}$ \\
\hline 1. Nano Cap & 175 & 1,035 & 282 & 115 & 10 & 4 & 3 & 1 & 1,625 \\
\hline 2. Micro Cap & 220 & 678 & 112 & 18 & 3 & & & & 1,031 \\
\hline 3. Small Cap & 131 & 307 & 16 & 2 & & & & & 456 \\
\hline 4. Mid Cap & 68 & 160 & 10 & & & & & & 238 \\
\hline 5. Large Cap & 14 & 45 & 1 & & & & & & 60 \\
\hline Grand Total & 608 & 2,225 & 421 & 135 & 13 & 4 & 3 & 1 & 3,410 \\
\hline
\end{tabular}

Malaysia (MYR)

Tick Size as a Percentage of Share Price

\begin{tabular}{|l|r|r|r|r|r|r|r|r|r|}
\hline $\begin{array}{l}\text { Market Capitalization } \\
\text { Range (USD) }\end{array}$ & A. $<\mathbf{0 . 1 \%}$ & $\begin{array}{r}\text { B. } \mathbf{0 . 1 \%} \\
\text { to } \mathbf{0 . 5 \%}\end{array}$ & $\begin{array}{c}\text { C. } \mathbf{0 . 5 \% +} \\
\text { to } \mathbf{1 \%}\end{array}$ & $\begin{array}{c}\text { D. } \mathbf{1 \% +} \\
\text { to } \mathbf{2 . 5 \%}\end{array}$ & $\begin{array}{c}\text { E. 2.5\%+ } \\
\text { to } \mathbf{5 \%}\end{array}$ & $\begin{array}{c}\text { F. 5\%+ to } \\
\mathbf{1 0 \%}\end{array}$ & $\begin{array}{c}\text { G. 10\%+ } \\
\text { to 25\% }\end{array}$ & H. >25\% & $\begin{array}{c}\text { Grand } \\
\text { Total }\end{array}$ \\
\hline 1. Nano Cap & & 25 & 223 & 201 & 97 & 34 & 2 & & $\mathbf{5 8 2}$ \\
\hline 2. Micro Cap & 1 & 72 & 76 & 13 & & & & & $\mathbf{1 6 2}$ \\
\hline 3. Small Cap & 2 & 46 & 5 & & & & & & $\mathbf{5 3}$ \\
\hline 4. Mid Cap & 5 & 18 & 1 & & & & & & $\mathbf{2 4}$ \\
\hline 5. Large Cap & 1 & 9 & & & & & & & $\mathbf{1 0}$ \\
\hline Grand Total & $\mathbf{9}$ & $\mathbf{1 7 0}$ & $\mathbf{3 0 5}$ & $\mathbf{2 1 4}$ & $\mathbf{9 7}$ & $\mathbf{3 4}$ & $\mathbf{2}$ & & $\mathbf{8 3 1}$ \\
\hline
\end{tabular}

Mexico (MXN)

Tick Size as a Percentage of Share Price

\begin{tabular}{|c|c|c|c|c|c|c|c|c|c|}
\hline $\begin{array}{l}\text { Market Capitalization } \\
\text { Range (USD) } \\
\end{array}$ & A. $<0.1 \%$ & $\begin{array}{l}\text { B. } 0.1 \% \\
\text { to } 0.5 \% \\
\end{array}$ & $\begin{array}{c}\text { C. } 0.5 \%+ \\
\text { to } 1 \% \\
\end{array}$ & $\begin{array}{l}\text { D. } 1 \%+ \\
\text { to } 2.5 \% \\
\end{array}$ & $\begin{array}{c}\text { E. } 2.5 \%+ \\
\text { to } 5 \% \\
\end{array}$ & \begin{tabular}{|c|} 
F. $5 \%+$ to \\
$10 \%$ \\
\end{tabular} & $\begin{array}{l}\text { G. } 10 \%+ \\
\text { to } 25 \%\end{array}$ & H. $>25 \%$ & $\begin{array}{l}\text { Grand } \\
\text { Total }\end{array}$ \\
\hline 1. Nano Cap & 1 & 4 & & 2 & 1 & & & & 8 \\
\hline 2. Micro Cap & 10 & 8 & 1 & & & & & & 19 \\
\hline 3. Small Cap & 20 & 1 & & & & & & & 21 \\
\hline 4. Mid Cap & 18 & & & & & & & & 18 \\
\hline 5. Large Cap & 13 & & & & & & & & 13 \\
\hline Grand Total & 62 & 13 & 1 & 2 & 1 & & & & 79 \\
\hline
\end{tabular}


Norway (NOK)

\begin{tabular}{|c|c|c|c|c|c|c|c|c|c|}
\hline \begin{tabular}{|l|} 
Market Capitalization \\
Range (USD) \\
\end{tabular} & A. $<0.1 \%$ & $\begin{array}{l}\text { B. } 0.1 \% \\
\text { to } 0.5 \% \\
\end{array}$ & \begin{tabular}{|c|} 
C. $0.5 \%+$ \\
to $1 \%$ \\
\end{tabular} & $\begin{array}{l}\text { D. } 1 \%+ \\
\text { to } 2.5 \% \\
\end{array}$ & \begin{tabular}{|c|} 
E. $2.5 \%+$ \\
to $5 \%$ \\
\end{tabular} & \begin{tabular}{|c|} 
F. $5 \%+$ to \\
$10 \%$ \\
\end{tabular} & \begin{tabular}{|l|} 
G. $10 \%+$ \\
to $25 \%$ \\
\end{tabular} & H. $>\mathbf{2 5 \%}$ & $\begin{array}{l}\text { Grand } \\
\text { Total }\end{array}$ \\
\hline 1. Nano Cap & 96 & 3 & 2 & & & & & & 101 \\
\hline 2. Micro Cap & 57 & & & & & & & & 57 \\
\hline 3. Small Cap & 35 & & & & & & & & 35 \\
\hline 4. Mid Cap & 12 & & & & & & & & 12 \\
\hline 5. Large Cap & 3 & & & & & & & & 3 \\
\hline Grand Total & 203 & 3 & 2 & & & & & & 208 \\
\hline
\end{tabular}

Poland (PLN)

Market Capitalization

Range (USD)

1. Nano Cap

2. Micro Cap

3. Small Cap

4. Mid Cap

5. Large Cap

Grand Total

Tick Size as a Percentage of Share Price

\begin{tabular}{|r|r|}
\hline A. $<\mathbf{0 . 1 \%}$ & \\
\hline 85 & \\
\hline 49 & \\
\hline 16 & \\
\hline 8 & \\
\hline 158 & \\
\hline
\end{tabular}

\section{B. $0.1 \%$ C. $0.5 \%+$} D. $1 \%+$

\begin{tabular}{|r|r|}
\hline $\begin{array}{r}\text { E. 2.5\%+ } \\
\text { to } 5 \%\end{array}$ & F \\
\hline 53 & \\
\hline 1 & \\
\hline & \\
\hline & \\
\hline 54 & \\
\hline
\end{tabular}

\begin{tabular}{|r|r|r|r|}
\hline $\begin{array}{c}\text { F. 5\%+to Share Price } \\
10 \%\end{array}$ & $\begin{array}{c}\text { G. } \mathbf{1 0 \% +} \\
\text { to } \mathbf{2 5 \%}\end{array}$ & H. $>\mathbf{2 5 \%}$ & $\begin{array}{c}\text { Grand } \\
\text { Total }\end{array}$ \\
\hline 37 & 37 & 22 & 617 \\
\hline & 1 & & 70 \\
\hline & & & 20 \\
\hline 37 & & & 11 \\
\hline & & & 1 \\
\hline
\end{tabular}

Saudi Arabia (SAR)

\begin{tabular}{|l|}
\hline $\begin{array}{l}\text { Market Capitalization } \\
\text { Range (USD) }\end{array}$ \\
\hline 1. Nano Cap \\
\hline 2. Micro Cap \\
\hline 3. Small Cap \\
\hline 4. Mid Cap \\
\hline 5. Large Cap \\
\hline Grand Total \\
\hline
\end{tabular}

Tick Size as a Percentage of Share Price

\begin{tabular}{|c|c|c|c|c|c|c|c|c|}
\hline A. $<0.1 \%$ & $\begin{array}{l}\text { B. } 0.1 \% \\
\text { to } 0.5 \%\end{array}$ & $\begin{array}{c}\text { C. } 0.5 \%+ \\
\text { to } 1 \%\end{array}$ & $\begin{array}{l}\text { D. } 1 \%+ \\
\text { to } 2.5 \%\end{array}$ & $\begin{array}{c}\text { E. } 2.5 \%+ \\
\text { to } 5 \%\end{array}$ & $\begin{array}{c}\text { F. } 5 \%+\text { to } \\
10 \%\end{array}$ & $\begin{array}{l}\text { G. } 10 \%+ \\
\text { to } 25 \%\end{array}$ & H. $>25 \%$ & $\begin{array}{l}\text { Grand } \\
\text { Total }\end{array}$ \\
\hline & 1 & & & & & & & 1 \\
\hline & 73 & & & & & & & 73 \\
\hline & 37 & & & & & & & 37 \\
\hline & 20 & 3 & & & & & & 23 \\
\hline & 5 & & & & & & & 5 \\
\hline & 136 & 3 & & & & & & 139 \\
\hline
\end{tabular}

Singapore (SGD)

Tick Size as a Percentage of Share Price

\begin{tabular}{|l|r|r|r|r|r|r|r|r|r|}
\hline $\begin{array}{l}\text { Market Capitalization } \\
\text { Range (USD) }\end{array}$ & A. $<\mathbf{0 . 1 \%}$ & $\begin{array}{r}\text { B. } \mathbf{0 . 1 \%} \\
\text { to } \mathbf{0 . 5 \%}\end{array}$ & $\begin{array}{c}\text { C. } \mathbf{0 . 5 \% +} \\
\text { to } \mathbf{1 \%}\end{array}$ & $\begin{array}{r}\text { D. 1\%+ } \\
\text { to } \mathbf{2 . 5 \%}\end{array}$ & $\begin{array}{c}\text { E. 2.5\%+ } \\
\text { to } \mathbf{5 \%}\end{array}$ & $\begin{array}{c}\text { F. 5\%+ to } \\
\mathbf{1 0 \%}\end{array}$ & $\begin{array}{c}\text { G. 10\%+ } \\
\text { to 25\% }\end{array}$ & H. >25\% & $\begin{array}{r}\text { Grand } \\
\text { Total }\end{array}$ \\
\hline 1. Nano Cap & & 1 & 9 & 80 & 109 & 83 & 63 & 24 & $\mathbf{3 6 9}$ \\
\hline 2. Micro Cap & & 5 & 58 & 66 & 15 & 8 & 7 & 2 & $\mathbf{1 6 1}$ \\
\hline 3. Small Cap & & 4 & 38 & 8 & 2 & & & & 52 \\
\hline 4. Mid Cap & & 11 & 9 & & & & & & 20 \\
\hline 5. Large Cap & & 4 & 8 & & & & & & 12 \\
\hline Grand Total & & $\mathbf{2 5}$ & $\mathbf{1 2 2}$ & $\mathbf{1 5 4}$ & $\mathbf{1 2 6}$ & $\mathbf{9 1}$ & $\mathbf{7 0}$ & $\mathbf{2 6}$ & $\mathbf{6 1 4}$ \\
\hline
\end{tabular}

South Korea (KRW)

Market Capitalization

Range (USD)

1. Nano Cap

2. Micro Cap

3. Small Cap

4. Mid Cap

5. Large Cap

Grand Total
Tick Size as a Percentage of Share Price

\begin{tabular}{|c|c|c|c|c|c|c|c|c|}
\hline A. $<0.1 \%$ & $\begin{array}{l}\text { B. } 0.1 \% \\
\text { to } 0.5 \%\end{array}$ & $\begin{array}{c}\text { C. } 0.5 \%+ \\
\text { to } 1 \%\end{array}$ & $\begin{array}{l}\text { D. } 1 \%+ \\
\text { to } 2.5 \%\end{array}$ & $\begin{array}{c}\text { E. } 2.5 \%+ \\
\text { to } 5 \%\end{array}$ & \begin{tabular}{|c} 
F. $5 \%+$ to \\
$10 \%$ \\
\end{tabular} & $\begin{array}{l}\text { G. } 10 \%+ \\
\text { to } 25 \%\end{array}$ & H. $>25 \%$ & $\begin{array}{c}\text { Grand } \\
\text { Total }\end{array}$ \\
\hline & 911 & 78 & 34 & 3 & & & 2 & 1,028 \\
\hline & 487 & 6 & & & & & & 493 \\
\hline 4 & 112 & & & & & & & 116 \\
\hline 3 & 75 & & & & & & & 78 \\
\hline 1 & 18 & & & & & & & 19 \\
\hline 8 & 1,603 & 84 & 34 & 3 & & & 2 & 1,734 \\
\hline
\end{tabular}


Spain (EUR)

\begin{tabular}{|l|}
\hline Market Capitalization \\
Range (USD) \\
\hline 1. Nano Cap \\
\hline 2. Micro Cap \\
\hline 3. Small Cap \\
\hline 4. Mid Cap \\
\hline 5. Large Cap \\
\hline Grand Total \\
\hline
\end{tabular}

Tick Size as a Percentage of Share Price

\begin{tabular}{|r|r|r|r|r|r|r|r|r|} 
A. $<\mathbf{0 . 1 \%}$ & $\begin{array}{r}\text { B. } \mathbf{0 . 1 \%} \\
\text { to } \mathbf{0 . 5 \%}\end{array}$ & $\begin{array}{c}\text { C. } \mathbf{0 . 5 \% +} \\
\text { to } \mathbf{1 \%}\end{array}$ & $\begin{array}{c}\text { D. } \mathbf{1 \% +} \\
\text { to } \mathbf{2 . 5 \%}\end{array}$ & $\begin{array}{c}\text { E. 2.5\%+ } \\
\text { to } \mathbf{5 \%}\end{array}$ & $\begin{array}{c}\text { F. 5\%+ to } \\
\mathbf{1 0 \%}\end{array}$ & $\begin{array}{c}\text { G. 10\%+ } \\
\text { to } \mathbf{2 5 \%}\end{array}$ & H. $\mathbf{2 5 \%}$ & $\begin{array}{c}\text { Grand } \\
\text { Total }\end{array}$ \\
\hline 1 & 12 & 8 & 11 & 7 & 2 & 1 & 1 & $\mathbf{4 3}$ \\
\hline 6 & 11 & 6 & 2 & 2 & & & & $\mathbf{2 7}$ \\
\hline 2 & 15 & 1 & & & & & & $\mathbf{1 8}$ \\
\hline 10 & 4 & & & & & & & 14 \\
\hline 9 & 1 & & & & & & & 10 \\
\hline 28 & 43 & 15 & 13 & 9 & 2 & 1 & 1 & 112 \\
\hline
\end{tabular}

Taiwan (TWD)

\begin{tabular}{|c|c|c|c|c|c|c|c|c|c|}
\hline $\begin{array}{l}\text { Market Capitalization } \\
\text { Range (USD) }\end{array}$ & A. $<0.1 \%$ & $\begin{array}{l}\text { B. } 0.1 \% \\
\text { to } 0.5 \% \\
\end{array}$ & \begin{tabular}{|c|} 
C. $0.5 \%+$ \\
to $1 \%$ \\
\end{tabular} & $\begin{array}{l}\text { D. } 1 \%+ \\
\text { to } 2.5 \%\end{array}$ & \begin{tabular}{|c|} 
E. $2.5 \%+$ \\
to $5 \%$ \\
\end{tabular} & \begin{tabular}{|c|} 
F. $5 \%+$ to \\
$10 \%$ \\
\end{tabular} & \begin{tabular}{|l|} 
G. $10 \%+$ \\
to $25 \%$ \\
\end{tabular} & H. $>\mathbf{2 5 \%}$ & $\begin{array}{c}\text { Grand } \\
\text { Total } \\
\end{array}$ \\
\hline 1. Nano Cap & & 948 & 5 & & & & & & 953 \\
\hline 2. Micro Cap & & 530 & 1 & & & & & & 531 \\
\hline 3. Small Cap & & 144 & & & & & & & 144 \\
\hline 4. Mid Cap & & 39 & & & & & & & 39 \\
\hline 5. Large Cap & & 10 & & & & & & & 10 \\
\hline Grand Total & & 1,671 & 6 & & & & & & 1,677 \\
\hline
\end{tabular}

Thailand (THB)

\begin{tabular}{|c|c|c|c|c|c|c|c|c|c|}
\hline $\begin{array}{l}\text { Market Capitalization } \\
\text { Range (USD) }\end{array}$ & A. $<0.1 \%$ & $\begin{array}{l}\text { B. } 0.1 \% \\
\text { to } 0.5 \%\end{array}$ & $\begin{array}{c}\text { C. } 0.5 \%+ \\
\text { to } 1 \% \\
\end{array}$ & $\begin{array}{l}\text { D. } 1 \%+ \\
\text { to } 2.5 \%\end{array}$ & $\begin{array}{c}\text { E. } 2.5 \%+ \\
\text { to } 5 \%\end{array}$ & \begin{tabular}{|c|} 
F. $5 \%+$ to \\
$10 \%$ \\
\end{tabular} & $\begin{array}{l}\text { G. } 10 \%+ \\
\text { to } 25 \%\end{array}$ & H. $>\mathbf{2 5 \%}$ & $\begin{array}{c}\text { Grand } \\
\text { Total }\end{array}$ \\
\hline 1. Nano Cap & & 21 & 209 & 6 & 1 & 1 & & & 238 \\
\hline 2. Micro Cap & & 16 & 126 & 1 & 1 & 1 & & & 145 \\
\hline 3. Small Cap & & 12 & 55 & 1 & & 1 & & & 69 \\
\hline 4. Mid Cap & & 1 & 26 & & & & & & 27 \\
\hline 5. Large Cap & & & 7 & & & & & & 7 \\
\hline Grand Total & & 50 & 423 & 8 & 2 & 3 & & & 486 \\
\hline
\end{tabular}

Turkey (TRY)

Tick Size as a Percentage of Share Price

\begin{tabular}{|c|c|c|c|c|c|c|c|c|c|}
\hline $\begin{array}{l}\text { Market Capitalization } \\
\text { Range (USD) } \\
\end{array}$ & A. $<0.1 \%$ & $\begin{array}{l}\text { B. } 0.1 \% \\
\text { to } 0.5 \%\end{array}$ & $\begin{array}{c}\text { C. } 0.5 \%+ \\
\text { to } 1 \% \\
\end{array}$ & $\begin{array}{l}\text { D. } 1 \%+ \\
\text { to } 2.5 \%\end{array}$ & $\begin{array}{c}\text { E. } 2.5 \%+ \\
\text { to } 5 \% \\
\end{array}$ & \begin{tabular}{|c|} 
F. $5 \%+$ to \\
$10 \%$ \\
\end{tabular} & $\begin{array}{l}\text { G. } 10 \%+ \\
\text { to } 25 \% \\
\end{array}$ & H. $>25 \%$ & $\begin{array}{c}\text { Grand } \\
\text { Total }\end{array}$ \\
\hline 1. Nano Cap & & 81 & 47 & 34 & 5 & 1 & & & 168 \\
\hline 2. Micro Cap & & 72 & 11 & 3 & & & & & 86 \\
\hline 3. Small Cap & & 36 & 3 & 1 & & & & & 40 \\
\hline 4. Mid Cap & & 16 & & & & & & & 16 \\
\hline 5. Large Cap & & 4 & & & & & & & 4 \\
\hline Grand Total & & 209 & 61 & 38 & 5 & 1 & & & 314 \\
\hline
\end{tabular}

United Kingdom (GBP)

Tick Size as a Percentage of Share Price

\begin{tabular}{|c|c|c|c|c|c|c|c|c|c|}
\hline $\begin{array}{l}\text { Market Capitalization } \\
\text { Range (USD) } \\
\end{array}$ & A. $<0.1 \%$ & $\begin{array}{l}\text { B. } 0.1 \% \\
\text { to } 0.5 \% \\
\end{array}$ & $\begin{array}{c}\text { C. } 0.5 \%+ \\
\text { to } 1 \% \\
\end{array}$ & $\begin{array}{l}\text { D. } 1 \%+ \\
\text { to } 2.5 \% \\
\end{array}$ & $\begin{array}{c}\text { E. } 2.5 \%+ \\
\text { to } 5 \% \\
\end{array}$ & \begin{tabular}{|c|} 
F. $5 \%+$ to \\
$10 \%$ \\
\end{tabular} & $\begin{array}{l}\text { G. } 10 \%+ \\
\text { to } 25 \%\end{array}$ & H. $>25 \%$ & $\begin{array}{c}\text { Grand } \\
\text { Total } \\
\end{array}$ \\
\hline 1. Nano Cap & 363 & 89 & 85 & 151 & 16 & 11 & 8 & 9 & 732 \\
\hline 2. Micro Cap & 82 & 61 & 47 & 42 & 7 & 5 & 2 & & 246 \\
\hline 3. Small Cap & 118 & 26 & 9 & 7 & 1 & & & & 161 \\
\hline 4. Mid Cap & 109 & 9 & 1 & 6 & & & & & 125 \\
\hline 5. Large Cap & 39 & & & 1 & & & & & 40 \\
\hline Grand Total & 711 & 185 & 142 & 207 & 24 & 16 & 10 & 9 & 1,304 \\
\hline
\end{tabular}


United States (USD)

Market Capitalization

Range (USD)

1. Nano Cap

2. Micro Cap

3. Small Cap

4. Mid Cap

5. Large Cap

Grand Total
Tick Size as a Percentage of Share Price

Primary listings and common stock/depository receipts only, excludes trusts and funds.

Excludes Chile.

Sources: Weild \& Co., Grant Thornton LLP, exchange regulations, Capital IQ and FactSet 


\section{GLOSSARY OF TERMS}

Adjusted $\mathbf{R}$ squared $\left(\mathbf{R}^{2}\right)$ - The use of an adjusted $R^{2}$ is an attempt to account for the phenomenon of the $R^{2}$ automatically increasing when extra explanatory variables are added to a model by adjusting downward for it. Since it is always less than the coefficient of determination, it is considered to be a more conservative measure.

Aftermarket - The public or secondary trading market for securities after they have been issued.

AUM - Assets under management by an institution.

Bankable spread - The portion of a quoted trading spread that market makers can reasonably rely upon to compensate themselves for their investment in capital, research and sales support. In today's electronic order-driven market, the bankable spread is generally as small as the tick size.

Basis point - One-hundredth of one percent.

Bucket shop - A business that purports to be a stock exchange or business of similar repute, but that actually exists to take side bets, usually for small amounts, on the rise or fall of the prices of stocks, grain, oil, etc. There is no transfer or delivery of the stock or commodities in which customers nominally deal.

Capital formation - The transfer of assets from individuals and institutions to businesses that expand the capacity of those businesses, and, consequently, the capacity of the macroeconomy, to produce goods and services.

Capitalization - Generally used herein to mean "market capitalization," i.e., the total equity market value of a company (total number of shares outstanding multiplied by share price).

Collateralized debt obligation (CDO) - Security backed by a pool of different types of debt. Each type or "tranche" of debt has a different associated maturity and risk.

Collateralized loan obligation (CLO) - Subset of CDOs, backed by commercial loan receivables.

Closed-end fund - A publicly traded investment company that raises a fixed amount of capital via an initial public offering (IPO) and whose shares trade like the shares of a normal corporation.

Coefficient of determination $\left(\mathbf{R}^{2}\right)$ - Commonly referred to as "R-squared," this is the measure of correlation between a security, or group of securities, and a benchmark index or statistical model. The $R^{2}$, whose values typically range from 0 to 1 in linear regression, describes how effective an index or model is at predicting an outcome or 
testing a hypothesis. Generally speaking, the higher the $\mathrm{R}^{2}$, the better the regression line fits the data.

Dark pool - Private trading network that permits institutions to execute orders anonymously. Originally conceived as a way for institutions to trade large orders without impacting the price adversely, dark pools have increasingly become used to execute smaller trades which inhibit the price discovery that would occur normally with "lit" (visible) exchange trades. FINRA is exploring ways to monitor trading in dark pools.

Decimalization - Series of SEC-implemented regulations starting in 1997 that destroyed the economic infrastructure that supported smaller and less liquid public companies.

- New Order Handling Rules in 1997 required dealers to provide investors with their most competitive quotes, laying the groundwork for greater competition between dealers and narrower tick sizes.

- Regulation Alternative Trading Systems (ATS) in 1998 allowed electronic communication networks (ECNs) to link their securities and orders with registered exchanges. It exposed traditional trading venues like NASDAQ to fierce competition by driving down the volume of orders and reducing tick sizes to 3.125 cents.

- Decimalization in 2001 required stocks to be quoted in decimals instead of the historically used fractions. Decimal quoting allowed a minimum tick size of one cent, which resulted in decreased liquidity in already illiquid stocks and greatly increased computer-based and high-frequency trading in already liquid stocks.

- Regulation National Market System (NMS) in 2005 implemented several rules designed to increase competition and improve the performance of U.S. markets for investors. Despite prohibiting sub-penny stock quotes, the SEC allowed certain exceptions for quoting and trade execution in these increments, such as dark pools, algorithmic trading or broker-dealers providing price improvements to a customer order. The exception, unfortunately, became the rule, and many more trades were executed at sub-penny increments, further cementing the erosion of trading spreads and tick sizes.

Depository Trust \& Clearing Corporation (DTCC) - The world's largest clearance, settlement and custody and asset servicing firm for equities, corporate and municipal bonds, government and mortgage-backed securities, money market instruments and over-the-counter derivatives. The DTCC is based in the U.S.

Electronic Communication Network (ECN) - Computerized trading system that facilitates trading of stocks away from stock exchanges.

Electronic order book - List of buy and sell orders that an ECN has in a particular security.

Exchange Traded Fund (ETF) - Public security that tracks the performance of a specific index, basket of assets or commodity. They are similar to index funds, except ETFs trade like ordinary stocks and can be shorted or bought on margin.

Financial Crisis - Also referred to as the "Credit Crisis" and "Global Financial Crisis." Blanket term for a series of events in 2007 and 2008 that triggered the global economic recession of the past several years. It was a crisis of liquidity that had not 
been witnessed in generations, leading to global stock market downturns, collapses of major financial institutions and businesses, and the widespread devastation of consumer wealth.

Global Research Analyst Settlement - In 2003, the SEC, the NYSE, the NASD (now FINRA), the New York Attorney General's Office and the North American Securities Administrators Association announced a joint agreement reached with ten of the largest securities firms to address conflicts between research and investment banking in their businesses. As part of the settlement, these firms agreed to insulate their banking and research departments from each other, to prohibit analysts from being compensated on a particular investment banking transaction, to prohibit investment banking from having any input into research compensation or coverage decisions, and to prohibit research analysts from accompanying investment bankers on pitches and road shows to solicit business or market new issues (including IPOs). Firms were penalized with USD 1.4 billion in collective penalties.

Hedge fund - Private, actively managed fund that can invest long and short, in a variety of instruments and markets, using a variety of strategies. Hedge funds have been exempt from many of the regulations to which other funds are subject, though there has been increasing scrutiny and oversight imposed in recent years.

Heteroscedasticity - In a regression analysis, heteroscedasticity describes a violation of the assumption that the regression residuals are drawn from distributions with the same standard deviation (as opposed to "homoscedasticity," where the regression residuals do not appear to follow a pattern when plotted as a function of the observations of each of the independent variables and are therefore assumed to be drawn from distributions with the same standard deviation).

High Frequency Trading (HFT) - Program-based trading using complex algorithms to make large numbers of trades at high speed.

International Financial Reporting Standards (IFRS) - Set of global accounting standards issued by the International Accounting Standards Board that delineates how transactions should be reported in order to facilitate international comparisons.

International Organization of Securities Commissions (IOSCO) - Association of regulatory organizations for global securities and futures markets, with members from over 100 countries.

Index fund - A mutual fund whose portfolio is designed to match the performance of a market index.

Initial Public Offering (IPO) - A private company's first offering of its shares to investors for public trading.

Large cap - "Large capitalization" stocks are considered by many investors and practitioners to be those with market capitalizations of at least USD 5 billion, though many investors and market practitioners consider the threshold to be at least USD 10 billion .

Microcap - "Microcapitalization" stocks are considered to be those with market capitalizations between USD 100 million and 500 million . 
Midcap - "Mid-capitalization" stocks are generally considered to be those with market capitalizations between USD 2 billion and USD 5 billion .

MiFID - The Markets in Financial Instruments Directive is a law that was enacted in 2004 and took effect in 2007. MiFID was designed to begin the integration of all of the financial markets in the European Union and increase cross-border trading.

MiFID II - The Markets in Financial Instruments Directive II is the European Commission's proposed amendment and extension of MiFID, which aims to improve investor protection, increase transparency of derivatives and other markets, and increase regulation of same.

Multiplier effect - The full impact of a single job created, as measured by the associated economic activity. Enrico Moretti, a professor of economics at the University of California, Berkeley, has written that "for each new high-tech job in a city, five additional jobs are ultimately created outside of the high-tech sector in that city, both in skilled occupations (lawyers, teachers, nurses) and in unskilled ones (waiters, hairdressers, carpenters)."

Multicollinearity - In a multiple regression analysis, multicollinearity describes a situation in which there is strong correlation among the "independent" variables. Multicollinearity can cause anomalous results when trying to establish the effect of a single independent variable.

Mutual fund - An investment company that pools money from numerous investors. Mutual funds sell shares to interested investors directly or through a broker at the net asset value per share (before commissions), and investors can redeem those shares the same way. There is no secondary market for mutual fund shares.

National Venture Capital Association (NVCA) - The venture capital community's primary trade association, representing over 400 firms. The NVCA serves as a resource for venture capital data and advocates for policies that encourage innovation and reward long-term investment.

Network effect - The effect that a user of a product or service has on the value of that product or service to other people. The more people there are who use the product, the more valuable it becomes to everyone else.

Nanocap - "Nanocapitalization" stocks are generally considered to be those with market capitalizations less than USD 100 million .

Residual - In a regression analysis, a residual is the difference between the observed values of the dependent variables and the predicted values of the regression model.

Sarbanes Oxley Act of 2002 - In response to major corporate accounting scandals, Sarbanes-Oxley was implemented in 2002, establishing and enhancing standards for issuers, management and boards of directors, and establishing an oversight board for public accounting firms. While Sarbanes-Oxley did increase compliance costs for issuers, the actual impact on capital formation may have been minimal, as the new Order Handling Rules and Regulation ATS had already damaged spreads and tick sizes several years before Sarbanes-Oxley.

SEC - The U.S. Securities and Exchange Commission. 
Secular - A stock market trend that is long term in nature, generally 5 to 25 years.

Small cap - "Small capitalization" stocks are generally considered to be those with market capitalizations between USD 500 million and 2 billion .

SMEs - Small and medium-sized enterprises. Different countries define these categories differently, but European SMEs are generally considered to employ less than 250 people, while U.S. SMEs are typically considered to have less than 500 employees.

Spread - The difference between the best bid and best offer in a given stock.

Standard residual - In a regression analysis, a standard residual makes the residuals "unitless" by dividing them by their standard deviation, in order to tell how many standard deviations above (if positive) or below (if negative) a data point is from the estimated regression line. Assuming that the data used is normally distributed, $95 \%$ of the measurements should fall within two standard deviations of the mean. Therefore, any predicted values with a standardized residual greater than 2 or smaller than -2 can generally be considered an outlier (i.e., statistically inconsistent with the rest of the data).

Tick size - The minimum increment in which a security can trade. Tick sizes in the U.S. have shrunk from 12.5 cents before the Order Handling Rules and Regulation ATS to just one cent today for stocks greater than or equal to USD 1 per share. 


\section{BIBLIOGRAPHY}

Ahn, H., J. Cai and Y. L. Cheung (2005), "Price clustering on the limit-order book: Evidence from the stock exchange of Hong Kong", Journal of Financial Markets.

Aitken, M. and C. Comerton-Forde (2005), “Do reductions in tick sizes influence liquidity?", Accounting and Finance, Volume 45, Issue 2.

Allen, D. E. and J. Sudiman (2009), "Does tick size change improve liquidity provision? Evidence from the Indonesia stock exchange", School of Accounting, Finance and Economics \& FEMARC Working Paper Series, Edith Cowan University.

Angel, J. J. (1997), "Tick size, share prices, and stock splits", The Journal of Finance, Volume 52, Issue 2.

Arnuk, S. and J. Saluzzi (2012), Broken markets, FT Press.

Beachhead Capital Management (2013), Performance of emerging equity long/short hedge fund managers: 2003-2012.

Bessembinder, H. (2003), "Trade execution costs and market quality after decimalization". The Journal of Financial and Quantitative Analysis, Volume 38, No. 4, Cambridge University Press.

Blundell-Wignall, A. and P. E. Atkinson (2012), "Deleveraging, traditional versus capital markets banking and the urgent need to separate and recapitalise G-SIFI banks", OECD Journal: Financial Market Trends, Issue 1.

Boehmer, E., K. Fong and J. Wu (2012), "International evidence on algorithmic trading", AFA 2013 San Diego Meetings Paper, http://dx.doi.org/10.2139/ssrn.2022034.

Bradley, H. and R. E. Litan (2010), "Choking the recovery: Why new growth companies aren't going public and unrecognized risks of future market disruptions", Ewing Marion Kauffman Foundation, http://dx.doi.org/10.2139/ssrn.1706174.

Chakrabarty, B. and K. H. Chung (2004), "Can sub-penny pricing reduce trading costs?", http://dx.doi.org/10.2139/ssrn.607765.

Chakravarty, S., S. P. Harris and R. A. Wood (2001), "Decimal trading and market impact", http://dx.doi.org/10.2139/ssrn.266877.

Chan, K. C. and C. Hwang (2001), "The impact of tick size on the quality of a pure orderdriven market: evidence from the stock exchange of Hong Kong".

Chung, K. H. (2003), C. Chuwonganant and T. McCormick, "Order preferencing and market quality on NASDAQ before and after decimalization", http://dx.doi.org/10.2139/ssrn.393560. 
Chung, K. H., K. A. Kim and P. Kitsabunnarat (2004), "Liquidity and quote clustering in a market with multiple tick sizes", Journal of Financial Research (forthcoming), http://ssrn.com/abstract=539762.

Cox, J. (2000), "U.S. success draws envy", USA Today, 3 August.

Declerck, F. and D. Bourghelle (2002), "Why markets should not necessarily reduce the tick size", EFMA 2002 London Meetings, http://dx.doi.org/10.2139/ssrn.282909.

Easley, D., M. López de Prado and M. O'Hara (2010), "The microstructure of the 'flash crash': Flow toxicity, liquidity crashes and the probability of informed trading", The Journal of Portfolio Management, Volume 37, No. 2, http://ssrn.com/abstract=1695041.

Egginton, J. F., B. F. and R. A. Van Ness (2013), "Quote stuffing”, http://dx.doi.org/10.2139/ssrn.1958281.

European Commission (2011), Commission Staff Working Paper, "Executive summary of the impact assessment", 20 October, http://ec.europa.eu/internal market/securities/docs/isd/mifid/SEC 20111227 en.pdf.

Federation of European Securities Exchanges (2012), "Tick size regimes", www.fese.be/en/?inc=cat\&id=34.

Goldstein, M. A. and K. A. Kavajecz (2000), "Eighths, sixteenths and market depth: Changes in tick size and liquidity provision on the NYSE", Journal of Financial Economics, Volume 56, No. 1, http://ssrn.com/abstract=979088.

Grant, J. (2009), "LSE bows to tick size pressure as war erupts", Financial Times, 17 June,

Hendershott, T., C. M. Jones and A. J. Menkveld (2010), "Does algorithmic trading improve liquidity?", Journal of Finance, Volume 66, WFA 2008 Paper, http://ssrn.com/abstract=1100635.

Huang, R. D. and H. R. Stoll (2001), "Tick size, bid-ask spreads and market structure", Journal of Financial and Quantitative Analysis, Volume 36, Issue 04.

International Organization of Securities Commissions (2013), "Regulatory issues raised by changes in market structure", Consultation report, March.

Isaksson, M. and S. Çelik (2013), "Who Cares? Corporate Governance in Today's Equity Markets", OECD Corporate Governance Working Papers, No. 8, OECD Publishing.

Johnson, C. W. and L. Williams (2012), "Market commentary: Trends in bond/equities \& trading volume", Piper Jaffray Technical Research, 19 April.

Joint CFTC-SEC Advisory Committee on Emerging Regulatory Issues (2011), "Recommendations regarding regulatory responses to the market events of May 6 , 2010".

JP Morgan (2011), "Rise of cross-asset correlations", www.cboe.com/Institutional/JPMCrossAssetCorrelations.pdf. 
Kay, J. (2012), "The Kay review of UK equity markets and long-term decision making", http://www.bis.gov.uk/assets/biscore/business-law/docs/k/12-917-kay-review-of-equitymarkets-final-report.pdf.

Kim, S. and D. Murphy (2013), "The impact of high-frequency trading on stock market liquidity measures", http://ssrn.com/abstract=2278428.

Kim, W. (2011), "Korea's capital market promotion policies: IPOs and other supplementary policy experiences", http://dx.doi.org/10.2139/ssrn.2194337.

Kirilenko, A. A., A. S. Kyle, M. Samadi and T. Tuzun (2011), "The flash crash: The impact of high-frequency trading on an electronic market", http://dx.doi.org/10.2139/ssrn.1686004.

Linton, O. and M. O'Hara (2011), "The impact of computer trading on liquidity, price efficiency/discovery and transaction costs", The Future of Computer Trading in Financial Markets, Working paper, UK Government Office for Finance.

Moretti, E. (2013), The new geography of jobs, New York.

Struyven, D. (2008), "The Battle between the Bombay Stock Exchange and the National Stock Exchange".

The Trade News (2011), "NYSE Euronext tick size move 'bad' for market structure".

U.S. Securities and Exchange Commission (2012), "The SEC report to Congress on decimalization".

Van Kervel, V. (2012), "Liquidity: What you see is what you get?", http://dx.doi.org/10.2139/ssrn.2021988.

Weild, D. and E. Kim (2008), "Why are IPOs in the ICU?”, Grant Thornton LLP, www.gt.com/staticfiles/GTCom/files/GT\%20Thinking/IPO\%20white\%20paper/Why\%20 are\%20IPOs\%20in\%20the\%20ICU 11 19.pdf.

Weild, D. and E. Kim (2009), "A wake-up call for America”, Capital Markets Series, Grant Thornton LLP, http://www.gt.com/staticfiles/GTCom/Public\%20companies\%20and\%20capital\%20mar kets/gt wakeup call .pdf.

Weild, D. and E. Kim (2010), "Market structure is causing the IPO crisis—and more", Capital Markets Series, Grant Thornton LLP, www.gt.com/staticfiles/GTCom/Public\%20companies\%20and\%20capital\%20markets/ Files/IPO\%20crisis\%20-\%20June\%202010\%20-\%20FINAL.pdf.

Weild, D., E. Kim and L. Newport (2012), "The trouble with small tick sizes", Capital Markets Series, Grant Thornton LLP, www.sec.gov/info/smallbus/acsec/acsecbackgroundmaterials-090712-weild-article.pdf.

Werner, I. M. (2003), "Execution quality for institutional orders routed to NASDAQ dealers before and after decimals", Dice Center Working Paper No. 2003-25, http://dx.doi.org/10.2139/ssrn.463061.

Williamson, C. (2013), Pensions \& Investments, 4 February. 
Zhang, F. (2010), "High-frequency trading, stock volatility and price discovery", Yale School of Management, http://dx.doi.org/10.2139/ssrn.1691679.

Zweig, J. (2011), "Why a legendary market skeptic is upbeat about stocks", Wall Street Journal, 10 September. 
APPENDIX 


\section{Country by Country IPO Effectiveness Has Changed Over Time}

Domestic IPOs $\geq \$ 5$ Million

$\mathrm{x}=$ Average GDP (USD in Billions); $\mathrm{y}=$ Domestic Deals per $\$ 100$ Billion USD of GDP; $z=$ Number of Domestic Deals

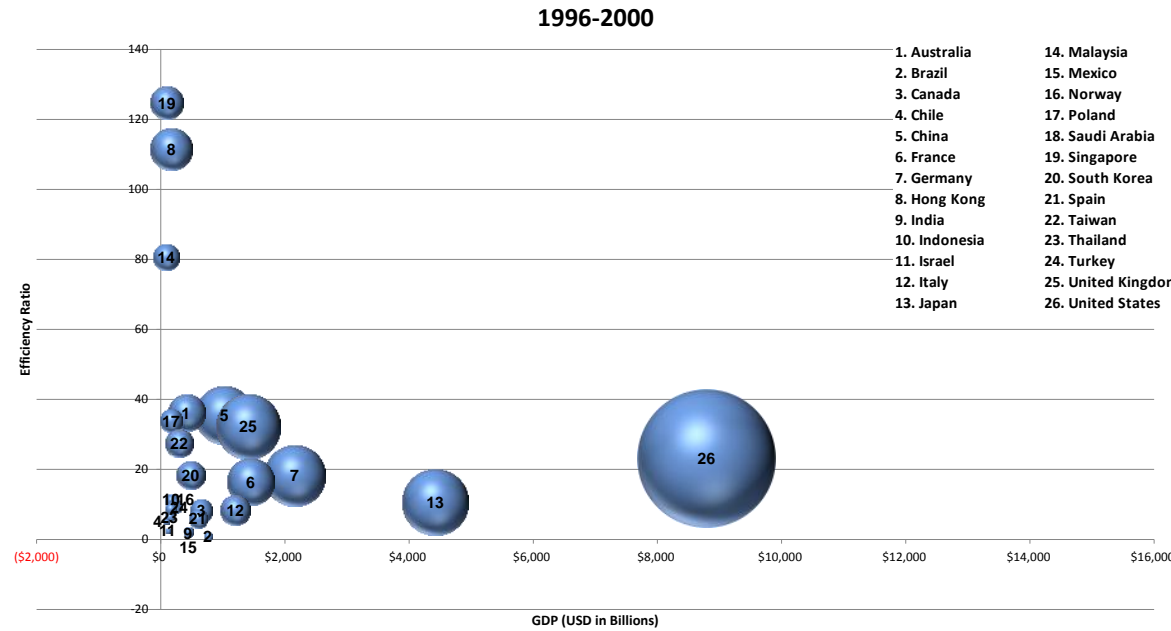

2001-2005

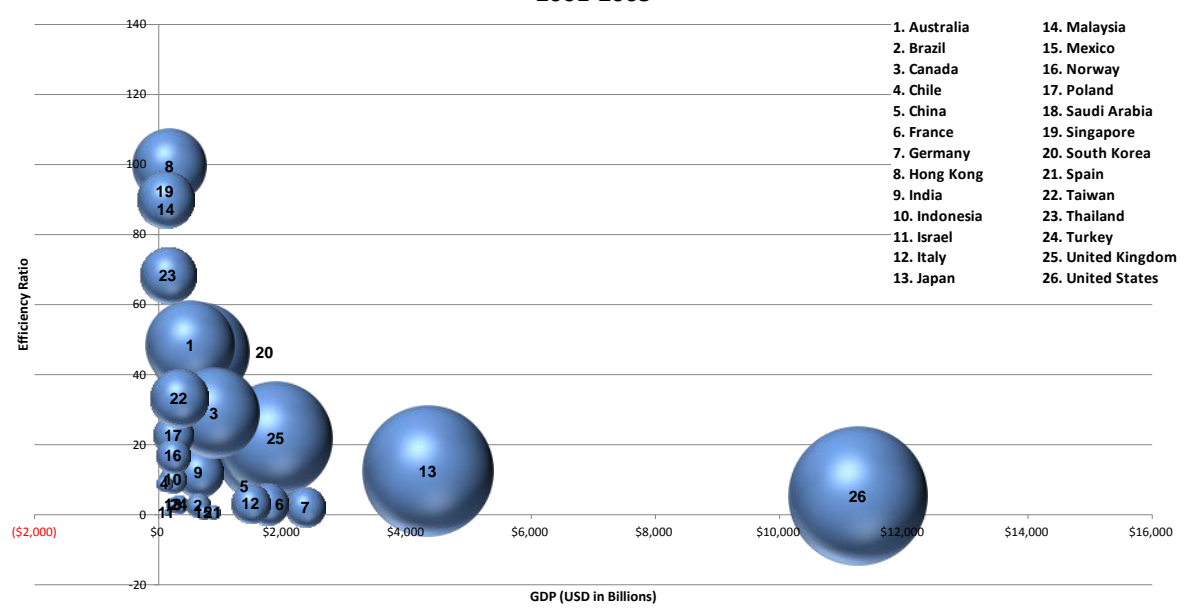

2008-2012

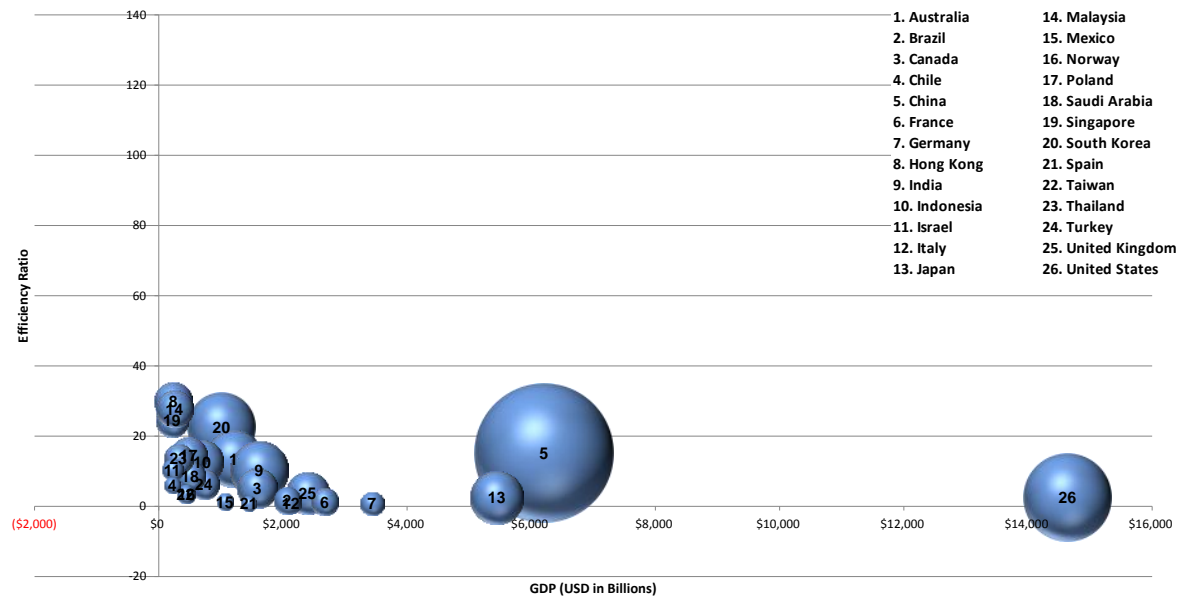

Includes domestic corporate IPOs with a deal value of at least $\$ 5$ million (USD) as of Dec. 31, 2012, excluding funds, LPs, SPACs, REITs and other trusts.

2012 estimate for gross domestic product (GDP).

Sources: Weild \& Co., Grant Thornton LLP, Dealogic, the World Bank and The World Factbook 


\section{Country Ranking by Number of IPOs $\geq \$ 5$ Million 2008-2012 \\ 2008-2012}

1. China, $\$ 8.25$ trillion GDP

3. Hong Kong, \$258 billion GDP

5. United Kingdom, $\$ 2.434$ trillion GDP

7. India, \$1.947 trillion GDP

9. Canada, \$1.77 trillion GDP

11. Indonesia, \$894.9 billion GDP

13. Malaysia, $\$ 307.2$ billion GDP

15. Saudi Arabia, $\$ 657$ billion GDP

16. Thailand, $\$ 377$ billion GDP

19. Brazil, $\$ 2.425$ trillion GDP

- 21. Italy, \$1.98 trillion GDP

21. Taiwan, $\$ 466.1$ billion GDP

-25. Chile, $\$ 268.3$ billion GDP

27. Bangladesh, $\$ 118.7$ billion GDP

27. United Arab Emirates, $\$ 361.9$ billion GDP

31. Jordan, $\$ 31.35$ billion GDP

31. Russian Federation, \$1.954 trillion GDP

35. Denmark, $\$ 309.2$ billion GDP

36. Sri Lanka, $\$ 59.77$ billion GDP

39. Colombia, $\$ 365.4$ billion GDP

39. Oman, $\$ 79.97$ billion GDP

43. Kenya, \$41.84 billion GDP

43. Vietnam, $\$ 137.7$ billion GDP

46. Egypt, $\$ 255$ billion GDP

46. Pakistan, $\$ 230.5$ billion GDP

50. Botswana, $\$ 17.64$ billion GDP

50. Iran, $\$ 483.8$ billion GDP

50. Netherlands, $\$ 770.2$ billion GDP

50. Romania, \$171.4 billion GDP

50. Zambia, \$20.68 billion GDP

60. Ghana, $\$ 40.12$ billion GDP

60. Qatar, $\$ 184.6$ billion GDP

65. Algeria, \$206.5 billion GDP

65. Bahrain, $\$ 26.51$ billion GDP

65. Cote D'Ivoire (Ivory Coast), \$24.27 billion GDP

65. Estonia, \$21.42 billion GDP

65. Kazakhstan, $\$ 200.6$ billion GDP

65. Luxembourg, $\$ 55.29$ billion GDP

65. Maldives, $\$ 1.424$ billion GDP

65 . Mauritius, $\$ 11.93$ billion GDP

65. Portugal, $\$ 210.6$ billion GDP

65. Uganda, $\$ 20.46$ billion GDP

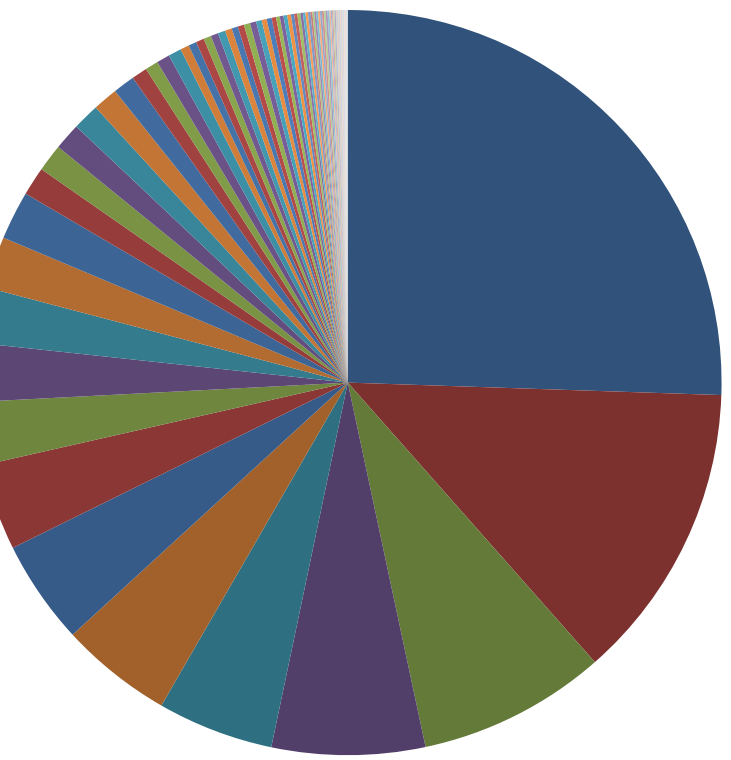

Sorted by Country

Ranking

Sources: Weild \& Co., Grant Thornton LLP, Dealogic and The World Factbook Includes domestic and foreign corporate IPOs with a deal value of at least $\$ 5$ million USD between Jan. 1, 2008 and Dec. 31, 2012, excluding funds, LPs, SPACs, REITs and other trusts. Gross domestic product (GDP) in U.S. dollars as of 2012 (estimate). 


\title{
Country Ranking by Number of IPOs Between $\$ 5$ Million and $\$ 50$ Million 2008-2012
}

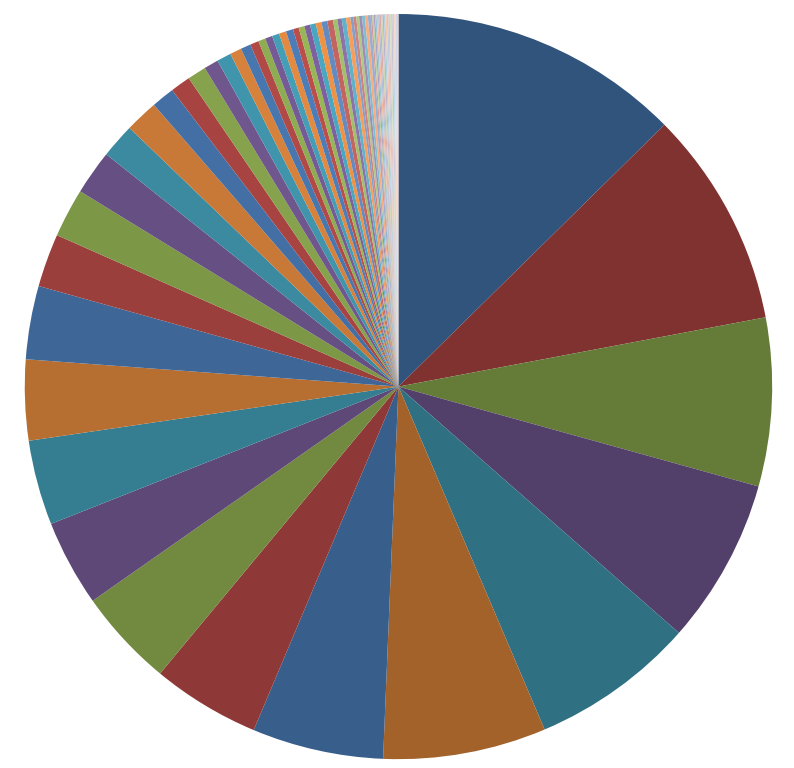

\author{
Sorted by Country \\ Ranking
}

Sources: Weild \& Co., Grant Thornton LLP, Dealogic and The World Factbook Includes domestic and foreign corporate IPOS with a deal value between $\$ 5$ million and \$50 million USD between Jan. 1, 2008 and Dec. 31, 2012, excluding funds, LPs, SPACS, REITs and other trusts.

Gross domestic product (GDP) in U.S. dollars as of 2012 (estimate).

1. South Korea, $\$ 1.151$ trillion GDP

3. China, $\$ 8.25$ trillion GDP

- 5. Japan, $\$ 5.984$ trillion GDP

7. United Kingdom, $\$ 2.434$ trillion GDP

9. Singapore, $\$ 267.9$ billion GDP

11. Malaysia, $\$ 307.2$ billion GDP

13. Indonesia, $\$ 894.9$ billion GDP

15. France, $\$ 2.58$ trillion GDP

17. Germany, $\$ 3.367$ trillion GDP

19. Taiwan, $\$ 466.1$ billion GDP

21. Saudi Arabia, $\$ 657$ billion GDP

22. Jordan, $\$ 31.35$ billion GDP

- 25. Sri Lanka, $\$ 59.77$ billion GDP

27. Chile, $\$ 268.3$ billion GDP

27. Morocco, $\$ 97.17$ billion GDP

-27. Syria, $\$ 64.7$ billion GDP

32. New Zealand, $\$ 166.9$ billion GDP

32. Russian Federation, $\$ 1.954$ trillion GDP

32. Sweden, $\$ 520.3$ billion GDP

39. Botswana, \$17.64 billion GDP

39. Romania, $\$ 171.4$ billion GDP

43. Belgium, $\$ 476.8$ billion GDP

43. Kenya, $\$ 41.84$ billion GDP

43. Oman, $\$ 79.97$ billion GDP

43. Zambia, $\$ 20.68$ billion GDP

50. Brazil, \$2.425 trillion GDP

50. Colombia, $\$ 365.4$ billion GDP

50. Czech Republic, $\$ 193.5$ billion GDP

50. Iceland, $\$ 13.55$ billion GDP

50. Kuwait, \$174.6 billion GDP

50. Malawi, $\$ 4.49$ billion GDP

50. Malta, $\$ 8.415$ billion GDP

50. Nigeria, $\$ 272.6$ billion GDP

50. Rwanda, \$6.95 billion GDP
- 2. Australia, $\$ 1.542$ trillion GDP

4. Hong Kong, \$258 billion GDP

6. India, \$1.947 trillion GDP

- 8. United States, $\$ 15.65$ trillion GDP

10. Poland, $\$ 470.4$ billion GDP

12. Canada, $\$ 1.77$ trillion GDP

-14. Turkey, $\$ 783.1$ billion GDP

16. Thailand, $\$ 377$ billion GDP

18. Israel, $\$ 246.8$ billion GDP

20. Italy, $\$ 1.98$ trillion GDP

22. Bangladesh, $\$ 118.7$ billion GDP

24. Spain, $\$ 1.34$ trillion GDP

- 26. United Arab Emirates, $\$ 361.9$ billion GDP

-27. Denmark, $\$ 309.2$ billion GDP

27. Norway, $\$ 499.8$ billion GDP

32. Bulgaria, $\$ 50.81$ billion GDP

32. Pakistan, $\$ 230.5$ billion GDP

32. South Africa, $\$ 390.9$ billion GDP

32. Vietnam, $\$ 137.7$ billion GDP

39. Philippines, $\$ 240.7$ billion GDP

39. Tunisia, $\$ 44.7$ billion GDP

43. Ghana, $\$ 40.12$ billion GDP

43. Lithuania, $\$ 41.22$ billion GDP

43. Tanzania, $\$ 27.98$ billion GDP

50. Algeria, $\$ 206.5$ billion GDP

50. Cambodia, $\$ 14.25$ billion GDP

50. Cyprus, $\$ 22.45$ billion GDP

50. Estonia, \$21.42 billion GDP

50. Ireland, $\$ 204.7$ billion GDP

50. Luxembourg, $\$ 55.29$ billion GDP

50. Maldives, $\$ 1.424$ billion GDP

50. Mauritius, $\$ 11.93$ billion GDP

50. Peru, $\$ 200.3$ billion GDP

50. Switzerland, $\$ 622.9$ billion GDP 


\section{Country Ranking by Number of IPOs $>$ \$50 Million 2008-2012}

1. China, $\$ 8.25$ trillion GDP - 3. Hong Kong, \$258 billion GDP 5. India, \$1.947 trillion GDP

7. South Korea, \$1.151 trillion GDP 9. Brazil, $\$ 2.425$ trillion GDP -11. Australia, \$1.542 trillion GDP 13. Japan, $\$ 5.984$ trillion GDP 15. Germany, \$3.367 trillion GDP 17. Norway, $\$ 499.8$ billion GDP

19. Thailand, $\$ 377$ billion GDP 20. Philippines, $\$ 240.7$ billion GDP

23. Italy, \$1.98 trillion GDP

-25. Sweden, $\$ 520.3$ billion GDP

25. United Arab Emirates, $\$ 361.9$ billion GDP

29. Colombia, $\$ 365.4$ billion GDP

-29. Nigeria, $\$ 272.6$ billion GDP

29. Switzerland, $\$ 622.9$ billion GDP

35. Oman, $\$ 79.97$ billion GDP

35. New Zealand, $\$ 166.9$ billion GDP

35. Egypt, \$255 billion GDP

40. Kenya, $\$ 41.84$ billion GDP

40. Iran, \$483.8 billion GDP

44. Kuwait, $\$ 174.6$ billion GDP

44. Argentina, $\$ 474.8$ billion GDP

44. Peru, $\$ 200.3$ billion GDP

51. Slovenia, $\$ 45.42$ billion GDP

51. Palestinian Territory, Occupied, $\$ 6.641$ billion GDP

51. Portugal, $\$ 210.6$ billion GDP

51. Uganda, \$20.46 billion GDP

51. Zambia, $\$ 20.68$ billion GDP

51. Austria, \$391.5 billion GDP

51. Cote D'Ivoire (Ivory Coast), \$24.27 billion GDP

51. Kazakhstan, $\$ 200.6$ billion GDP

\section{Sorted by Country \\ Ranking}

Sources: Weild \& Co., Grant Thornton LLP, Dealogic and The World Factbook Includes domestic and foreign corporate IPOs with a deal value of at least $\$ 50$ million USD between Jan. 1, 2008 and Dec. 31, 2012, excluding funds, LPs, SPACs, REITs and other trusts. Gross domestic product (GDP) in U.S. dollars as of 2012 (estimate). 